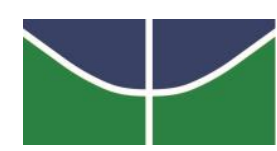

Universidade de Brasília

Instituto de Letras

Departamento de Teoria Literária e Literaturas

Programa de Pós-Graduação em Literatura

Marcos Vinicius Caetano da Silva

Brasília - DF 
Ficha catalográfica elaborada automaticamente, com os dados fornecidos pelo(a) autor(a)

Sertão e Savana: forma literária e processo

histórico em contos de Bernardo Élis e de Mia Couto / Marcos Vinicius Caetano da Silva; orientador Edvaldo Aparecido Bergamo. -- Brasília, 2017. $152 \mathrm{p}$.

Dissertação (Mestrado - Mestrado em Literatura) -Universidade de Brasília, 2017.

1. Literatura comparada. 2. Processo formativo. 3. Pós-colonialismo. 4. Mia Couto. 5. Bernardo Élis. I. Bergamo, Edvaldo Aparecido, orient. II. Título. 
Marcos Vinicius Caetano da Silva

SERTÃO E SAVANA: FORMA LITERÁRIA E PROCESSO HISTÓRICO EM CONTOS DE BERNARDO ÉLIS E DE MIA COUTO

Dissertação apresentada ao Programa de

Pós-Graduação em Literatura do Departamento de Teoria Literária e Literaturas - TEL do Instituto de Letras - IL da Universidade de Brasília - UnB como requisito parcial para a obtenção do título de Mestre em Literatura.

Orientador: Prof. Dr. Edvaldo Aparecido Bergamo

Brasília

2017 


\title{
SERTÃO E SAVANA: FORMA LITERÁRIA E PROCESSO HISTÓRICO EM CONTOS DE BERNARDO ÉLIS E DE MIA COUTO
}

\author{
Dissertação apresentada ao Programa de \\ Pós-Graduação em Literatura do \\ Departamento de Teoria Literária e \\ Literaturas - TEL do Instituto de - IL Letras \\ da Universidade de Brasília - UnB como \\ requisito parcial para a obtenção do título de \\ Mestre em Literatura.
}

\footnotetext{
Prof. Dr. Edvaldo Aparecido Bergamo - TEL/UnB (Orientador e Presidente da Banca)
}
Prof. Dr. Rogério Max Canedo Silva (Membro Externo)

Profa. Dra. Ana Claudia da Silva (Membro Interno)
Prof. Dr. Ana Laura dos Reis Corrêa (Membro Suplente)


Meu padrinho era um homem cheio de histórias!! Seus causos foram situações que ele contava de diferentes maneiras, diversas vezes! Havia fatos que o levaram além da vivência de mecânico, para uma cidade nova e moderna chamada Brasília. Houve também as situações em que suas estórias se mostraram a sua sobrevivência durante o regime militar, mas que ocuparam sua oficina até que esta se fechou. Exilado na vida doméstica em seus últimos anos, numa cidade interiorana, sua voz se calou diante daqueles que sempre o oprimiram, até que desapareceu. Desapareceram muitas dessas estórias que compõem a história do homem mais honrado que pude conhecer e ter como padrinho e avô. Dia 6 de setembro de 2016 morreram várias dessas estórias com ele. Seu coração, entretanto, será memória eterna. A você, padrinho, dedico este pequeno trabalho. 


\section{AGRADECIMENTOS E REVERÊNCIAS}

Quisera eu pôr os tempos, em sua mansa ordem, conforme o processo de escrita do que se apresenta aos seus olhos, querido leitor, mas minhas lembranças desobedecem, entre a vontade de nada serem e o intuito de me sequestrarem do presente. Se volto a mim mesmo ao pensar no desenvolvimento deste trabalho, me esqueço ao lê-lo em seu tempo retilíneo e objetivo.

Este sonho mostra a esperança, a mesma que me apontaram dois jovens moçambicanos em terras soteropolitanas, de pôr o tempo em seu lugar e me levar ao distante experienciar proporcionado pela aventura de escrever.

A escrita começa por um ponto indefinido no tempo, no espaço, habitado pelos meus antepassados. Se pude encontrar o ar necessário ao viver, à palavra e à escrita desta, agradeço profundamente a eles. Em especial, reverencio minha avó, Maria Lino da Silva, cujo amor e carinho são inesquecíveis. Também reverencio o meu padrinho e avô, José Mendes Neto, que sempre me apoiou em meus projetos e hoje está torcendo por mim lá do céu. Agora, dada a ação de contar, enumero as minhas grandes referências primárias e ainda presentes: minha mãe, Edilamar, que sempre apoiou meus projetos e realizações, e sempre viu o eterno menino que sou mesmo enquanto homem; meu pai, Hélio, que sempre me proporcionou o melhor em termos de educação e qualidade de vida, além de ser exemplo de caráter e moral. Se contarmos em três nosso núcleo familiar, darei pela falta de meus irmãos, Luciano e Bárbara, companheiros de aventuras e apoio para quaisquer adversidades que nos vêm. A minha avó, Lilia, e a minha prima, Paula, em nome de seu amor registro aqui o meu, em retorno, e a minha gratidão.

Se também pude contar não só em números, mas em abraços e tapas nas costas, é importante também agradecer aos amigos que, embora contando nos dedos e substantivos próprios, sempre me apoiaram dentro e fora desta jornada, de modo que aprendemos juntos. Jonatas Rafael Alvares, Fernando Araujo, Victor Augusto Martins Ribeiro, Petterson Rodrigues, Érica Calil, Paula Alves, Paula Baron, Indira Magalhães, Diego Alves, Raíssa Baeta, Rodrygo Prado, Murilo Maximiano, Kamila Barreto, Raylane Stephany, Denilson Alves, 
Jadson Reis, Jonatan Santos, Sávio Ribeiro da Cruz, Lucas Sousa, Wellington Camargo, Camila Carvalho, Alex Machado, Marcos Vinícios Martins (Xará), Mikael Rocha, Fabiana Camargo, Mariana Bernardes e Vagner Luíz da Fonseca. Ainda, se pude contar com esses amigos fora de minha jornada, pude também abrir os horizontes de minha tarefa durante o Mestrado e trazer para minha vida amigos como Anna Isabel Freire, Elisabete Barros, Janara Laíza, Ely Lara, Rosa Alda, Allan Brasileiro, Rosângela Lopes, Roberto Medina, Francisco Alves, Amanda Lucy, Lívia Barreto, Dâmaris Bacon, João Paulo Ferreira, Kárita Borges, Daniele Rosa, Fabiano Vale, Luciana Carvalho, Dapheny Feitosa, Isabela Silva, Luísa Leite, Pedro Couto e Priscila Nayade. Muito obrigado a todos. Também registro aqui a minha gratidão ao Rogério Max Canedo, pela amizade, cordialidade e conselhos que só podem vir de um amigo que me quer muito bem. Penso ser maravilhoso Deus ter oportunizado nossos encontros e que nossas amizades se estabelecessem.

Se hoje posso pensar sobre o papel da literatura enquanto professor, também devo agradecer aos professores do Departamento de Teoria Literária e Literaturas da Universidade de Brasília por me proporcionarem, desde a Graduação, uma boa formação na área que pretendi estudar, como os professores Gilson Sobral, Hermenegildo Bastos, Maria Isabel Edom Pires, Anderson da Mata, Sara Almarza e Lúcia Helena Marques Ribeiro. Também, aos grupos de pesquisa dos quais faço parte, "Literatura e Modernidade Periférica" e "Mayombe - Literatura, História e Sociedade", que ainda fazem de suas discussões reflexões essenciais a esse trabalho e à minha formação acadêmica.

Cabe registrar um agradecimento especial a quatro professores muito importantes durante o meu caminho enquanto pesquisador. Primeiro, ao professor Alexandre Pilati, que se mostrou sempre acessível e provocador de discussões profícuas, tendo me convidado para sua disciplina de "Literatura e Sociedade no Brasil", mesmo quando ainda eu era estudante da Graduação. Segundo, à professora Ana Laura dos Reis Corrêa, por ter me introduzido e acolhido no início de minhas atividades acadêmicas junto ao grupo de pesquisa "Literatura e Modernidade Periférica", e também por incentivar a rebeldia e o inconformismo numa sociedade em constante transformação. Terceiro, à professora Ana Claudia da Silva, pela sua singular e preciosa amizade, sua 
disposição em me emprestar livros essenciais a este trabalho; por me apoiar em meus projetos, por ter me orientado em meu terceiro Projeto de Iniciação Científica (ProlC), me introduzido no universo das literaturas africanas e também por ter me incluído no grupo Mayombe. Quarto, com uma grande e respeitosa reverência, registro o meu profundo agradecimento ao professor Edvaldo Bergamo, meu admirável orientador, cuja orientação se estende desde o meu primeiro e o meu segundo ProlC's até a realização deste trabalho. Muito obrigado pela paciência, dedicação e compromisso que são marcas de seu exemplar profissionalismo, modelo inspirador para o profissional que almejo me tornar.

Sei que não posso somente me pautar pelo destino, mas as veredas deste trabalho tocaram as margens do amigo Dércio Braúna, cujo contato começou quando ele se disponibilizou a me enviar suas publicações relacionadas a Mia por correio. Muito obrigado, Dércio!

As veredas deste trabalho também me levaram a sertões e uma África distantes, que me fizeram um ser de fronteira entre Brasil e Moçambique. A começar pelos contatos com Jorge Mateus e Nilton Mungamba em Salvador, que me fizeram perceber a magia ao estudar a literatura de Moçambique, esse país maravilhoso. Ao professor Nataniel N'gomane, que me recepcionou em Maputo com muita alegria. Ao Ivo e à Marij Zwart, que me fizeram sentir em casa em Maputo. Ao Porfílio, ao Rui e ao Mateus, que me mostraram a importância da rádio em Moçambique. Ao professor Aurélio Cuna, pelos diálogos frutíferos deste e de futuros trabalhos. Aos escritores da AEMO Associação de Escritores Moçambicanos, que me receberam com bastante eloquência e disponibilidade para diálogo. Ao Mia Couto, com quem, mesmo diante de tantas dificuldades, pude ter contato para entrevista e agradecimentos. Sem Moçambique não os teria conhecido, muito menos sem a obra de Mia. Muito obrigado a todos.

Ao escritor Bernardo Élis, que faz parte de minha formação enquanto pesquisador e se mostra cada vez mais vivo por me permitir enxergar o Brasil hoje por meio de sua literatura.

À indonésia Muziatun Mukadji, amiga que me ajudou a firmar o meu compromisso para com a academia e para com as minhas produções em Osaka, Japão. Obrigado, Muziatun! 
Ao Leonardo Martins, amigo cuja confiança e cumplicidade se mostraram presentes não só durante o processo de elaboração e correção desta, mas também durante a minha vida. Obrigado, Léo!

À CAPES, por ter me disponibilizado uma bolsa de estudos que me possibilitou a realização deste trabalho.

Sem desejar dar por finalizado o ato de contar, apesar do limite entre as linhas, palavras e sentimentos incontáveis, acabo por registrar aqui o apoio incondicional, terno e compreensivo de Danilo.

A todos, o meu muito obrigado. 

[...] a totalidade do real só pode ser apreendida (gradualmente) por nós quando a dialética objetiva de fenômeno e essência e a dialética subjetiva de nossa penetração na essência são concebidas como indissoluvelmente ligadas uma à outra.

LUKÁCS, György. "A característica mais geral do reflexo lírico". In: Arte e sociedade: escritos estéticos 1932-1967. Rio de Janeiro: Editora UFRJ, 2011. p. 247.

[...] quanto mais o homem livre que pensa se imbui da realidade trágica do subdesenvolvimento, mais ele se imbui da aspiração revolucionária - isto é, do desejo de rejeitar o jugo econômico e político do imperialismo e de promover em cada país a modificação de estruturas internas, que alimentam a situação de subdesenvolvimento.

CANDIDO, Antonio. "Literatura e subdesenvolvimento". In: $A$ educação pela noite e outros ensaios. São Paulo: Ática, 1987. p.154.

O presente está cheio de passado e cheíssimo do futuro.

Leibnitz

Por conseguinte, quer para os que colonizaram quer para os que foram colonizados, revisitar as criações de espírito que têm a ver não só com um determinado segmento da história que os ligou, como também com todo um imaginário que subsiste sob formas mais ou menos elaboradas, mais ou menos dissimuladas, torna-se um imperativo que tem tanto de moral como de pedagógico.

NOA, Francisco. Império, mito e miopia: Moçambique como invenção literária. São Paulo: Editora Kapulana, 2015. p. 31. 



\section{Resumo:}

O trabalho apresenta uma leitura comparativa de contos selecionados do escritor brasileiro Bernardo Élis (1915-1997) e do autor moçambicano Mia Couto (1955), considerando como fundamentos da análise crítica as conformações dialéticas campo e cidade, litoral e sertão, mito e religiosidade, razão e loucura, para figurar os impasses da formação nacional do Brasil e de Moçambique. Esses enfoques contrastivos revelam a complexidade dos dilemas históricos dos países em causa, apreendidos na forma artística do conto, de modo a problematizar literariamente os desafios oriundos do subdesenvolvimento e do antigo domínio colonial: um passado que continua a repercutir no presente de tais nações periféricas como história viva.

Palavras-Chave: Bernardo Élis; Mia Couto; Brasil; Moçambique; contos; campo e cidade; litoral e sertão; mito e religiosidade; razão e loucura; (des)colonização e formação nacional. 


\begin{abstract}
:
This paper presents a comparative analysis of selected short stories of the brazilian writer Bernardo Elis (1915-1997) and of the mozambican writer Mia Couto (1955), considering the acknowledgements of the country and the city, the shore and the hinterland, the myth and the religiosity, the reason and the madness as arguments that reveal the complexities of historic dilemmas of refered countries seized into art form of short story as a way to question the literature about the challenges originated from underdevelopment and from old colonial domain: a past that keeps resounding at these peripheral nations at current time as living History.
\end{abstract}

Keywords: Bernardo Elis; Mia Couto; Brazil; Mozambique; short stories; the country and the city; the shore and the hinterland; the myth and the religiosity; the reason and the madness; (de)colonization and national formation. 


\section{Sumário}

"O mundo voa e apenas o poeta faz companhia ao chão": primeiras palavras molhadas.

1. "Já houve até quem visse anjos - muitos anjos - voando nas asas dos pirilampos": sobre o conto

1.1. "No oculto do ventre, o feto se explica como o Homem": a propósito da teoria do conto

1.2. "Hoje, como conheço história do Brasil, mudei a data de meus anos, que é o dia mais triste do mundo": sobre o conto no Brasil 36

1.3. "Eu tive um país pequeno, tão pequeno, que não cabia no mundo": sobre o conto em Moçambique

2. "Até hoje: meu avô vai chispado no Ford do filho, mas vê um carro de bois, manda parar e desce": entre o arcaico e o moderno - conexões índicoatlânticas

2.1. "Só quero lembrar se o tempo for todo meu": a relação com o império51

2.2. "Foi em Goiás que se deu, faz tempo, meu avô me contava": o Brasil de Bernardo Élis. 55

2.3. "Dentro do guerreiro vivia, eterna, a guerra": o Moçambique de Mia Couto 67

3. "Daqui dois homens atiraram-se lá embaixo: um morreu - orai por ele, o outro pede esmola": a notação espacial no conto 81

3.1. "Dos caprinos aprenderam: em qualquer nada, inventam os mais vastos pastos": a dialética campo e cidade. 83

3.2. "Amanhã tudo vai começar de novo": a dialética litoral e sertão 96

3.3. "Sobre o último antigamente a varanda perdura": literatura, sociedade e outros cenários. 106

4. "E a voz escorre dolorida num tom evocativo de remorso mordida de desespero milenário e religioso": literatura e história em movimento ............. 109

4.1. "E Irei pelos teus olhos, até o mundo voltar a ter princípio": mito e religiosidade em profusão 113

4.2. "Parece haver fantasma de Bandeiras passeando pelas ruas estreitas e sombrias": razão e loucura em tensão

4.3. "Agora, resta um único desfecho: de novo, acordar por dentro"........ 130 "Com lâmina de enxada a palavra fere o tempo: decepa o cordão umbilical do que pode ser um chão nascente": considerações finais 133

Referências bibliográficas 141

ANEXO I 149 



\section{"O mundo voa e apenas o poeta faz companhia ao chão"1: primeiras palavras molhadas}

Como fazia anualmente após a primeira chuva, Rosa pela madrugada havia plantado todo o quintal, como se fosse uma roça do sertão. Perto do canto do muro estava encostada a enxada, pesada de barro fresco, o cabo também enlameado, dando a impressão de que Rosa andara revolvendo a terra com as mãos.

Em cada cova viam-se nitidamente os sinais dos pés de Rosa, aqueles pés selvagens, com o dedão fortemente afastado, grosso, rude. Ela havia pisoteado as covas depois de plantadas. As chancas estavam claras no barro mole e peganhento de humo. As pegadas eram visíveis também nas lajes da escada que dava do quintal para a cozinha, onde ficara a marca do dedão esparramado, sujo de lama; prosseguiam como que latejantes pelo chão batido da cozinha, atravessavam a varanda que era de tábuas, ganhavam o corredor que era também de lajes, e daí pegavam a calçada da frente da casa, quase apagadas já, aprofundando-se a seguir sobre os tenros e quase transparentes brotinhos de capim que recobriam o largo como uma casimira das boas, para enfim se perderem na imensidão do largo rebrotado e se reverdecendo.

No quarto de Rosa, dependurado de um torno atrás da porta, estava um vestido velho; no chão, perto da cama, descansava o par de chinelos. Os chinelos eram grosseiros, fabricação de Neca. No couro amarelo que conservava as mossas dos dedos brutais da mulher, estavam calcados os sinais fisionômicos de Rosa. O chinelo parece que escutava, parece que esbarrara ali apenas o momento bastante para recobrar alento e a seguir romper viagem rumo a um ponto muito distante que o estava chamando.

ÉLIS, Bernardo. "Rosa". In: Veranico de Janeiro. Goiânia: ICBC, 2006. p.89.

${ }^{11}$ Estrofe retirada do poema "Tradutor de chuvas", do livro homônimo de Mia Couto publicado em 2011. 

Edward Said (2011) diz ser a cultura elemento central na dominação colonial, notadamente em relação à complexa dinâmica que envolve colônia e metrópole como estrutura imperial (p. 39), com reflexos no tratamento concernente à história e à literatura.

Esse processo também atinge a vida literária, no sentido de exigir uma nova concepção de Weltliteratur (CHEVRIER, 2004, p. 254), cujos modelos não se subordinem às antigas ideias ocidentais e hegemônicas de literatura comparada. Também é preciso reconhecer a necessidade de "reinterpretar os cânones à luz de textos cuja posição dentro dessa cultura não foi suficientemente vinculada e avaliada de acordo com a expansão europeia" (SAID, 2011, p. 115). Essa constante torna-se cada vez mais premente à medida que a sociedade contemporânea se internacionaliza, determinando transformações que:

Em lugar das velhas necessidades, satisfeitas pela produção nacional, surgem necessidades novas, que para serem satisfeitas exigem os produtos das terras e dos climas mais distantes. Em lugar da antiga autossuficiência e do antigo isolamento local e nacional, desenvolve-se em todas as direções um intercâmbio universal, uma universal interdependência das nações. $E$ isso tanto na produção material quanto na intelectual. Os produtos intelectuais (die geistigen Erzeugnisse) de cada nação tornam-se patrimônio comum. A unilateralidade e a estreiteza nacionais tornam-se cada vez mais impossíveis, e das numerosas literaturas nacionais e locais forma-se uma literatura mundial (MARX; ENGELS, 2011, p. 44).

Essa "obrigação", destacada por Marx e Engels na obra Manifesto do partido comunista (1848), não só coloca as produções individuais locais e nacionais numa mesma classificação mercadológica, mas também submete todas as nações "a ingressarem no que ela [a burguesia] chama de civilização, isto é, a se tornarem burguesas. Numa palavra, cria um mundo à sua imagem e semelhança" (MARX; ENGELS, 2011, p. 45). A subordinação do campo à cidade, dos países atrasados às nações civilizadas, do oriente ao ocidente, torna urgente a adoção de um método que não ignore os fatos isolados, mas que os mantenham em conexão com a totalidade da realidade e da história dos homens. Contrapor os fluxos culturais hegemônicos é essencial a uma 
reavaliação teórico-crítica significativa, tal como Benjamin Abdala Junior (2012) induz em sua opção por blocos comunitários ${ }^{2}$, num movimento que parte

[...] do texto literário às demais séries culturais, valorizando assim o modo (subjetivo) de conhecimento da realidade que provém da literatura, onde se manifestam as dimensões de desejo (potencialidade subjetiva), em nível não apenas individual, mas também das aspirações dos grupos sociais (ABDALA JR., 2012, p. 45).

O conto, por conter elementos tradicionais e modernos, mostra-se uma forma narrativa talhada para evidenciar transformações histórico-sociais em estreita conexão com os impasses da vida nacional, tendo em vista que a literatura faz parte de tal processo. A integração de países emergentes, geralmente ex-colônias, no mundo capitalista moderno, realça aspectos que não só revelam o seu atraso diante da modernização precária, mas também salientam modos arcaicos de produção que mantêm povos em condição periférica. No caso de Brasil e Moçambique, o legado da experiência colonial comum faz destacar dois autores contemplados neste trabalho, Bernardo Élis e Mia Couto, cujos contos selecionados dão a ver tais problemas.

Se a compreensão e a concepção de presente são elaboradas pela maneira com que é formado o passado (SAID, 2011, p. 36), será que é possível relacionar esse pretérito, em suas formas míticas e religiosas, com a racionalização presente em sociedades modernas atravessadas pelo modelo excludente do capitalismo ocidental? Ainda, é possível associar essas concepções com um passado colonial marcado pelo domínio integral, cujos limites ultrapassam a simples oposição dialética entre campo e cidade e se estendem ao contraste litoral e sertão, arcaico e moderno, etc? Como tais dilemas foram captados pela forma narrativa do conto?

Para tanto, pretende-se, primeiramente, uma exposição acerca da teoria da forma conto e suas manifestações no Brasil e em Moçambique. Em seguida, uma reflexão relativa às contradições históricas inerentes à formação

\footnotetext{
${ }^{2}$ A proposta de Benjamin Abdala Junior organiza os sistemas literários das literaturas de língua portuguesa em blocos cuja união resulta um macrossistema de literaturas de língua portuguesa. A língua e história relativamente comuns, a partir da colonização, tornam possível a circulação de obras entre esses microssistemas literários e o seu estudo de forma comparada. Sua intenção, cabe ressaltar, adquire um tom político e prospectivo para esses contemplados.
} 
nacional, patentes na contística dos escritores em questão: Bernardo Élis e Mia Couto.

Num outro passo deste trabalho, objetiva-se analisar os contos "Rosa", de Bernardo Élis, e "A avó, a cidade e o semáforo", de Mia Couto, de maneira a destacar as relações conflituosas entre campo e cidade no âmbito de uma configuração nacional subdesenvolvida . Ainda, os contos "Ontem, como hoje, como amanhã, como depois" e "O poente da bandeira", dos respectivos autores mencionados, apresentam o litoral e o sertão igualmente como cenários de contraste tensionados por uma conformação histórica ambivalente.

Por último, os contrassensos da vida social em área subdesenvolvida são examinados, tendo em conta a experiência do mito e da religiosidade em territórios tropicais, a qual pode ser notada nos contos "A virgem santíssima do quarto de Joana" e "A velha engolida pela pedra", bem como a ambiguidade inerente aos contornos rarefeitos do que seja razão e/ou loucura em "Pai Norato" e "Rosa Caramela", dos mesmos Bernardo Élis e Mia Couto, na devida ordem.

Consideramos que os contos escolhidos apresentam não só as tensões aqui categorizadas, mas também a percepção das transformações históricas e sociais que caracterizam essas ex-colônias, de maneira que se faça uma reavaliação contra-hegemônica do processo vivenciado. Para tanto, é patente o compromisso de cada um desses escritores com a sua nação, por meio da literatura, ao configurar a forma do conto, tal como a chuva sobre a terra seca, pois se trata da tradição, como passado e presente, fecundando a narrativa curta moderna e contemporânea. 


\title{
1. “Já houve até quem visse anjos - muitos anjos - voando nas asas dos pirilampos" ${ }^{\prime 3}$ : sobre o conto
}

\begin{abstract}
História que contam. Tem sumo de verdade? O que parece é que nenhum noivo havia. Ela tirara tudo aquilo de sua ilusão. Inventara-se noiva, Rosita-namorada, Rosa-matrimoniada. Mas se nada não aconteceu, muito foi que Ihe doeu o desfecho. Ela se aleijou na razão. Para sarar as ideias, Ihe internaram [...].

COUTO, Mia. "Rosa caramela". In: Cada homem é uma raça. São Paulo: Companhia das Letras, 2013. p. 15.
\end{abstract}

\footnotetext{
${ }^{3}$ Versos extraídos do poema "O Rêgo", inserido no livro Primeira chuva (1971), de Bernardo Élis.
} 
Ao se explorar a forma do conto e suas particularidades, é necessário pensá-la também aclimatada ao Brasil e a Moçambique, assim, o estudo de seus contornos crítico-teóricos é essencial para se compreender os objetos aqui analisados. Portanto, neste capítulo, em seu primeiro momento, pretendese fazer um levantamento da teoria do conto e seus principais teóricos. Num segundo, realizar uma reflexão acerca do conto no Brasil. E em seguida, dedicar-se uma reflexão sobre o conto em Moçambique.

\title{
1.1. "No oculto do ventre, o feto se explica como o Homem": a propósito da teoria do conto
}

"Um conto sempre conta duas histórias". É o que afirma o contista argentino Ricardo Piglia (2004, p. 89) em suas "Teses sobre o conto". Pensar num relato futuro e não escrito como cisão dos acontecimentos revela-nos uma dupla função do conto, fazendo da história secreta "a chave para a forma do conto e de suas variantes" (PIGLIA, 2004, p. 91). Piglia define que

\begin{abstract}
A arte de narrar é uma arte da duplicação; é a arte de pressentir o inesperado; de saber esperar o que vem, nítido, invisível, como a silhueta de uma borboleta contra a tela vazia.

Surpresas, epifanias, visões. Na experiência renovada dessa revelação que é a forma, a literatura tem, como sempre, muito que nos ensinar sobre a vida (PIGLIA, 2004, p. 114).
\end{abstract}

Descobrir uma narrativa dentro da outra, ou declarar que há narrativas constituintes dessas narrativas, é o que separa Edgar Allan Poe de outros contistas e teóricos modernos.

Em uma tentativa de pensar o modo de compor de Dickens, Godwin e de outros autores, o norte-americano Edgar Allan Poe explora os diferentes arremates de uma narrativa. Poe destaca elementos que considera essenciais à intenção do autor em seu famoso texto "Filosofia da composição" (1848), e acaba por utilizar o seu emblemático poema "The Raven" ("O corvo"), de 1845, como exemplo. A partir do pressuposto de um "efeito único" (POE, 2009, p. 114), formado pela combinação entre os incidentes e o tom, dar-se-á a originalidade almejada pelo autor.

\footnotetext{
${ }^{4}$ Versos extraídos do poema "A pegada", que integra o livro Tradutor de chuvas (2011), de Mia Couto.
} 
A intenção de um efeito poético único nos leva a uma unidade de efeito, ou à totalidade, que tem como contraponto a extensão da obra. Esse resultado também está associado ao belo artístico, à harmonia ou à verdade atingível, trazendo à baila a ideia de tom. Ao tratar das situações, Poe (2009, p. $119)$ as compara com o refrão, numa associação inegável com a poesia, que se fazia juntamente com as ocorrências de "O corvo", cujos efeitos se elevavam em cada estribilho ${ }^{5}$. Assim, tal desenvolvimento não só dá caráter à palavra, mas também delineia melhor os temas tratados.

O resultado, que se faz pelo efeito da variação da aplicação, também ocorre entre o clímax esperado e a gradativa combinação do refrão com as situações. A amplificação do efeito destaca uma geometria de caráter fechado, que não deve ser confundida com a unidade de lugar, apesar de também introduzir ideias (POE, 2009, p.123-127). Isso também diz respeito ao que está contido e ao que não está contido nos limites do real, assim como à complexidade ou à adaptação de sentidos, e da mesma forma, a sugestividade ou a falta de sentidos. O excesso de significados pode fazer de um sentido aludido uma corrente superior, "em vez da subcorrente do tema, que transforma em prosa (e prosa da mais chata espécie) a poesia dos assim chamados transcendentalistas" (POE, 2009, p. 127). Para tanto, destacar-se-á a corrente indefinida de sentido, comumente assimilada ao ideal artístico.

Esse texto de Poe se tornou uma referência para a então denominada teoria do conto. Ao tratar do drama de um jovem que lida com o sofrimento da morte da amada no poema "The Raven", Poe disseca as situações dotadas de ritmo e, por meio da gradação, revela estruturas composicionais semelhantes às tratadas por Aristóteles em sua Poética, no âmbito da tragédia. Ou seja, percebem-se em tal obra os elementos poéticos que inspiram Poe, os quais também revelam a proximidade com a narrativa desde tempos que remontam à Antiguidade, período geralmente associado ao ideal artístico de arte autêntica (LUKÁCS, 2011, p. 49). Assim, para se pensar numa teoria do conto, há de se ponderar também sobre sua história, disparidade capaz de revelar as complexidades estéticas do gênero. Como então ponderar sobre as origens da

\footnotetext{
${ }^{5}$ Tal trecho refere-se à palavra "nevermore" repetida de diferentes maneiras no famoso poema de Poe, The Raven (O corvo).
} 
ação de contar, que existiriam mesmo antes da própria literatura escrita? (GALVÃO, 1983, p. 167)

A literatura oral, desde a Antiguidade, é sinônimo de cultura e educação comuns a todos os cidadãos. Ilíada e Odisséia assim se consolidaram como narrativas que, apesar dos diferentes modos com que se davam as performances da narração, conservavam-se os elementos comuns, de maneira a delinear a narrativa em sua essência. Os versos declamados também eram interpretados por quem contava a história. No caso da tragédia, os versos faziam parte do ritual evocativo que celebrava Dioniso de várias maneiras, com performances que atravessavam a voz e se faziam presentes não só na locução narrativa, mas principalmente nos gestos, na presença de coro, em personagens e nos cenários. Uma progressão destacada nos tragediógrafos Ésquilo, Sófocles e Eurípedes, em escala processual, revela as transformações que teve a tragédia na Antiguidade.

$\mathrm{Na}$ luta do velho contra o novo, a tragédia passa a representar as mudanças que afetam a história dos homens (LUKÁCS, 2011, p. 266). O drama, por sua vez, juntamente com a ascensão das línguas oficiais nacionais, passa a expor cada vez mais a figura do indivíduo diante da nova história a ser erguida. Ao se tornar traço essencial ao novo gênero moderno que se impõe como padrão de análise para a crítica social, o romance faz com que a autoria individual se torne baliza fundamental da obra.

Se o conto surgiu em tempos remotos, desde a Antiguidade, verifica-se que, com a mudança da oralidade para a escrita, das propriedades narrativas de ordens coletiva e individual, não obstante os diferentes modos de dar forma à narração, conserva-se um matiz peculiar que mantém a essência do conto em seus diferentes termos, de acordo com o emprego realizado por distintos povos e nações. Esse gênero, no entanto, adquiriu verdadeiramente o sentido de forma literária a partir dos contos dos irmãos Grimm (JOLLES, 1976, p. 181), durante o século $X I X$. Tais contos tinham como expressão essencial lendas ou fábulas conhecidas, de cunho tradicional e narrativo. Neles encontramos uma expressão essencial que diz respeito ao conto. Ao buscar as forças que sustentavam a beleza interior da realidade popular nacional alemã (JOLLES, 1976, p. 182), durante o seu período romântico, havia um diálogo 
entre a poesia popular e antiga, que se origina do coração da coletividade germânica ${ }^{6}$, ou melhor, um trabalho artístico, cujo princípio moderno se faz na alma individual autoral. Se a poesia antiga é caracterizada como fechada e imutável, em razão de uma menor experiência dos povos, maior é a sua homogeneidade em relação aos contos. Por isso, o poeta deve ter como referencial ascendente o povo, cujas obras maiores são a religião e a poesia antiga (JOLLES, 1976, p. 184-185). Por outro lado, a poesia natural é tida como espontânea, individual, e com maior capacidade de refletir a realidade, de forma mais profunda.

Mesmo se referindo à poesia natural ou antiga, o conto deve instigar as pessoas para que seja contado novamente, tornando uma circunstância de seu atrativo (JOLLES, 1976, p. 186). Isso nos faz perceber que se trata de um gênero que não possui forma fixa ${ }^{7}$. Para isso, há um grande esforço para que este seja renovado, o que verifica pela união de novos elementos aos tradicionais. "Portanto, o poeta moderno dá continuidade, fora do tempo, à obra iniciada pelo poeta antigo" (JOLLES, 1976, p. 186), ou não haveria indícios da existência da poesia épica da antiguidade.

Assim, ao tratarmos da história da poesia, também lidamos com a poesia da natureza em relação à poesia de arte; com a poesia natural e a poesia artificial, com as formas artísticas e as formas simples, título da obra de André Jolles (1976) que discute tais contornos oriundos da Antiguidade e suas transformações nas configurações ditas modernas. No caso do conto, Jolles (1976, p. 188) verifica, por meio das observações de Jacob Grimm, as bases da forma simples e o essencial do gênero. Como formato artístico, desenvolveu-se por intermédio da novela toscana do século XIV, cujos núcleos poderiam ser produzidos de maneira isolada ou de forma coletiva, como foi Decameron, de Bocaccio.

A novela toscana foi espalhada pela Europa e teve sua estrutura de moldura em crescente decadência, marcada pela falta de efeito nos acontecimentos (JOLLES, 1976, p.189), o que contribuiu para a produção de

${ }^{6}$ Considera Jolles que, sendo o conto uma forma artística, há a crença de que "o contador de histórias autêntico é um profeta do futuro" (1976, p. 191), algo aceitável para o nacionalismo romântico da época, em prol da unificação alemã.

${ }^{7}$ A razão desta afirmação se dá pelo fato de que o conto, por meio de sua essência, pode ser contado de diferentes formas. 
novas formas. Por adquirirem cada vez mais destaque em relação à moldura ${ }^{8}$, os acontecimentos ganham relevo cada vez mais especial, o que contribuiu para a popularização das narrativas curtas no Ocidente durante o início do século XVIII, em comparação às narrativas maiores. A moldura italiana, de teor social e paisagístico, deu origem na novela francesa, mas que cada vez mais adquiriu caráter íntimo e doméstico (AUERBACH, 2013, p. 21-40). Segundo Auerbach, a moldura (2013, p. 21) diz respeito à intenção do autor da narrativa. Verifica-se aí um reagrupamento das formas em função do conteúdo, e também com a transformação e a transposição dos gêneros no tempo e no espaço. Entretanto, enquanto conjunto de incidentes cujo resultado só se vê no desfecho da narrativa, a novela se firma como objeto artístico, e o conto é tido como forma simples por dar a "impressão de um acontecimento real, preferindo trabalhar constantemente no plano maravilhoso" (JOLLES, 1976, p. 192).

André Jolles (1976) enumera, a partir do diálogo entre Jacob Grimm e Arnim, as distinções mais analíticas entre a novela e o conto, sendo que a primeira, uma elaboração, é livremente imaginada por seus autores, busca o verdadeiro e o natural, ao garantir maior liberdade de escolha, a partir da realidade empírica por se aplicar a esse universo. No caso do conto, que é tido como forma simples, natural e espontânea, tem como fonte a tradição popular, e mostra-se um amálgama entre o verdadeiro e o natural, e o anseio pelo maravilhoso. Por isso, o âmbito empírico é inerente ao conto, e não o contrário, pois o conto é transportado para o mundo e transforma-se, seguindo somente os princípios que o regem ${ }^{9}$. Assim, o conto, enquanto criação espontânea,

\footnotetext{
${ }^{8}$ A moldura conferia fundo moral e coletivo às novelas, como acontecia nas tragédias.

${ }^{9}$ Comparando à novela, Jolles (1976) explica o processo da forma conto da seguinte maneira:
}

Se examinarmos em seu todo o domínio do Conto, aí encontraremos também uma infinidade de fatos das mais diversas espécies, todos eles ligados, ao que parece, por certa maneira de representar as coisas. Mas desde que se procure aplicar igualmente essa forma ao universo, sente-se que é impossível: não é que os fatos tenham de ser forçosamente maravilhosos no Conto, ao passo que não o são no universo; trata-se, antes, de que os fatos, tal como os encontramos no Conto, só podem ser concebidos no Conto. Numa palavra: pode aplicar-se o universo ao conto e não o conto ao universo.

Se analisarmos a atividade da novela, vemo-la exercer no universo, dar-lhe sua configuração, fixar uma parte desse universo, liga-la de modo tal que a parte só recebe da forma sua representação final e absoluta. Ora, se falarmos da atividade do conto, veremos que 
afirma-se também aberto, móvel, plural e de caráter renovável, considerando a sua força poética. Quanto à novela, por ter elaboração mais técnica, possui caráter fechado, coeso e de acordo com a personalidade do autor. Em relação ao uso da linguagem, a forma simples tem caráter fluido, genérico, sempre renovado, móvel e plural (JOLLES, 1976, p. 196) em razão de suas palavras serem determinadas pela forma. A configuração artística tem as palavras determinadas pelo próprio poeta, daí o seu empenho em ser fechada, sólida, peculiar e única. Aos artistas confere-se o dever moderno de atualizar as formas simples, tornando-as artísticas. As formas simples, entretanto, rejeitam tal acasalamento, dando como resultado uma composição de natureza híbrida, como que denunciando as vozes do povo, destrinchadas. Tal atualização faz perder a mobilidade, a generalidade e a pluralidade próprias da forma simples.

Se o mundo deve se adequar ao conto, há uma disposição mental do conto que é inerente às formas simples. Se a moldura gradualmente desapareceu, a necessidade de readequar a moral ao conto mostra um nivelamento entre a ética do acontecimento e a moral ingênua, as quais atuam no julgamento puramente ético, que também proporciona a satisfação de como as coisas deveriam acontecer (JOLLES, 1976, p. 197-199). Essas foram as condições para que Charles Perrault publicasse seus Contos do passado com moralidades (1697).

A antinomia entre o conto e o acontecimento real sugere uma busca por justiça ou a recusa por um objeto de referência, podendo satisfazer também a moral ingênua. Tal aniquilamento tem um efeito aos moldes do maravilhoso, que é percebido como natural, o que faz de eventos tendenciosos ao extraordinário derivados de milagres ou lendas. Nos discursos

ele trata de compor, primeiro, sua própria fisionomia, antes de se dispor a refletir o universo dela.

Tudo isto pode ser resumido da seguinte maneira: A Novela e o Conto são igualmente Formas; entretanto, as leis formativas da novela são tais que ela pode dar uma fisionomia coerente a todo o incidente narrado, seja real ou inventado, porque tem como característica específica ser impressionante; as leis de formação do conto são tais que, sempre que ele é transportado para o universo, este transforma-se de acordo com um princípio que só rege esta Forma e só é determinante para ela (p. 193-194). [Grifo do autor]

Assim, percebe-se a verossimilhança do conto como que formada a partir de algum dado relacionado ao mundo empírico necessariamente, diferente da novela e do romance, que podem ter, ou não, esse dado. Tal princípio, claro, é dialético. 
convencionais em relação ao conto, ligados ao seu efeito encantatório ou maravilhoso, existe a crença de que quando este adquire traços da história, perde-se parte de sua força por se associar à realidade imoral. $O$ ímpeto ao maravilhoso, então, é dissolvido. Se o gesto verbal se mostra como ação, eis um meio de luta importante contra a realidade imoral. O conto, por isso, mostra-se um registro literário opositivo a um acontecimento real, fazendo de seus próprios objetos irreconhecíveis e adequados às necessidades da moral ingênua (JOLLES, 1976, p. 204).

Se Jolles esforça-se por separar o joio do trigo, numa tentativa de discernir entre as formas simples e a forma moderna do conto, Poe tem como meta o delineamento do feitio moderno do gênero. Júlio Cortázar descreve acerca da relação de Poe com o seu tempo da seguinte maneira:

"A época - diz Hervey Allen -, a peculiar metade do século XIX, na
qual Poe viveu, converteu-se num país perdido para os que vieram
logo depois, um país mais remoto e singular que o Sião. Quando se
contemplam seus vestidos esquisitos, sua estranha arquitetura
rococó, suas crenças, preconceitos, esperanças e ambições, suas
convenções carentes hoje de sentido, mas sobretudo se se busca
uma aproximação através da sua literatura popular, parece como que
um estranho oceano neblinoso, onde, através de ruas apenas
entrevistas, em povoados oniricamente grotescos, se movessem -
por motivos esquecidos - os fantasmas dos trajes. Fora desta terra
de vaga agitação e de apagados lampejos, como um campanário
sobre a névoa que cobre a cidade e sob a qual se ouve passar o
tráfego invisível, umas poucas coisas aparecem delineadas e
definidas claramente. Uma delas é a prosa de ficção e a poesia de
Edgar Allan Poe." (CORTÁZAR, 2013, p.106).

Numa época conturbada, de autoafirmação individual, de um tempo em que a nação estadunidense se industrializava cada vez mais e via o campo como um passado distante (CORTÁZAR, 2013, p. 105-106), Poe surge como um literato de plena maturidade intelectual, mas à parte do mundo moderno, inclusive de seus temas correntes, conforme demonstra o seguinte trecho:

O monstruoso está de imediato aí, presente e inequívoco. A noção de anormalidade se destaca com violência da totalidade de elementos que integram sua obra, seja poesia, sejam contos. [...] Mas nada, diurno ou noturno, feliz ou infeliz, é normal no sentido corrente que aplicamos mesmo às anormalidades vulgares que nos rodeiam e nos dominam e que já quase não consideramos como tais. $O$ anormal, em Poe, pertence sempre à grande espécie (CORTÁZAR, 2013, p. 107108).

E, admitindo-o como tal, compara:

Sua poética é como que uma tentativa de negar o tronco da árvore e afirmar, ao mesmo tempo, seus ramos e sua folhagem; de negar a 
irrupção veemente da substância poética, mas aceitar suas modalidades secundárias (CORTÁZAR, 2013, p. 114).

Sendo sua poética um modo de se afirmar como indivíduo,

[...] é lícito suspeitar, à luz de uma análise global de impulsos e propósitos, que a relojoaria de $O$ corvo nasce mais da paixão que da razão, e que, como em todo poeta, a inteligência é alí auxiliar do outro, disso que "se agita nas profundezas", como o sentiu Rimbaud (CORTÁZAR, 2013, p. 119).

Ou seja, Poe admite o reflexo lírico como reflexo da realidade objetiva, sendo um comportamento que cria e problematiza simultaneamente a realidade (LUKÁCS, 2011, p. 245-247), características essenciais para compreender o conto cuja composição Poe tenta caracterizar. Afinal, conforme trata Cortázar, o ideal artístico de Poe, associado à sua originalidade, deve-se à lírica. Por isso, o conto deve ser entendido também como processo poético, que possui caráter híbrido, conforme apontara Jolles, ou também de acordo com a noção de Poe, denominada de "efeito único", o que torna ainda mais curioso o processo de construção de uma forma simples:

[...] para revelar artificialmente algo que estava oculto. Reproduz a busca sempre renovada de uma experiência única que nos permite ver, sob a superfície opaca da vida, uma verdade secreta. "A visão instantânea que nos faz descobrir o desconhecido, não numa remota terra incógnita, mas no próprio coração do imediato", dizia Rimbaud. Essa iluminação profana converteu-se na forma do conto (PIGLIA, 2004, p. 94).

Essa visão também fortalece o ponto de vista de Cortázar $^{10}$ (2013) acerca da forte presença do gênero conto, de seu valor periférico e marginalizado para a crítica moderna, ao menos nos primórdios. Nas literaturas jovens ${ }^{11}$, tendo em vista as literaturas latino-americanas, cuja criação espontânea tem mais vantagens do que a sua crítica supõe (p. 149-150), pensa-se no conto como aquele que

[...] se move nesse plano do homem onde a vida e a expressão escrita dessa vida travam uma batalha fraternal, se me for permitido 0 termo; e o resultado dessa batalha é o próprio conto, uma síntese viva ao mesmo tempo que uma visa sintetizada, algo assim como um tremor de água dentro de um cristal, uma fugacidade numa permanência. Só com imagens se pode transmitir essa alquimia secreta que explica a profunda ressonância que um grande conto tem

${ }^{10}$ Ao escrever o texto "Alguns aspectos do conto" (1970), o argentino Júlio Cortázar vivia em Paris, na França, mas era politicamente comprometido com a América Latina, mesmo durante seus regimes ditatoriais.

${ }_{11}$ Tal afirmação diz respeito às literaturas nacionais, cujos processos libertários, ou de independência política, se deram tardiamente. 
em nós, e que explica também por que há tão poucos contos verdadeiramente grandes (CORTÁZAR, 2013, p. 150-151).

Ao se ligar à vida, e também à História, o conto é comparado ao romance e ao cinema, cuja captação da realidade

[...] mais ampla e multiforme é alcançada mediante 0 desenvolvimento de elementos parciais, acumulativos, que não excluem, por certo, uma síntese que dê o "clímax" da obra, numa fotografia ou num conto de grande qualidade se precede inversamente, isto é, o fotógrafo ou o contista sentem necessidade de escolher e limitar uma imagem ou um acontecimento que sejam significativos, que não só valham por si mesmos, mas também sejam capazes de atuar no espectador ou no leitor como uma espécie de abertura, de elemento que projete a inteligência e a sensibilidade em direção a algo que vai muito além de um argumento visual ou literário contido na foto ou no conto (CORTÁZAR, 2013, p. 151-152).

Seu caráter incisivo faz com que, apesar da enorme profundidade, 0 conto se atenha a uma pouca extensão. Friedman (2004) destaca que a razão do conto ser curto se deve ao fato de sua ação ser "intrinsicamente curta, ou porque sua ação, sendo longa, é reduzida em tamanho por meio de recursos de seleção, escala ou ponto de vista" (p. 230).

Sem tentar ser prescritivo, Friedman pensa nos princípios do conto com foco na razão e nos meios de manter a sua brevidade. Aspectos a serem destacados para qualquer análise, em vista do principal elemento de valoração do gênero, que é a brevidade, em detrimento da ação, cuja interferência dá-se no caráter da narrativa, que pode ser estática ou dinâmica ${ }^{12}$.

Quanto aos seus elementos significativos, a abertura provocada pela "alta pressão espiritual e formal", nos termos de Cortázar (2013, p. 152), entre tempo e espaço, faz surgir a significação dos temas, cuja tensão e intensidade são essenciais para uma boa avaliação crítica. Liquidar os limites com essa pressão faz com que a história do conto se expanda e vá além dos seus limítrofes.

O tema mostra-se um modo de estranhamento ao mundo, um empenho próprio do contista ao escrever o conto. Por se tratar também de um território embrionário da memória e da experiência, diz Cortázar, ao mencionar

12 Friedman (2004, p. 224) diz ser a narrativa estática aquela que apresenta uma única situação com pouca extensão. Acerca da narrativa dinâmica, seria aquela que apresenta a sucessão de duas ou mais situações e muitas etapas casuais, o que acarreta diversas consequências. 
o exemplo argentino, o conto mantém sua relação com a oralidade, cujas narrativas

[...] em si são saborosas, traduzem e resumem a experiência, o sentido do humor e o fatalismo do homem do campo; alguns se elevam mesmo à dimensão trágica ou poética. Quando os ouvimos da boca de um velho gaúcho, entre um mate e outro, sentimos como que uma anulação do tempo, e pensamos que também os aedos gregos contavam assim as façanhas de Aquiles para maravilha de pastores e viajantes. Mas nesse momento, quando deveria surgir um Homero que fizesse uma llíada ou uma Odisséia dessa soma de tradições orais, em meu país surge um senhor para quem a cultura das cidades é um signo de decadência, para quem os contistas que todos nós amamos são estetas que escreveram para o mero deleite de classes sociais liquidadas, e esse senhor entende, em troca, que para escrever um conto a única coisa que faz falta é registrar por escrito uma narrativa tradicional, conservando na medida do possível o tom falado, os torneios do falar rural, as incorreções gramaticais, isso que chamam a cor local (CORTÁZAR, 2013, p. 158-159).

Do resultado estético esperado, entretanto, devem ser considerados os bons frutos encontrados, a serem aproveitados tanto por leitores do campo quanto da cidade. As escolhas dos traços constituintes dos contos e dos temas são capazes de potencializar o efeito do conto. Para tanto, Cortázar explana tal objetivo, ao destacar escritores como

Um Roberto J. Payró, um Ricardo Güiraldes, um Horacio Quiroga e um Benito Lynch que, partindo também de temas muitas vezes tradicionais, ouvidos da boca de velhos gaúchos como um Dom Segundo Sombra, souberam potenciar esse material e torná-lo obra de arte. Mas Quiroga, Güiraldes e Lynch conheciam a fundo o ofício de escritor, isto é, só aceitavam temas significativos, enriquecedores, assim como Homero teve de pôr de lado uma porção de episódios bélicos e mágicos para não deixar senão aqueles que chegaram até nós graças à enorme força mítica, à ressonância de arquétipos mentais, de hormônios psíquicos como Ortega y Gasset chamava os mitos. Quiroga, Güiraldes e Lynch eram escritores de dimensão universal, sem preconceitos localistas ou étnicos ou populistas; por isso, além de escolherem cuidadosamente os temas de suas narrativas, submetiam-nos a uma forma literária, a única capaz de transmitir ao leitor todos os valores, todo o fermento, toda a projeção em profundidade e em altura desses temas. Escreviam tensamente, mostravam intensamente. Não há outro modo para que um conto seja eficaz, faça alvo no leitor e crave em sua memória (CORTÁZAR, 2013, p. 159).

A essência e o conhecimento das narrativas associadas, então, são fundamentais à configuração do conto, elementos esses que hoje caracterizam o conto moderno de eixo americano-europeu, cujo marco histórico é a segunda revolução industrial. Na verdade, o conto moderno

[...] faz parte da tomada do poder literário pela prosa de ficção impressa, e mais especificamente pela prosa publicada em jornal 
diário - o que se efetiva no século passado, em meio ao processo de popularização do épico para ser lido.

O conto está indissoluvelmente ligado aos primeiros balbucios da indústria cultural, ou seja, à extensão do capitalismo ao campo da cultura, com o surgimento da imprensa periódica mantida por anúncios (GALVÃO, 1983, p. 168).

Assim, se o conto também se faz "resquício do velhíssimo ato de contar, ele também é - então - o que havia de mais moderno como mercadoria" (GALVÃO, 1983, p. 168-169). Sendo cada vez mais modelado em conformação com as demandas jornalísticas, em razão da reprodução técnica e da democratização da informação (GALVÃO, 1983, p. 169), o conto também tem sua liberdade criativa gradualmente limitada, uma vez que

O conto, que por sua natureza é ficção, jogo livre da imaginação, passa a competir com a forma da notícia de jornal; a contradição se instaura entre conto e informação jornalística.

A boa forma da informação imita a forma do conto, e a boa forma do conto imita a informação, finge que é pura informação: o conto quer ser notícia de jornal, a notícia de jornal quer ser conto (GALVÂO, 1983, p. 169).

Concomitantemente, há também a perda progressiva da tradição, associada à habilidade de narrar que, em meio às tradicionais bases culturais diluídas pelo capitalismo internacional, faz do trabalho manual, associado ao conto, já agora desmerecido de atenção diante de um contexto em que

A informação só tem valor no momento em que é nova. Ela só vive nesse momento, precisa entregar-se inteiramente a ele e sem perda de tempo tem que se explicar nele. Muito diferente da narrativa. Ela não se esgota jamais. Ela conserva suas forças e depois de muito tempo ainda é capaz de desdobramentos (BENJAMIN, 2012, p. 220).

Nessa associação à imprensa periódica, destaca-se o conto de atmosfera, cujo "modelo tinha força disruptiva e criadora naquela fase da revolução industrial, mas de há muito tempo, já a perdeu" (GALVÃO, 1963, p. 171). Porém,

O conto foi suplantado no jornal diário pela crônica, que tem caráter menos desenvolvido ficcionalmente mas que está hoje em todos eles, assinada por autores que fizeram antes seu renome nos gêneros considerados nobres (GALVÃO, 1983, p. 172).

Apesar da distância entre o narrador e a matéria narrada, em razão da evolução dos meios de produção, o conto escrito é potencial espaço narrativo que registra a sua própria degradação da forma, a tradição de contar sobre quem o produz e sobre quem o lê, e também sobre ele mesmo enquanto 
gênero. Sua renovação, no entanto, é importante instrumento de rearranjo da memória histórica da cultura, o que implica "o esquecimento da violência e dos aspectos traumáticos"13 (LEITE, 2014, p. 106), na demanda em prol da construção da nação moderna, males que, em nações colonizadas, não são simplesmente esquecidos ou negligenciados por grandes escritores da narrativa curta, tanto no Brasil quanto em Moçambique, mas ressignificados.

\section{2. "Hoje, como conheço história do Brasil, mudei a data de meus anos, que é o dia mais triste do mundo"14: sobre o conto no Brasil}

Como não poderia ser diferente, o conto moderno no Brasil teve a sua origem associada aos jornais, veículos de divulgação do gênero, cuja instauração ocorrera durante a estadia da família real no Brasil. Apesar disso, muitas de suas manifestações orais, que antecedem o conto impresso, mostram que a forma conto, como é elementar do gênero, é vinculada à tradição popular, principalmente ao cordel. Apesar de a imprensa apresentar uma nova maneira de tratar o gênero em território brasileiro, este passou a ocupar lugar marginal na literatura, em comparação ao que estava em voga na literatura recentemente nacionalizada, o romance: o principal instrumento de descoberta e interpretação do país, que não só foi responsável pela amplificação do público leitor durante o período romântico, mas também se fez gênero flexível capaz de reinventar origens e descrever a realidade social (CANDIDO, 2009, p. 429-430). Mesmo em detrimento do romance, Fábio Lucas (1989) diz que

a dimensão do conto e a particularização de seu conflito fizeram-se distinguir-se da outra grande forma narrativa, o romance: enquanto este, dadas a complexidade da ação e da metamorfose da personagem, torna-se o estuário de tal multiplicidade de relações que o torna homólogo à própria sociedade, que se vê transcrita repetidas vezes no relato romanesco, aquele tende a captar a individualidade (LUCAS, 1989, p. 108).

Continua Lucas:

\footnotetext{
${ }^{13}$ No artigo citado, que trata especificamente dos romances moçambicanos Choriro (2009), de Ungulani Ba Ka Khosa, e O outro pé da sereia (2006), de Mia Couto, o trecho selecionado aponta aspectos problemáticos que envolvem a formação das nações modernas impressas nessas obras ficcionais. O conto, por ser também um rearranjo da memória, também se encaixa nesse quesito.

${ }^{14}$ Estrofe extraída do poema "O homem que fazia anos no dia sete de setembro", inserido na coletânea Primeira chuva (1971), de Bernardo Élis.
} 
Grosso modo, podemos dizer que o romance é filho remoto da epopeia e provém modernamente da História, do relato de viagens e conquistas, enquanto o conto retira sua origem de várias formas de narrativa doméstica, a fábula, a anedota, o caso, o provérbio, os enredos curtos de tom libertino, piedoso ou moralizante (LUCAS, 1989, p. 108).

Assim, o referido crítico associa a modernidade do conto à imprensa, principal veículo de divulgação do gênero, e também destaca a particularização do conflito por meio de formas narrativas domésticas. Desse modo, com a constituição da sociedade prosaica da vida burguesa, no âmbito brasileiro, os discursos adquiriram uma ordem cada vez mais pragmática (LUCAS, 1989, p. 109) e um caráter cada vez mais dramático.

O poeta Álvares de Azevedo foi o realizador do primeiro marco da contística brasileira, A noite na taverna (1855). A narração dos relatos dos seis jovens bêbados, reunidos num ambiente peculiar, inaugura uma tradição de unidade autônoma de personagens, tema ou atmosfera própria da contística brasileira (LUCAS, 1989, p. 114).

O espírito romântico de $A$ noite na taverna, no entanto, cede lugar para o segundo marco do conto no Brasil. Se o realismo, em razão de sua modernidade, cristalizou os contos de Guy de Maupassant como modelo do gênero, sendo comparados ao soneto em razão de sua unidade, Machado de Assis fez o conto atingir sua máxima perfeição no nosso sistema literário. Os cerca de duzentos contos produzidos não são tão levados a sério pela crítica, de acordo com o inglês John Gledson (1998, p. 15), entretanto. Anedotas e detalhes triviais acabam por jogar luz a assuntos de suma importância, que muito tem a ver com a realidade nacional, alcançando também um caráter ensaístico. Em uma fase mais avançada da contística do autor fluminense, Lucas (1989, p. 115) destaca que "[...] o uso parodístico do gênero prenunciava o lento desaparecimento da personagem-caráter e da urdidura anedótica, em proveito de uma revolução da linguagem e da problematização da escrita". Em muitos aspectos, o conto machadiano é reconhecido como contributo fundamental para a modernização do conto brasileiro, dada a sua linguagem enganosamente simples, tendo em vista a oralidade dos centros urbanos, principalmente do Rio de Janeiro onde vivia o escritor, e também o tom de confidencialidade com que narrava os difíceis episódios da vida cotidiana. Seu 
texto é composto de "[...] idas e vindas que intensificam ou abrandam os estados psíquicos despertados" (LUCAS, 1989, p. 115), cabendo ao leitor completar o sentido sugerido pelo autor, algo que também pode ser considerado um arcaísmo do gênero em causa. Este seria o grande marco de sua modernidade, sendo que o conto machadiano ainda influenciou outros grandes contistas no início do século XX. Segundo Antonio Candido:

\begin{abstract}
Curiosamente, este arcaísmo parece bruscamente moderno, depois das tendências de vanguarda do nosso século, que também procuram sugerir o todo pelo fragmento, a estrutura pela elipse, a emoção pela ironia e a grandeza pela banalidade. Muitos dos seus contos e alguns dos seus romances parecem abertos, sem conclusão necessária, ou permitindo uma dupla leitura, como ocorre entre os nossos contemporâneos. E o mais picante é o estilo guindado e algo precioso com que trabalha e que se de um lado pode parecer academismo, de outro sem dúvida parece uma forma sutil de negaceio, como se o narrador estivesse rindo um pouco do leitor. Estilo que mantém uma espécie de imparcialidade, que é a marca pessoal de Machado, fazendo parecer duplamente intensos os casos estranhos que apresenta com moderação despreocupada. Não é nos apaixonados naturalistas do seu tempo, teóricos da objetividade, que encontramos o distanciamento estético que reforça a vibração da realidade, mas sim na sua técnica de espectador (CANDIDO, 2011, p. 22-23).
\end{abstract}

Ao delinear o particular tom machadiano, de caráter esteticamente neutro, Candido ainda descreve a especificidade da técnica de Machado da seguinte maneira:

A sua técnica consiste essencialmente em sugerir as coisas mais
tremendas da maneira mais cândida (como os ironistas do século
XVIII); ou em estabelecer um contraste entre a normalidade social
dos fatos e a sua anormalidade essencial; ou em sugerir, sob
aparência do contrário, que o ato excepcional é normal, e anormal
seria o ato corriqueiro. Aí está o motivo da sua modernidade, apesar
do seu arcaísmo de superfície" (CANDIDO, 2011, p. 23).

Ou seja, o engendramento das situações ficcionais narradas dá a ver a constante oscilação entre essência e aparência, que é capaz de surpreender o leitor, colocando-o diante da teia narrativa, assim denominada por Candido. Sem se render ao descritivismo romântico, ao representar a natureza de sua terra, optou por dar "universalidade ao seu país pela exploração, em nosso contexto, dos temas essenciais" (CANDIDO, 2011, p. 22). E ainda, seu famoso texto "Instinto de nacionalidade" (1873) deslocou as ações do regionalismo pitoresco para os conflitos existenciais do homem brasileiro. Passo essencial não só para o desenvolvimento da literatura nacional, mas também para perspectivar o gênero conto num sistema literário periférico. 
Inicialmente, movido pelos anseios românticos, o conto regionalista tem o seu ideal fundador exposto do seguinte modo por Luiz Gonzaga Marchezan (2009):

O ideário fundador do conto regionalista nacional constitui-se na disposição dos enredos de casos, e estes, várias vezes, com o modo de expressão da fábula. A fábula e o caso, no interior de uma narrativa regionalista, têm como função tipificá-lo. A fábula, pela ação da fauna e da flora e por meio de metamorfoses e de personificações, mais adquirem qualidades inerentes a uma pessoa.

Os contos regionalistas realizam-se, assim, como casos e fábulas. Fábulas quando, com o seu campo imaginário, trabalham ora verdades lendárias, de inspiração ainda romântica, ora julgamentos de dados comportamentos, momento de tendência realista. O conto regionalista, enfim, no que tipifica, dramatiza, conforme vimos por meio do pensamento do sociólogo Octavio lanni, ora situações de mistérios, ora de violência (MARCHEZAN, 2009, p. XLI).

O mencionado crítico assim explica a origem dos casos e fábulas:

Casos e fábulas constituem-se de vozes advindas de diversos lugares discursivos: são vozes reunidas, coletadas - ecos de vozes distantes, memórias coletivas. Fábulas e casos querem falar de um espaço tanto atemporal como temporal, entre o humano e o divino, o consciente e 0 inconsciente, o perceptível e o imperceptível, inatingível, e ganham força através de uma linguagem com expressão regionalizada (MARCHEZAN, 2009, p. XLI).

Essa fonte mostrou-se, depois das contribuições de nomes como Simões Lopes Neto e Coelho Neto, um singular manancial para o marco prémoderno do conto, cuja figura expoente é Monteiro Lobato. A lógica da cadeia de ações e a causalidade definida no fluxo temporal são marcas do referido escritor paulista, que faz de suas convicções a respeito do país, materializadas em caricaturas, gracejos e cenas melodramáticas de cunho patético, modelos para seus contos de caráter publicitário. Assim como aconteceu em Urupês (1918) (LUCAS, 1989, p. 116), cuja famosa personagem de Jeca Tatu, na concepção lobatiana, torna-se não só sinônimo do atraso perante a modernização desigual e precária, mas também a justificativa de o conto ser mais curto, movido pela preguiça nacional metaforizada pelo personagem analfabeto. Esse também foi um ponto considerado no projeto de criação de casas editoriais pelo mencionado escritor.

O romanticismo pitoresco, apesar de ainda apreciado pelo público, pouco seduziu Mário de Andrade, cuja contística muito contribuiu para a liberdade de composição, tendência natural do movimento modernista de 1922. Assim, 
A visão moderna do conto encarregou-se de despojar a narrativa curta de seu tratamento pomposo e prolixo, tratou de cortar uma floresta de verbosidade, desbastou a escrita de clichês mortos. O trabalho inicial foi o da paródia, ou seja, abandonou-se a função analógica que leva à estilização, e entregou-se à função inversa (que impõe a paródia), revertendo-se o sentido da fórmula consagrada e inserindo-a num contexto oposto. A prosa límpida de um Dalton Trevisan, de um Rubem Fonseca, de um Luís Vilela, é fruto de um longo percurso (LUCAS, 1989, p. 117).

As anedotas curiosas, as preocupações familiares, o tom psicológico descrevem o estilo de Mário de Andrade, um modo de composição que, além de ser opção estética do autor, também é reflexo da complexificação de temas no cenário brasileiro, que em escala gradual vai realizar a passagem do romance ao conto (LUCAS, 1989, p. 118).

O regionalismo brasileiro, em sua fase de maior ênfase sócio-política, ocorre durante a década de 1930, um período no qual fora importante a conscientização da posição da nação brasileira diante do mundo, de sua literatura e de sua matéria histórica. Autores como Graciliano Ramos, Rachel de Queiroz e Jorge Amado destacam-se neste período. Ao deslocar o espaço narrativo dos grandes centros para as áreas até então ignoradas pelo campo literário hegemônico, o nordeste brasileiro ganha maior importância para que se concretize a unificação proposta pelo projeto modernista em sua primeira fase, agora mais amadurecido ideologicamente.

Influenciado por tal estética, a contística de Bernardo Élis foi produzida após a década de 1930, numa quadra na qual o escritor goiano fora contemporâneo de Guimarães Rosa, autor de Sagarana (1946). Tal circunstância demonstra uma maior preocupação em problematizar um espaço inóspito e central do território brasileiro, de modo a testemunhar a modernidade tardia, que custava a chegar ao sertão goiano nas décadas de 1940, 1950 e 1960. E ainda, vivia-se uma nova ordem cultural instaurada, com a qual as mudanças da cidade não são acompanhadas pela vida rural atrasada.

Tais manifestações literárias são transformadas pela pesquisa de novas linguagens (JAMESON, 2006, p. 43-44), movimento que subverte os sentidos históricos ultrapassados, em favor do desaparecimento de um sentido 
de passado a ser abandonado ${ }^{15}$. Essa tendência acaba por culminar numa realidade fragmentada e em novas tendências do conto, a partir dos veículos midiáticos de hoje, de acordo com Walnice Nogueira Galvão (1983, p. 172). Diz ela que, se por um lado o conto perdeu sua força criativa, ao ser suplantado pelas crônicas dos jornais, o principal veículo divulgador do gênero, por outro, o conto esgotou as possibilidades de produzir entrechos realistas, por se restringir à reprodução das mesmas soluções, daí a necessidade de criação de novos paradigmas estético-formais (p. 171-172).

\section{3. “Eu tive um país pequeno, tão pequeno, que não cabia no mundo"16: sobre o conto em Moçambique}

As sociedades africanas têm como matriz histórica e diegética a oralidade, modalidade ligada a visões de mundo homogêneas e mitificadas. $O$ conto tinha, em sua expressão arcaica (oral), a função de transmitir a herança cultural, assumindo uma condição didática explícita. Afinal, "o conto oral se enraíza nas origens mais profundas das culturas africanas de que representa verdadeiramente a permanência e o movimento" (AFONSO, 2004, p. 67). Mesmo com sua insistência "em escapar à armadilha impiedosa do progresso" (AFONSO, 2004, p. 68), o conto moderno tende a realizar uma ruptura e reequacionar o passado, mantendo com o tempo atual as exigências técnicas da escrita, cuja marcas são os intertextos e a herança da oralidade manifesta em traços coletivos e particulares reconhecíveis em seus artífices (AFONSO, 2004, p. 69).

O conto aparece como gênero preferencial para os escritores africanos por razões políticas. Se a imprensa é tida como um espaço de produção literária, também se faz veículo ligado às reivindicações político-sociais (AFONSO, 2004, p. 71). Esse caráter duplo confere ao gênero maior diversidade de temas, máximo entrelaçamento de linguagens, mais

\footnotetext{
${ }^{15}$ Devido ao movimento cultural do pós-modernismo, ocorre não só o fim da história como percepção da história ainda em curso, mas também existe a crença de que as manifestações que dizem respeito às tradições culturais são uma expressão entre outras. Em suma, desconsidera-se a progressão de tais formas de expressão como pertencentes a uma história da arte, da literatura e da língua como um todo para dar-lhes a denominação de estilo que pode ser seguido na lógica do consumo.

${ }^{16}$ Estrofe extraída do "Poema didático", inserido no livro Tradutor de chuvas (2011), de Mia Couto.
} 
acessibilidade das classes sociais desfavorecidas, caracterizando-o como suporte literário de maior criatividade. Na verdade,

Mais do que um simples criador, o escritor africano aparece como um actor que toma partido num mundo opressor, proclamando a dimensão intertextual da sua palavra, a libertação do jugo colonial e da alienação cultural (AFONSO, 2004, p. 78).

Se a África de língua portuguesa fora recém-descoberta pelo restante do mundo, isso revela, na verdade, certo grau de superficialidade com que é tratada. Sua literatura oral pré-colonial foi a que primeiro surgiu no continente africano, o que manifesta sua profunda conexão com a verdadeira história do continente africano (AFONSO, 2004, p. 67). Afonso utiliza-se dos vários significados que a palavra conto pode adquirir como exemplo disso:

A palavra portuguesa "conto" que refere simultaneamente o conto oral, tradicional, e o conto de autor, podendo este também ser designado por "conto moderno", "conto literário", "estória", "história" e "short story" (AFONSO, 2004, p. 79).

Os países de língua oficial portuguesa possuem como características comuns a publicação dos primeiros textos e livros, geralmente em Lisboa: o papel decisivo da imprensa local; o advento dos movimentos de libertação; a solidariedade do espaço e do tempo histórico, mesmo que afirmando-se independentes (AFONSO, 2004, p. 80) foram fundamentais para a mudança de rumo. Assim, por seus variados meios literários, surgiram literaturas de diferentes dimensões, classificadas por tais características como consulares e insulares $^{17}$. Angola e Moçambique possuem como expoentes a polifonia multicultural e linguística, o que leva à decisão sobre qual língua escolher para a escrita. A maior parte dos escritores africanos escreve numa das línguas europeias, apesar de que tal alternativa possa não representar a totalidade da situação linguística do país, como no caso dos dois países citados, cujas línguas, à exceção da língua do colonizador, são de raiz bantu. Tal coabitação linguística se reflete na escrita híbrida, reflexo dos movimentos de libertação

${ }^{17}$ Essas categorizações foram essenciais para os estudos das literaturas africanas de língua portuguesa, uma vez que consideram as matrizes linguísticas e culturais comuns para melhor sistematizar essas literaturas. Elas consideram a geografia e o movimento desses povos pelo continente. Com isso, a classificação de literaturas consulares referem-se àquelas cujos países são majoritariamente agrupados ao continente africano. São exemplos as literaturas angolana, moçambicana e guineense. Quanto às literaturas insulares, referem-se àquelas cujos países majoritariamente não se encontram integrados ao continente africano. São exemplos as literaturas cabo-verdiana e são-tomense. 
dos países africanos de língua portuguesa durante o regime salazarista, ocasião em que, principalmente nos jornais, a composição literária assumia contornos de uma escrita própria, condizente com as identidades nacionais em afirmação (AFONSO, 2004, p. 108-109). No caso de Moçambique, o conto tornou-se instrumento libertário por excelência. Como as outras literaturas africanas de língua portuguesa, há o enfrentamento de

\begin{abstract}
Problemas específicos de regiões sujeitas a regimes coloniais: identidade dos escritores, definição dos gêneros literários cultivados, emprego de linguagens contrárias aos cânones linguísticos europeus. Nas sociedades multiculturais, definir um autor africano a partir de factores somáticos, cor da pele ou cabelos encarapinhados, do seu lugar de origem, ou do seu empenhamento na denúncia da opressão do sistema colonial e, mais tarde, no combate anticolonial, suscita questões por vezes dramáticas (AFONSO, 2004, p. 121).
\end{abstract}

No que tange especialmente ao território moçambicano, destacar-se-á que "a literatura moçambicana nasceu num contexto cultural mais segregacionista do que os das outras colônias" (AFONSO, 2004, p. 121). Suas primeiras manifestações, ao princípio do século XIX, estavam na contracorrente das políticas assimilacionistas do estado colonial. Apesar das diferentes agremiações que dividiam negros e brancos, os intelectuais fizeram despertar uma consciência nacional capaz de lutar contra as injustiças e abusos que a condição de colônia submetia a todos, tais como a imposição da política colonial e as demandas do sistema educativo (AFONSO, 2004, p. 123). Ao tomar consciência da ação opressiva do aparelho colonial, os assimilados fizeram da imprensa um espaço privilegiado para tal, o que possibilitou o surgimento de uma identidade africana e uma escrita literária moçambicana (AFONSO, 2004, p. 125). Na verdade,

Para lá do papel que teve na tomada de consciência de uma
especificidade africana, a imprensa foi quase exclusivamente o único
meio ao alcance de gerações de escritores cujos textos constituíram
o suporte de uma acção que assumiu o aspecto de um movimento
político e cultural. Forte e reivindicativa, a palavra literária desperta
para a realidade moçambicana, anuncia a luta de libertação nacional
e partilha os sonhos e os compromissos dos escritores das outras
colónias do Império português (AFONSO, 2004, p. 126).

A revolta contra as políticas do regime salazarista durante a década de 1950 colocou em destaque uma identidade moçambicana, cuja maior expressão ocorreu por meio da poesia. A poetisa Noémia de Sousa tornou explícito o compromisso com a terra e o povo de Moçambique. Por sua vez, 
José Craveirinha, em pleno movimento da negritude, destacou os abusos coloniais na figura do griot $^{18}$ e na utilização das tradicionais formas narrativas orais, cujos atributos são considerados mágicos, o que revela a "imagem de passado tradicional, histórico e literário, onde enraíza sua identidade africana, com a visão de um futuro ainda a construir e do qual o poeta se faz profeta" (AFONSO, 2004, p. 129).

O compromisso ideológico durante os anos 1960 é marcado por uma literatura de combate. O comprometimento político imbrica-se ao discurso poético, recaindo sobre a demanda identitária da cor da pele, uma questão complexa e que diz respeito à formação social e étnica moçambicana. Duas grandes correntes surgiram numa época anterior à independência. A primeira, libertária, gira em torno do conceito de moçambicanidade, e tem como membros Rui Noronha, Noémia de Sousa, José Craveirinha e outros. A segunda, heterogênea e supra-racial, tem como membros Vergílio de Lemos, Orlando Mendes, Rui Knopfli e outros.

A cisão representativa encontra-se nas figuras emblemáticas de José Craveirinha, cuja poética revelava-se como uma espécie de guardião da memória da tribo, e Rui Knopfli, cuja maior representatividade dá-se pela modernidade conflituosa, mas sempre em prol da dignificação do homem. Considerando que esses poetas também iniciaram a prosa de ficção moçambicana, pode-se pensar no conto em Moçambique nessas mesmas linhas de raciocínio aludidas.

"A fiç̧ão narrativa de raiz marcadamente moçambicana ocorre na segunda metade do século XX", de acordo com Nelson Saúte (2001, p. 13), em sua antologia de contos moçambicanos $A s$ mãos dos pretos, cujo título remete a um conto de Luís Bernardo Honwana, também autor da incontornável obra fundadora da ficção moçambicana: Nós matamos o cão tinhoso (1964). Em seu período pré-independência, a prosa de fiç̧ão moçambicana exprime-se por meio de casos isolados (manifestações literárias), como não só o caso do livro de contos de Honwana, mas também a obra Contos e lendas (1974), de Carneiro Gonçalves.

\footnotetext{
${ }^{18} \mathrm{Na}$ tradição africana, a figura do griot está ligado a ofícios como de poeta, contador histórias, músico e cantor. São-lhe atribuídos poderes sobrenaturais.
} 
evento da independência do país tornou-se marco não só político, mas também um importante acontecimento cultural que propiciou uma tradição literária digna da constituição de um sistema literário próprio. A dinamicidade da imprensa e o contato com a vida social e política dos novos tempos fez com que a preocupação com o advento da modernidade e a tradição da oralidade adquirissem um tom diferente, sem tradição ainda no romance ${ }^{19}$ (AFONSO, 2004, p. 158). Por possuir barreiras artificiais entre os gêneros, na concepção do autor Mia Couto, o conto tornou-se o gênero libertário e mais próximo da poesia, o que possibilitou, durante a década de 1980, o surgimento de autores como Albino Magaia, Aníbal Aleluia, Calane da Silva, Hélder Muteia, Isaac Zita, Ungulani Ba Ka Khosa, Suleiman Cassamo e o próprio Mia Couto.

A FRELIMO - Frente de Libertação de Moçambique - propõe a criação da Associação de Escritores Moçambicanos (AEMO), órgão capaz de refletir as várias concepções acerca do estado-nação em construção, e a revista Charrua mostrou-se um exemplo de ação cultural como veículo caracterizado pela multiplicidade de posturas estilísticas e linguagens (SAÚTE, 2001, p. 14). No contexto de mundo globalizado (NOA, 2015, p. 30), a literatura moçambicana, como literatura africana, inverte a raiz de influência centro-periferia, perceptível nos discursos ocidentais, na estratégia de paratextos ${ }^{20}$, um diálogo capaz de dar feição não só de tradição, mas de uma interlocução que assumiu

${ }^{19}$ As casas editoriais em Moçambique tem sua história a partir da independência, período no qual o país pode implantá-las. Restritas à publicação de antologias poéticas e livros de contos já estampados em jornais e revistas, a cultura do romance ainda tem dificuldade de inserção no país, pois exige maior mercado para consumo do gênero. Hoje, é claro, as dificuldades são um pouco menores, em comparação ao final dos anos 1970 e durante a década de 1980.

${ }^{20}$ De acordo com Afonso (2004, p. 173),

O conjunto paratextual estabelece laços entre texto e extratexto, em função de certos aspectos fundamentais que consideram ao mesmo tempo as intenções do autor, o interesse do leitor e a sorte da obra. Atrai a atenção e estimula a curiosidade; cruza os discursos social e estético; faz-se guia de leitura e seduz pelo não-dito.

Assim, nos textos da literatura pós-colonial moçambicana, o paratexto evidencia-se como procedimento para interrogar o discurso europeu e para representar a si próprio e ao outro (AFONSO, 2004, p.172), ou como uma forma própria de intrusão no discurso escrito. Tal prática é relevante ao considerarmos o conto escrito como gênero tipicamente ocidental e que se deixa facilmente hibridizar pelo pastiche, pela paródia, por técnicas da tradição oral e pelos mitos africanos (AFONSO, 2004, p. 171). Afonso (2004, p. 173-296), inclusive, dedicou um capítulo inteiro à questão, no que tange especificamente ao conto moçambicano. 
características próprias e individuais, ou como Afonso (2004, p. 161) coloca, estórias a partir de histórias.

O contexto da guerra civil criou um empecilho à produção ficcional moçambicana, como se deu com Diário de Sangue, de Orlando Muhlanga, publicado ao início da década de 1990. A superação da crueldade da guerra, entretanto, não foi empecilho para o surgimento de geração composta por veteranos e novatos como Mia Couto, Ungulani Ba Ka Khosa, Aldino Muinga, Lília Momplé e Paulina Chiziane. Na verdade, a literatura que passaram a produzir instituiu-se em instrumento de questionamento de um país novo e "uma das pedras angulares na construção de uma identidade nacional" (SAÚTE, 2001, p. 18), prezando por denúncias de escândalos que revelam os impasses históricos, literários e políticos da nação moçambicana. A imprensa, devido aos ideais que ruíram, não é mais dedicada à literatura, apesar de que, mesmo diante de tais condições, ainda sobreviva e resista às adversidades a que é exposta hodiernamente. As décadas de 1980 e 1990, para a literatura moçambicana, abriram espaço de questionamento sobre o rumo que sua história deveria tomar, somado à problemática contemporânea acerca de um suposto pós-modernismo na cultura dominante. Se há resistência às tendências da contemporaneidade pós-nacional, como se vê na escrita de Aldino Muinga e Paulina Chiziane, caracterizadas pelo pertencimento a um lugar determinado, identificável em tempo anacrônico (NOA, 2015, p. 33), existe também a liberdade estética, subjetiva e temática, que caracteriza a reinvenção dos padrões, tanto culturais como literários, já estabelecidos e relacionados a uma atualidade "muitas vezes submersa e que representa um diálogo com as tradições e com uma determinada memória coletiva" (NOA, 2015 , p. 30). Essas narrativas curtas também não deixam de ter a sua fisionomia própria, como se observa na escrita de Ungulani Ba Ka Khosa e de Mia Couto, dedicadas à reinvenção da tradição de narrar (NOA, 2015, p. 62).

Tais tendências contemporâneas são propícias para se pensar o conto em Moçambique como parte de uma realidade total, ampliada em seus sentidos e valores comunitários, mesmo com a moderna solidão individual da vida contemporânea. 
O fragmento e a totalidade são associados a mudanças de técnicas e temáticas, cuja ordem hegemônica, e ocidental, é subvertida em seu modo de contar, fazendo com que a lógica dos acontecimentos seja mais importante do que a lógica da ação. Isso cria um efeito transversal em que os personagens não fazem o que devem fazer em razão dos poucos meios utilizados, que resultam no máximo de impressões (NOA, 2015, p. 60).

A realidade é ampliada e, então, vislumbrada

[...] no conto africano que tem claramente como referência uma sociedade holística ou comunitária, real ou imaginária, em contraposição às sociedades individualistas do mundo contemporâneo (NOA, 2015, p. 61).

Nesse sentido, o conto moçambicano e o conto brasileiro, dentro de suas singularidades, possuem relação profunda com a formação identitária nacional. Bosi (1977), em seu texto "Situação e formas do conto brasileiro contemporâneo" ${ }^{21}$, estabelece essa relação do ser social com "um traçado de eventos" (p. 8), em consonância com os percursos ditados pela forma romance, no caso do conto brasileiro, que tende para o neo-realismo de cunho ontológico. Ambas as formas narrativas, entretanto, parecem se situar, em relação ao gênero e a seus aspectos sociais e estéticos, na sincronia entre a processualidade dessas particularidades artísticas e os desafios da formação nacional.

O próximo capítulo explora a convergência desses aspectos estéticoideológicos no que tange à formação nacional figurada na contística dos autores selecionados, o brasileiro Bernardo Élis e o moçambicano Mia Couto.

${ }^{21}$ Tal texto introdutório, publicado por Bosi no livro O conto brasileiro contemporâneo (1977), em cuja organização reuniu vários contos de autores contemporâneos, muito se destaca por ser uma das maiores referências críticas em relação ao conto no Brasil. Elaborado a partir da evolução progressiva da narrativa e da crítica da natureza do romanesco no país, o artigo tem seu mérito em estabelecer a relação entre a história e o conto, o que é coerente com outra obra publicada pelo mesmo autor no mesmo ano, O ser e o tempo da poesia. Por outro lado, é indício forte da escassez de fortuna crítica e teórica dedicada ao conto, o que permanece até os dias atuais. 


\title{
2. "Até hoje: meu avô vai chispado no Ford do filho, mas vê um carro de bois, manda parar e desce" ${ }^{\text {22 }}$ : entre o arcaico e o moderno - conexões índico-atlânticas
}

\begin{abstract}
Tombado no carreiro, sobre as pedras que antes evitava, o menino olha as cimeiras paragens. Um coqueiro Ihe traz lembranças litorais. Onde há uma palmeira sempre deve ser inventado um mar, eternas ondas morrendo. Agora, rebatido no repentino solo, o menino estranha ver tanto céu. A pergunta lhe vem pastosa: porquê o chão, tão debaixo dele? Outro golpe, a bota espessa lhe levando o rosto ao encosto da terra. Fica assim, pisado, sem outra visão que a da areia vermelha. Seu pensamento se desarruma. Palmeira, palma do mar, onde o azul espeta suas raízes. Pergunta-se, com todas as devidas vénias: e se içassem não a bandeira mas a terra?
\end{abstract}

COUTO, Mia. "O poente da bandeira". In: Estórias abensonhadas. São Paulo: Companhia das Letras, 2012. p. 54.

\footnotetext{
${ }^{22}$ Versos extraídos do poema "A cachaça de meu avô", inserido no livro Primeira chuva (1971),
} de Bernardo Élis. 
Este capítulo tem o objetivo de estabelecer a interlocução entre Brasil e Moçambique, a partir da formação nacional de ambos os países, bem como detalhar a importância dos autores contemplados no corpus para com esses processos históricos, evidenciados na sua contística.

No primeiro momento, realizar-se-á essa ligação com base na experiência colonial e as conexões entre nação e literatura. No segundo, explorar-se-ão os impasses da formação nacional brasileira em consonância com o desenvolvimento do estado de Goiás, de modo que se justifique o surgimento de Bernardo Élis neste contexto. No terceiro, por sua vez, detalharse-ão os impasses da configuração nacional moçambicana, de maneira que se esclareça a conjuntura histórica de surgimento da obra de Mia Couto.

\section{1. "Só quero lembrar se o tempo for todo meu"23: a relação com o império}

A atuação de uma tradição literária portuguesa em colônias com povos de diferentes etnias, caracterizadas por línguas, costumes, culturas e religiões próprios, de acordo com o crítico brasileiro Antonio Candido (1987, p. 164-165), veio a suscitar como resultado final a expressão de novas realidades, por meio das suas respectivas literaturas nacionais. $\mathrm{Na}$ verdade, considerando $\mathrm{O}$ exemplo brasileiro,

Historicamente a literatura do período colonial foi algo imposto, inevitavelmente imposto, como o resto do equipamento cultural dos portugueses. E este fato nada tem de negativo em si, desde que focalizemos a colonização, não pelo que poderia ter sido, mas pelo que realmente foi como processo de criação do País, com todas as suas misérias e grandezas (CANDIDO, 1987, p.176).

O que foi o processo colonizatório nas ex-colônias, que constituíram o império português, entretanto, gera um sentimento de "[...] incerteza se o passado é de fato passado, morto e enterrado, ou se persiste, mesmo que

${ }^{23}$ Estrofe extraída do poema "Lembrança", inserido no Tradutor de chuvas (2011), de Mia Couto. 
talvez sob outras formas [...]" (SAID, 2011, p.34). Afinal, há um potencial acúmulo de tensões impressas ainda hoje nas relações sociais das ex-colônias portuguesas, mesmo após suas independências, conforme atesta o historiador e escritor moçambicano João Paulo Borges Coelho (2003, p.175-176), no que tange principalmente a Angola, Guiné-Bissau e Moçambique. O estado colonial, inserido no império português, fez com que mesmo durante

[...] A tendência da globalização para um mundo sem fronteiras, não obstante, não implica desconsiderar a existência concreta desse mesmo Estado e seus instrumentos de poder, que continuavam e continuam a atuar na vida social. (ABDALA JUNIOR, 2007, p.19)

A literatura e a cultura, ligadas aos processos de formação nacional, exerciam poder de forma a atestar a subalternização do outro, tornando-se instrumentos de cunho civilizacional que mais enalteciam os poderes metropolitanos e, por consequência, diminuíam os sujeitos colonizados. A negação dos valores locais destaca a crueldade do processo colonial. Porém, apesar do caráter atroz que a colonização pode assumir desde sua fase mercantil até o sistema de corporações multinacionais com o neocolonialismo, admite-se que 0 caráter total desse processo pode ser assumido e problematizado, considerando as literaturas pós-coloniais, na concepção do moçambicano Francisco Noa (2016, p. 30-31), sendo que a quebra da rigidez dos valores coloniais é necessária a um progresso do gênero humano ${ }^{24}$, seja por parte de quem foi colonizado, seja por parte de quem foi colonizador. Como afirma Noa,

Quer para os que colonizaram quer para os que foram colonizados, revisitar as criações de espírito que têm a ver não só com um determinado segmento da história que os ligou, como também com todo um imaginário que subsiste sob formas mais ou menos elaboradas, mais ou menos dissimuladas, torna-se um imperativo que tem tanto de moral como de pedagógico [...] (2016, p. 31)

Um reexame histórico deve

[...] considerar outras possibilidades de consciência e de conduta, em que, por exemplo, a dicotomia do bem e do mal ganha novos particularismos. E, é assim que, cada uma dessas sociedades, dada a abertura que, de modo virtual ou efetivo, aí se desenvolve, consegue viver e enfrentar os processos traumáticos e moralmente condenáveis que ela própria desencadeou, protagonizou ou sofreu ( $p$. 31).

\footnotetext{
${ }^{24}$ Essa expressão é própria da concepção humanista do marxismo, da qual o caráter social da personalidade humana determina o aspecto histórico da obra de arte, de acordo com Celso Frederico (2013, p. 137), com base na teoria estética marxista de György Lukács.
} 
Afinal, a divisão imposta entre colonizados e colonizadores, inseridos num plano cultural de ordem imperialista, conforme a coesão de tal domínio, é reverberada nas interpretações tanto de uns como de outros "[...] tendo se introduzido na realidade de centenas de milhões de pessoas, na qual sua existência como memória coletiva e trama altamente conflituosa de cultura, ideologia e política ainda exerce enorme força" (SAID, 2011, p. 46). A cultura que alimentou o sentimento e a lógica imperialista deve ser analisada com 0 máximo de cuidado, uma vez que a resposta à violência do processo colonial se dá com a mesma força mas de diferentes maneiras.

Pensar o conto como figuração do arcaico e o moderno, considerando a sua tradição oral e a sua escrita moderna, faz desses polos essenciais à compreensão da contística dos autores aqui apresentados: Mia Couto e Bernardo Élis. Isso não se restringe, é claro, à diferença entre as nações, culturas e sistemas literários a que pertencem, pois dão o contorno das transformações históricas do momento da escrita, da tradição em que se inscrevem e da sua junção à história nacional; e, por que não, mundial.

A modernidade, associada ao desenvolvimento do capitalismo, tem como resultado os países ditos desenvolvidos e os subdesenvolvidos, numa configuração ainda em destaque nos dias de hoje. Suas influências ocorrem não só na formação das nações, mas também na relação do homem com a sua própria história. Ao tempo em que a modernidade se instaura, o homem passa a distanciar-se de uma visão totalizante da realidade, que define o espírito absoluto, nos termos de Lukács (2011, p. 54), e a arte adquire autonomia em relação a outros modos de ver a realidade, como a ciência, a religião e a filosofia. Apesar da independência então adquirida da arte, a distância desta em relação aos outros domínios é sinônimo de alguma perda.

O progresso, então, tem seus contrapontos. O mesmo acontece com o conto, cujas tradições não podem manter os similares elementos performáticos e coletivos, por necessidade de ceder espaço à autoria, à individualidade e à imanência da escrita. $O$ mesmo se verifica em relação às cidades, cujo modo de organização ascendente é sinônimo de modernidade. Outra e decisiva característica para esse tipo de progresso é que ele não ocorre para todos, 
mas somente para aqueles que detêm os meios de produção, por conseguinte, os meios para a sua realização artística.

A divisão entre países desenvolvidos e subdesenvolvidos não acontece ao mero acaso. As relações entre o centro do Ocidente e aqueles que sofrem sua influência permitem que o escrevente da história mundial, papel geralmente interpretado pelas classes dominantes, exerça interferência no ordenamento da vida social constatada até mesmo em níveis epistemológicos. Tal verificação, entretanto, não permite visualizar exatamente os impasses que movem tais definições. Um dos maiores talvez seja a questão colonial, que,

Segundo a sua demonstração, se reveste de dois aspectos: o de um
"regime de exploração desenfreiada de imensas massas humanas
que tem a sua origem na violência e só se sustém pela violência", e o
de uma "forma moderna de pilhagem". Sendo o genocídio a lógica
normal, o colonialismo é portador de racismo. E é nesta gigantesca
cartasis colectiva que o colonialismo desciviliza simultaneamente o
colonizador e o colonizado (ANDRADE, 1978, p. 7).

Essas gerações, nas palavras de Cesáire (1978, p. 13), definem que uma civilização "incapaz de resolver os problemas que seu funcionamento suscita, é uma civilização decadente". Enquanto que "essa Europa acusada no tribunal da 'razão' como no tribunal da 'consciência', se vê impotente para se justificar; e se refugia, cada vez mais, numa hipocrisia tanto mais odiosa quanto menos susceptível de ludibriar" (CESÁlRE, 1978, p. 13), com foco nas estratégias de dominação cristãs que abomina (cristianismo = civilização, paganismo = selvageria), Cesáire pergunta-se até que ponto o contato com a Europa, em sua lógica de superioridade inatacável, foi bom para os países colonizados. Ele responde que

[...] da colonização à civilização a distância é infinita; que, de todas as expedições coloniais acumuladas de todos os estatutos coloniais elaborados, de todas as circulares ministeriais expedidas, é impossível resultar um só valor humano (CESÁlRE, 1978, p. 16).

Dito isso, a experiência após o fim da colonização, cujo processo fora interrompido pela independência, fez com que a modernidade chegasse para vários povos e nações, cuja conexão com o cenário internacional fez-se tardiamente pela então velha lógica de nação. O que é sinônimo de modernidade, em sua conquista, faz-se identidade do atraso e da disposição subalterna do país em relação à economia mundial. 
Um dos modos para se pensar as relações entre o arcaico e o moderno se faz pela dialética entre localismo e cosmopolitismo, sendo que o dado local, marcado na forma estética pela expressão, faz comunicação com a forma da tradição europeia, da qual a literatura brasileira, entre outras, originárias do estatuto colonial, a princípio, fez-se imitar (CANDIDO, 2010, p. 117).

Existem diversas maneiras de tratar essa dialética, cujo resultado de equilíbrio é a obra literária. Mas a tensão entre o dado local e os moldes europeus é o eixo principal para problematizar essas questões, que dizem respeito à superação, principalmente ao intelectual subalterno, de questões como meio, raça e história, fazendo constantes os conflitos entre o coletivo e o individual, não deixando de evidenciar os impasses ainda presentes, em razão da relação com o colonizador (CANDIDO, 2010, p. 118-119).

De um lado, encontra-se o Brasil, país extenso e de independência tardia em relação aos países latino-americanos, exemplo loquaz da modernização periférica em área subdesenvolvida, cenário da obra de Bernardo Élis. De outro, acha-se Moçambique, país africano cuja modernidade precária, também inspirada no modelo europeu, vem, a duras penas, adquirindo contornos identitários próprios, visíveis na produção de Mia Couto.

\section{2. "Foi em Goiás que se deu, faz tempo, meu avô me contava"25: o Brasil de Bernardo Élis}

Mesmo diante do novo fenômeno do crescimento das cidades, a partir da década de 1930, pouco antes da abertura democrática, com o fim da ditadura Vargas, Bernardo Élis publica Ermos e gerais (1944), livro em que consta o seu belíssimo conto "Nhola dos Anjos e a Cheia de Corumbá", publicado anteriormente na revista Oeste $^{26}$. A percepção de Bernardo Élis

\footnotetext{
${ }^{25}$ Versos extraídos do poema "Romance do soldado músico", inserido no livro Primeira chuva (1971), de Bernardo Élis.

26 Revista fundada pelo autor e um grupo goiano de artistas e intelectuais, em 1942. Inicialmente tinha caráter apenas literário, e depois se dedicou à divulgação cultural. O primeiro número não estava sintonizado com os princípios político-ideológicos do Estado Novo, o que realça mais a efervescência ideológica da época marcada pelo deslocamento da capital da cidade de Goiás para a moderna capital Goiânia, fato ocorrido em 1933. O crescimento espiritual da nova classe média goiana, entretanto, ainda sofria grande descompasso em relação ao desenvolvimento urbano acelerado do país, .
} 
diante do fenômeno da urbanização acelerada do Brasil foi um fator importante para a sua produção literária. Diz ele que

\begin{abstract}
O problema da temática é sério. O sertão mudou muito. Tenho uma teoria, talvez um pouco exagerada, porque eu sou exagerado nas coisas: a favela do Rio de Janeiro hoje é mais sertão do que o lugar mais afastado de Goiás. A lavoura está em grande parte mecanizada. O roceiro agora consome quase tudo da cidade - ele já não produz quase nada. A alteração foi grande... As populações rurais foram para as periferias urbanas. Eu tenho a impressão de que hoje a minha literatura deve se deslocar para as periferias urbanas. É lá que se encontram as populações carentes e portadoras de uma cultura tradicional - que é a cultura em que se baseia a minha literatura (ÉLIS, 1983, p. 12).
\end{abstract}

Élis, coincidentemente, perspectiva a universalização do sertão, possível por meio da literatura de Guimarães Rosa e reconhecível pelo estudo realizado por Antonio Candido, como um terceiro estágio da consciência trágica do subdesenvolvimento (CANDIDO, 1987, p. 161-162). Este fenômeno contrasta com o processo da urbanização brasileira, das migrações das regiões pobres mais afastadas às grandes metrópoles. Depois das atenções serem voltadas à realidade local (CANDIDO, 1987, p. 159) por intermédio do romance e do conto da década de 1930, cumpriu-se ao estágio do super-realismo a tarefa de localizar a particularidade expressa na literatura regionalista como que ligada à totalidade do mundo, por meio da explicitação das condições atrozes do subdesenvolvimento, o que resulta numa universalização da região, tanto em nível temático, já declarado aqui por Élis, quanto linguístico e alegórico-simbólico.

$\mathrm{Na}$ verdade, segundo Rogério Santana dos Santos (2004, p. 59-60), tomar o regionalismo de Élis, munido de potencial autoconsciência, também é motivo para se pensar a experiência colonial, as condições locais e as relações entre o urbano e o rural. Isso possibilitou ao crítico goiano realizar um estudo riquíssimo a partir de contos de dois autores referência nas letras do Brasil central: Hugo de Carvalho Ramos, que fora responsável por incorporar Goiás à vida literária nacional, e Bernardo Élis, cujo trunfo é ter chamado a atenção dos olhos da crítica antes fechados para a literatura de inspiração modernista, produzida no estado de Goiás.

Conhecido por ser o primeiro literato de Goiás a ocupar uma cadeira na Academia Brasileira de Letras, Élis sempre teve interesse em destacar o 
estado do resto da federação (FREDERICO, 2005, p. 124). Além de escritor, foi advogado, professor e historiador. Sua atuação, entretanto, também se manifesta no exercício político, o que era ato corriqueiro numa época em que as demandas democráticas em plena ditadura Vargas tinham como carro chefe a célebre Coluna Prestes (FREDERICO, 2005, p. 121). O apreço pela cultura e pela história de um estado "apartado" do restante do país era essencial para a superação daquele status quo.

Sendo o nosso modernismo um dos dois momentos decisivos para a inteligência brasileira (o primeiro foi o romantismo), o debate cultural acerca das realidades mais típicas e contraditórias do país encontra seu ponto crucial na rebeldia ostentada por certos intelectuais comprometidos ${ }^{27}$ (CANDIDO, 2010, p. 119-120). Na produção literária, são revelados os problemas sociais por meio da tensão entre a região e a nação, o local e o universal

Em lugar do idealismo vagamente esotérico e decadente veremos um apelo às camadas mais profundas do inconsciente coletivo e pessoal. O nosso Modernismo importa essencialmente, em sua fase heroica, na libertação de uma série de recalques históricos, sociais, étnicos, que são trazidos triunfalmente à tona da consciência literária. Este sentimento de triunfo, que assinala o fim da posição de inferioridade no diálogo secular com Portugal e já nem o leva mais em conta, define a originalidade própria do Modernismo na dialética do geral e do particular (CANDIDO, 2010, p. 126-127).

Tal ato faz com que aspectos tratados como relacionados à realidade nacional sejam revisados de forma diferenciada, como a questão do negro na literatura brasileira, que fora incorporado à cultura local durante o movimento modernista, depois de ter sido negligenciado no período romântico. O mesmo se dá com a questão revigorada do índio, do trabalho assalariado, da mulher, etc. O nacionalismo move-se do plano estético para o plano político, ao destacar, como no exemplo anterior, que

Não se ignora o papel que a arte primitiva, o folclore, a etnografia tiveram na definição das estéticas modernas, muito atentas aos elementos arcaicos e populares comprimidos pelo academicismo. Ora, no Brasil as culturas primitivas se misturam à vida quotidiana ou são reminiscências ainda vivas de um passado recente (CANDIDO, 2010, p. 128).

27 Refere-se aqui às duas tendências presentes no nacionalismo romântico brasileiro, apresentadas por Antonio Candido (2010, p. 119-120). A primeira volta-se à superação da influência portuguesa a partir da afirmação da peculiaridade literária brasileira. A segunda desconhece totalmente Portugal, não indo além da conversa de salão e dos modelos franceses. Essas propensões são importantes para se pensar a instauração da dialética do particularismo e do cosmopolitismo na literatura brasileira. 
Ao passo em que a dinâmica de nossa vida espiritual adquire aspecto cada vez mais particularizado, verifica-se uma natureza conflitante entre tais fenômenos da memória histórica, que dizem respeito ao arcaico e ao moderno, em nossa formação nacional. Prova disso é a narrativa de Bernardo Élis, em cujos contos é possível manter um diálogo com a estrutura tradicional, com

[...] contos de corte moderno, com jeito de crônicas, mais descrição que narração ou então sugerindo mais que escrevendo e com imagens surrealistas que apontam para o fantástico, numa bela negatividade que leva de imediato à poesia (TELES, 2015, p. 10).

O mencionado crítico (2015) explana que a obra de Élis, na possibilidade de ser analisada por meio de critérios como "a descrição, o ponto de vista, o espaço, o tempo e a própria configuração dos personagens, além da variação de perspectiva ideológica com que os temas são abordados de livro para livro" (p. 14), também pode ser representação da própria transformação cultural, processo no qual a dialética entre o velho e o novo são elementos bastante destacados. Esse procedimento dá contorno a um regionalismo que diz respeito não somente ao local, mas que também "é ênfase acentuada na cultura plantada no espaço rural, moldada pela percepção coletivizada de que o regional quer romper seus limites em relação à cultura nacionalizada" (SANTOS, 2004, p. 12), o que faz da língua, do espaço e dos usos e costumes aspectos essenciais para a afirmação do elemento regional diante do universal.

O subdesenvolvimento, entretanto, faz da organização sócio-políticoeconômica da sociedade brasileira um traço fundamental para o entendimento de tal estado de coisas (SANTOS, 2004, p. 56). Para uma compreensão total, entretanto, é necessário pensar o processo colonizatório, que envolve a base que "sustentou o mundo moderno, a nova ordem dominante que integra a todos" (PRADO JR., 2011, p. 15).

Considerando a extensão do território, o que acarretou na distribuição irregular da população em núcleos esparsos (PRADO JR., 2011, p. 34), a posse do litoral veio primeiro, o qual acabou por se tornar mais populoso. Os vários obstáculos não auxiliaram na interiorização do país, o que só ocorreu durante o século XVII, em razão de uma economia baseada na monocultura de exportação. Se Sérgio Buarque de Holanda caracteriza a expansão como irracional (HOLANDA, 1995, p. 43), a colonização portuguesa é tida por Caio 
Prado Junior (2011) como circunstancial, uma vez que "sofreu as contingências fatais criadas pelo conjunto das condições internas e externas que acompanham a obra aqui realizada por ela" (p. 123-124).

A especificidade brasileira resulta de traço característico do mercado europeu, tendo em consonância as "conveniências da produção e do mercado" (HOLANDA, 1995, p. 47), e sua inserção no Brasil foi possível pela abundância das terras, o que fez das propriedades rurais as unidades básicas de produção, de modo que o cultivo de gêneros agrícolas em grande quantidade era uma demanda da Europa, principalmente de produtos naturais oriundos das regiões de clima quente.

Os rios, canais de comunicação por excelência, garantem fácil acesso ao interior (PRADO JR., 2011, p. 39), inclusive para desenvolvimento do comércio. Na verdade, a agricultura, a pecuária e a mineração se destacam como atividades exercidas durante o período colonial, tendo a agricultura brasileira proeminência até hoje no mercado internacional.

A agricultura se mostrou um problema para aqueles que vieram administrar os trópicos, sublinhando-se as inadequações técnicas que caracterizaram o manejo das novas terras como um ambiente menos propício aos seus propósitos, ou que também definem o português como ineficiente para atender às próprias demandas da colônia e da metrópole. Diz o sociólogo Sérgio Buarque de Holanda (1995) que, na figura da monocultura, "nessa exploração, a técnica europeia serviu apenas para fazer ainda mais devastadores os métodos rudimentares de que se valia o indígena em suas plantações" (p. 49), o que fez necessária a presença da mão-de-obra escrava negra. Essa configuração também reflete o tipo de colonização escolhido (PRADO JR., 2011, p. 123), que exigia a extração a partir do solo rico, sem grandes sacrifícios (HOLANDA, 1995, p. 52). Ainda assim, fez com que houvesse uma mobilidade permanente e considerável do interior para o litoral, o que demandou a constituição de novos centros decisórios. A atividade se manteve sob as bases do trabalho escravo, da monocultura e do latifúndio. Em estrutura similar, a pecuária fez com que o povoamento fosse dado contiguamente em fazendas de gado, o que acelerou o processo (PRADO JR., 2011, p. 56). Ambas as atividades eram voltadas ao mercado externo e não 
refletiam, de fato, a economia colonial brasileira, e sim as "atividades subsidiárias destinadas a amparar e tornar possível a realização das primeiras" (PRADO JR., 2011, p. 128).

A mineração fazia de suas potenciais regiões nada favoráveis à agricultura e à pecuária (PRADO JR., 2011, p. 57). Destinada a abastecer regiões distantes, a mineração moveu uma das maiores parcelas da população, atraindo inclusive a atenção dos jesuítas. Sua organização, idêntica à agricultura, ocorre em larga escala, mas a presença de indivíduos com interesses volúveis foi suficiente para iniciar a decadência e a extinção da atividade mineradora.

Com a queda na mineração, as áreas de Mato Grosso e Goiás são as mais atingidas, diferente do que ocorre em Minas Gerais. A extrema complexidade de correntes migratórias e fluxos econômicos acabam por gerar um novo equilíbrio político durante o império (PRADO JR., 2011 p. 87), cujo efeito, em larga escala, é a criação de um mercado doméstico (PRADO JR., 2011, p. 130). Na verdade, a produção interna continua atendendo às demandas do mercado internacional, mas explora de maneira "extensiva e simplesmente especuladora, instável no tempo e no espaço, os recursos naturais do país" (PRADO JR., 2011, p. 134)

Goiás, em especial, fora caracterizado por seu não-desenvolvimento em relação ao litoral, durante a colonização até a fase imperial ${ }^{28}$, em razão de questões administrativas decorrentes da decadência do ouro. Na verdade, o equívoco está em não se considerar a irracionalidade do processo colonizatório por parte dos portugueses, pois estes agiram "antes com desleixo e certo abandono", conforme explana Sérgio Buarque de Holanda (1995, p. 43). A administração e o controle das terras goianas não foram realizados, durante a colônia, de maneira simétrica e uniforme, traços esses que caracterizam a forma de organização precária. Ainda, devido à alternância entre Minas Gerais e São Paulo (CAMPOS, 2003, p. 15), regiões de maior prestígio econômico, as

${ }^{28} \mathrm{O}$ desenvolvimento do estado de Goiás só pode ser constatado efetivamente a partir da década de 50. Até então, havia uma ilusão de desenvolvimento a partir do ouro, que fora superado rapidamente, e também do ciclo do gado. A ilusão do último aspecto citado é destacada na obra de Élis. 
penosas condições em que foi deixado o estado de Goiás somente contribuíram para a manutenção das oligarquias no estado.

A administração centralizada, a partir da capital, muitas vezes quase inacessível pelo vasto território, nada criou de novo para a colônia (PRADO JR., 2011, p. 320), devido ao uso de uma organização similar à da metrópole. Ao modelo do reino, pequenos núcleos se tornaram centros administrativos, mas que ainda não faziam do Brasil uma unidade. Por isso, julgar tais processos com foco na lógica entre litoral e sertão se faz necessário para pensar nas relações do país com a sua história e sua modernização precária.

A constituição das capitanias hereditárias tornou-se, a começar pela administração de cada uma, um complexo heterogêneo de reinos (PRADO JR., 2011, p. 322) cuja divisão se fez entre principais e subalternas. A confiança e a autonomia, associadas à distância da colônia com relação à metrópole, entretanto, nunca penetraram nos processos de administração da colônia, o que culminou no tráfico de ouro mesmo diante da dureza das mesas de inspeção, que recebiam ordens diretas da coroa para recebimento e avaliação do minério.

Em níveis políticos, a atuação do governador, representante do executivo, com o poderio militar e a atuação cúmplice da justiça, fortaleciam as relações entre as demandas e o governos, a níveis local e geral, ocorrendo influência entre os poderes e também de conselhos e ordens diversos. Os serviços de milícia e ordenanças mantinham-se aliados ao governador em razão de sua instrução militar, o que nos faz pensar no tato com que este exercia a sua gestão.

Durante o Império houve a regulação minuciosa e casuística de alguns assuntos, mas tais leis eram geralmente vinculadas à corte. Isso tornava o espaço fora da última uma terra absolutamente sem lei, diferente da capital, onde havia a maior concentração de legisladores do que em comparação aos estados que representavam. Ainda, poucos destes eleitos provinham do sertão ou das pequenas cidades.

A Primeira República foi um período marcado pelo processo de modernização baseado nas condições coloniais pouco modificadas durante 0 
Império para um período democrático no qual o federalismo assumiu importante aspecto diferenciador nas relações políticas.

A transição do unitarismo para o federalismo, muitas vezes atrasado por aspectos que diziam respeito à manutenção dos centros oriundos do passado, ainda ligados ao capital internacional pela agroexportação, assumiu no campo da cultura/literatura um papel decisivo de unidade e identidade. Esses são marcos presentes no movimento modernista em sua primeira geração, e conscientização acerca do subdesenvolvimento e das condições de progresso perspectivadas pela segunda geração. Entretanto, apesar da inserção do estado de Goiás nos meios modernos de transporte, relacionada à dinâmica do mercado nacional, esta conjuntura acentuou como a economia goiana "permaneceu articulada de forma extremamente periférica no mercado capitalista do Brasil" (SILVA, 2005, p. 39). Formas sociais como o agregado continuam vinculadas ao latifúndio como, em termos econômicos, um semiescravo. Ainda, o domínio dos proprietários de terra era estendido "a todos os níveis da sociedade, com base nos mecanismos de funcionamento do coronelismo e do pacto oligárquico" (SILVA, 2005, p. 43).

O coronelismo, sendo forma de excelência do mandonismo local, se mostra também um sistema propício à manutenção conveniente da decadência do estado de Goiás, cujos benefícios somente atingem os latifundiários, políticos e militares. Esse sistema de dominação vem desde a organização unitarista do estado brasileiro, que também diz respeito aos meios utilizados para penetração e exploração no interior da colônia, um dado que prova que os problemas advindos dessa organização ainda se mantêm irresolutos em sua maioria. Retomando Aimé Césaire (1978) acerca da decadência civilizacional (p. 13), também é possível perceber que "uma civilização que prefere fechar os olhos aos seus problemas mais cruciais, é uma civilização enferma. Uma civilização que trapaceia os seus princípios, é uma civilização moribunda" ( $p$. 13).

No caso da classe dominante brasileira, há de se concluir que não representa de fato a todos por trair os seus princípios, fazendo a si mesma indolente; no caso do proletariado, que fica ao jugo maior da primeira em todas as esferas do estado moderno, ao ignorar ou não ter consciência em relação 
aos seus maiores problemas e direitos. A luta pela consciência dessa classe é a aposta da literatura de Bernardo Élis.

O problema do proletariado e o da colonização permaneceram irresolutos por parte da Europa, o que tende a fórmulas de capitalismo extremo, cada vez mais próximos da lógica de níveis de desenvolvimento em classificação genética, como é apresentado na obra de Huxley Admirável mundo novo (1932). A partir dessa lógica, o colonialismo vincula-se à barbárie de forma a poder, "em qualquer momento, desembocar a negação pura e simples da civilização" (CÉSAIRE, 1978, p. 21). Se por um lado há o progresso $^{29}$, por outro Césaire fala

[...] de sociedades esvaziadas de si próprias, de culturas espezinhadas, de instituições minadas, de terras confiscadas, de religiões assassinadas, de magnificências artísticas aniquiladas, de extraordinárias possibilidades suprimidas (1978, p. 25).

O estudioso ainda completa dizendo que o que definiu o processo de colonização foram os seus instrumentos (CÉSAIRE, 1978, p. 28), cuja projeção estatal culminou em duas resoluções apenas: direito e luta. Entre esses dois extremos encontram-se os contos de ênfase social de Bernardo Élis.

Em sua figuração realista, o contista goiano contrapõe modelos tradicionais aos novos, fazendo de sua técnica um sinônimo de engajamento, ao recriar artisticamente a realidade goiana, nas palavras do crítico goiano Gilberto Medonça Teles (2015, p. 11), numa tentativa de contrapor-se ideologicamente à realidade vigente.

Bernardo Élis faz das formas míticas e do contraponto tensionado entre as estruturas sociais, figuradas por representantes do coronelismo e por aqueles que são subjugados por eles, um modo de se pensar a história, cujo progresso privilegiado a alguns privou as populações mais carentes de sentido histórico e humano totalizantes. Essas questões não se encerram somente às dimensões físicas do país, mas se expandem na preocupação de Élis ao dedicar sua escrita, cuja matéria prima é a oralidade e o conhecimento populares, justamente àqueles que migram de tais regiões para as grandes

${ }^{29}$ Cesáire (1978) diz que, na época em que escreveu Discurso sobre o colonialismo, a barbárie burguesa por parte dos colonizadores se media pelas virtudes cristãs a favor de uma disputa de honra, "de que a crueldade, a mentira, a baixeza, a corrupção contaminaram maravilhosamente a alma da burguesia europeia" (p. 31). 
metrópoles, bem como os despossuídos, os esquecidos do progresso material. Assim, a construção da capital do estado, Goiânia, seria o principal marco motivador para as transformações em sua região, com reflexos em sua contística.

Em Ermos e Gerais, de 1944, é revelado o sertão mitificado de encontro com a dureza da realidade aniquiladora. Em "A mulher que comeu 0 amante", pode-se perceber que a vida humana não escapa à praticidade dos instintos da fome e da miséria, num ambiente hostil que acaba por projetar figuras de configuração própria, como o "O louco da sombra", marginalizado pelo amor não consumido; e também por separar os elementos estranhos de um ambiente desesperançoso, como em "Papai Noel ladrão". O ofício familiar do trabalho com a terra, que fora devastado pela enchente, é mote de "Nhola dos Anjos e a cheia de Corumbá", em que o final do ciclo do gado e a permanência da propriedade privada se fazem motivos para a decadência da família atada a uma terra sem futuro.

Acerca dos impasses oriundos do período da República Velha, defende o crítico Rogério Santana dos Santos (2004) que

Do ponto de vista da moral religiosa, [...] a crueldade dos sertanejos ganha dimensões de inexistência. Ela só deixa de existir no plano da concepção moral, não na história, pois nesta a brutalidade reinou na formação do homem brasileiro (p. 119).

Tais argumentos críticos justificam que "a violência surge das fibras do manto social pobre que encobriu o ruralismo brasileiro" (SANTOS, 2004, p. 119), de forma a identificar Ermos e gerais como atualização estética de um impasse histórico secular, como instrumento de denúncia das atrocidades ainda presentes contra o homem do campo. Se isso diz respeito a uma cultura relegada a níveis inferiores no plano nacional, característica do subdesenvolvimento que se faz marca d'água do estado de Goiás durante a primeira parte do século $X X$, também significa que a revolução modernista não conseguiu romper de imediato com a tradição literária no estado de Goiás ${ }^{30}$. Isso torna a descrição em Bernardo Élis fundamental (SANTOS, 2004, p. 120),

\footnotetext{
${ }^{30}$ Isso ocorre em razão desta tradição se ater muito ao pitoresco romântico, em evidente queda gradativa antes e depois da literatura de Bernardo Élis, cuja inovação temática e linguística revitalizou o regionalismo goiano e brasileiro. Constata-se que até mesmo na obra de Hugo de Carvalho Ramos o lastro cultural do pitoresco ainda tinha um resíduo de força (SANTOS, 2004, p. 119-120).
} 
mas não deixa de evidenciar o ciclo de gado como ilusão de desenvolvimento esperado, embora nunca concluído, tal como a promessa de modernização do estado. Apesar da incoerência estilística entre os contos de Ermos e gerais, essa obra é fundamental para delimitar o estilo do autor (SANTOS, 2004, p. 121).

Alguns anos depois, Bernardo Élis publicou um outro livro inédito de contos, Caminhos e Descaminhos, em 1965. Se o autor fora deveras influenciado pelo movimento modernista em seu primeiro livro, mais atento à questão linguística e aos temas, seu segundo livro de contos inova o seu repertório no trato da matéria e no uso da técnica. Ainda, o tom de seus contos, cujo predomínio era do humor negro, cede lugar a sutilezas e divagações. Teles assim o justifica: "O golpe militar de 1964 teve alguma responsabilidade nisto, pois apavorou críticos e até mesmo Bernardo Élis que nem pode revisar as provas de seu livro, o que foi feito às escondidas por outrem" (TELES, 2007, p. 68). O uso de onomatopéias e efeitos fonéticos, assim como a alternância de cenas, evidenciam e intensificam os fatos e eventos inventariados.

A decadência retorna, ao destacar 0 isolamento do estado e a simbólica divisão de culturas com Tocantins (SANTOS, 2004, p. 144). No conto "Em que entram um judeu, dois baianos, alguns goianos e umas criações", a tentativa das figuras evidenciadas pelo título de obter diamantes e angariar riqueza fez com que se distanciassem de suas famílias, ficassem na miséria e, apesar de um movimento ou outro, não mudaram a lógica marcante da pobreza e do atraso. Essa narrativa, mais longa que as outras do livro, tende a pormenorizar as desconfianças e as crenças entre os personagens, reproduzindo as dinâmicas de um mercado interno que continua atendendo às demandas do mercado internacional, mas explora de maneira "extensiva e simplesmente especuladora, instável no tempo e no espaço, os recursos naturais do país" (PRADO JR., 2011, p. 134).

Tal exploração é vista também em "Quadra de São José", mas com a crítica às pontes e às estradas mal acabadas, uma vez que o principal produto do estado - o boi - entrara em decadência, e o estado consequentemente. $O$ coronel, salvo por seu animal de montaria, ao passar por uma estrutura arcaica de madeira, prestes a ruir, dá privilégios ao animal, declarado "burro de fiança" 
(ÉLIS, 1965, p. 16). A narrativa, contada como um causo ${ }^{31}$, nos faz pensar sobre os problemas da agricultura para aqueles que vieram administrar os trópicos, revelando-se as inadequações que puderam caracterizar o uso inapropriado das novas terras (da colônia) como um ambiente menos propício aos seus propósitos, ou que também caracterizam o português como ineficiente para atender às próprias demandas da colônia no passado. Assim, o referido conto é a revivescência histórica de um nefasto legado.

A organização da terra e do trabalho, oriundos da experiência colonial, aparece no terceiro livro de contos de Élis. Veranico de Janeiro (1966), a princípio preparado como romance e reestruturado como livro de contos, é atualização expressiva do autor e marca maior de seu compromisso social, explorando inclusive o grotesco e o desumano para tal intento em sua estética neorrealista.

A focalização dos personagens é o principal recurso utilizado para realçar a condição social e o plano psicológico dos personagens (SANTOS, p. 147), o que, na percepção do crítico Rogério Max Canedo Silva (2016), "[...] acentua sua capacidade de recuperação dos tipos humanos de Goiás" (p. 124). "A enxada", o mais emblemático de seus contos, é um dos que atestam a destruição causada pelo processo colonizatório e a perpetuação de sua velha estrutura, apesar dos novos meios que faz com que a exploração se perpetue. A busca de Piano, empregado do coronel Elpídio, por uma enxada para realizar o seu ofício, mesmo com a ferramenta negada pelo próprio patrão, mostra-se um drama trágico, em que o indivíduo se deteriora com esse processo de exploração desumano em que se reifica e se conforma com a pobreza e o medo. Essa situação não causa empatia nos centros urbanos, cúmplices da morte de um sujeito que é aniquilado injustamente.

Houve, ainda, algumas coletâneas organizadas pelo autor, além de outras preparadas por estudiosos da área ${ }^{32}$. Élis escrevera contos até o fim de

${ }^{31} \mathrm{O}$ causo diz respeito ao ato de contar estórias ligadas "à vida rotineira ou às fantasias populares" (COELHO, 1998, p. 122). Por estar associado à experiência pessoal, o acontecimento narrado também pode ser associado à autoria.

32 Dos livros de contos organizados pelo autor, destacam-se Caminhos dos Gerais (1975), uma reorganização de seus contos de Ermos e Gerais, e André Louco (1978), cuja novela-título abre a coletânea. Depois, Élis retorna ao conto em 1984 com Apenas um Violão, obra também aberta pela novela-título. Optou-se aqui em privilegiar Ermos e gerais, Caminhos e descaminhos e Veranico de Janeiro por fazerem jus ao projeto de Élis e também por melhor 
sua vida, mas sua morte o impediu de publicar alguns. Assim, surgiu Onde canta a Seriema, publicado em 2005, ano em que Luiz Gonzaga Marchezan, a quem coube a organização da coleção "Contistas e cronistas do Brasil", da editora Martins Fontes, preparou uma cuidada reedição de Ermos e Gerais. O prefácio enfatizou o papel de Élis como intelectual militante e sua escrita comprometida com as reformas sociais e com as "mais antigas tradições da prosa de ficção" (TELES apud MARCHEZAN, 2006, p. XXIX), produzindo, assim, um conto moderno, sem sombra de dúvidas, capaz de questionar os descompassos que movem as transformações históricas, inclusive no âmbito da linguagem, da notação espacial, dos usos e costumes, dos valores, mas que se afirma, acima de tudo, realista no trato da matéria local.

\title{
2.3. "Dentro do guerreiro vivia, eterna, a guerra" ${ }^{33}$ : o Moçambique de Mia Couto
}

A literatura de Mia Couto é predominantemente rural e, mesmo assim,

\begin{abstract}
A literatura por ele produzida tem como horizonte de expectativa muito mais o leitor não-africano, sentindo o escritor, por esse motivo, a necessidade de explicar e situar o lugar da literatura numa sociedade, como outras do chamado Terceiro Mundo com alto índice de analfabetismo. Tal condição impede a formação mais consolidada de um público leitor local (FONSECA; CURY, 2008, p.23).
\end{abstract}

A inserção da literatura moçambicana no sistema-mundo é possível, também considerando a relação do país com o capitalismo internacional, a partir da escolha de uma língua que também está de acordo com o projeto da FRELIMO para a nação moçambicana, desde a independência até a sua supremacia após a guerra civil. A opção política pela língua portuguesa evidencia a diferença cultural e linguística entre os diversos povos que

representar a "[...] desagregação do mundo rural" (SANTOS, 2004, p. 147) que tanto caracteriza a sua literatura de compromisso social.

Dos livros organizados por estudiosos, entretanto, há de se destacar a figura de Gilberto Mendonça Teles. Este crítico organizou duas coletâneas (Seleta, em 1974, para a editora José Olympio, e o mais recente Melhores Contos Bernardo Élis, em 2015, pela editora Global Pocket). Outra organização dos contos do autor foi realizada por José Geraldo Pires de Melo, por meio da série 10 contos escolhidos da editora brasiliense Horizonte, em 1985. Também, Rogério Max Canedo Silva (2016) cita o livro Contos esparsos, idealizado pelo próprio Bernardo Élis, mas não tivemos acesso à obra em questão.

${ }_{33}$ Estrofe extraída do poema "O ausente", inserido no livro Tradutor de chuvas (2011), de Mia Couto. 
compõem a nação moçambicana. Porém, permite um diálogo produtivo que inclui os signos da tradição africana deslocados no tempo, ou seja,

[...] rasurando-os, ficcionalizando os registros oficiais da história, a narrativa tece um "outro real", criando uma brecha para a volta do "já acontecido", mas para uma possibilidade em aberto daquilo que "poderia ter sido", assumindo a literatura um lugar de contradição e de crise dos discursos (FONSECA; CURY, 2008, p. 41).

De acordo com a figuração de uma memória ancestral, Ana Mafalda Leite (2013, p. 183) diz que a voz do autor faz com que haja uma coenunciação direcionada a: "um público geral (com a intenção de o fazer descobrir uma cultura) e um público moçambicano (a quem se devolve, recriadas, a Memória e a Voz) ${ }^{34}$. Por isso, a literatura de Mia Couto é muito propícia a uma análise da formação da sociedade moçambicana atravessada por facetas do arcaico e do moderno.

Sua linguagem é caracterizada como criação inventiva, inspirada no discurso de fonte popular que veio a dar base, junto ao escritor Ungulani $\mathrm{Ba} \mathrm{Ka}$ Khosa e ao poeta José Craveirinha, à formação nacional moçambicana através da literatura ${ }^{35}$. Por isso, com uma elocução única, apresenta os contornos de uma nação moderna e independente, por meio de uma escrita fundada no hibridismo da língua do colonizador e nas experiências linguísticas e culturais dos povos locais.

O movimento dos povos bantu do centro do continente africano, na busca por terras férteis, é característica fundamental da formação do homem moçambicano. Sua diversificação é encontrada também nos povos de distintas regiões que ali instalaram:

Ao norte da região do Zambeze instalam-se - para além dos Suaílis os Macuas, os Macondes e os Ajauas [...] já na parte sul do rio Zambeze impõe-se o grupo Chona (incluindo os Macarangas) com o imponente Império do Monomotapa; e, na parte norte-noroeste do mesmo Zambeze, o grupo Marave. Entretanto, na região sul, a par ainda dos Chonas e Angunes, encontramos os grupos Tsonga, Chope e Bitonga. Toda a imensidão de uma cultura expressa em várias subculturas. E bastariam alguns tabus em relação à Natureza para sugerir essa diversidade: desde as catástrofes devidas à

\footnotetext{
${ }^{34}$ Acredita-se que, apesar de Leite (2013, p. 183) falar em co-enunciação como "alegorias nacionais", na verdade, se trata de representações que dizem respeito à realidade objetiva, apesar do uso de sua liberdade poética. Assim, Lukács (1966, p. 11), num texto de 1934, define que a objetividade do mundo exterior possui autonomia em relação a sua consciência.

${ }^{35}$ Referimo-nos aqui ao estudo $A$ construção da imagem de moçambicanidade em José Craveirinha, Mia Couto e Ungulani Ba Ka Khosa (1998), de Gillberto Matusse, que explana melhor tais considerações.
} 
plantação de espécies estrangeiras como bananeiras ou laranjeiras, entre os Tsongas, até a proibição do consumo de peixe, entre os Angunes (CAVACAS, 2015, p. 33).

Ainda, a presença persa é evidenciada pela fundação das cidades de Sofala e Manica, destinadas à troca de preciosidades, como ouro e marfim. Banzaruto e Vilanculos são regiões que se destacaram pela colonização islâmica no século VII. Alguns povos se afirmaram com poder e dinastias, como aconteceu com os Zimbábue (1250-1450), os Maraves (por volta do século XIV) e os Monomotapas (metade do século XV). O Vale do Zambeze destacase pelas atividades políticas e econômicas, tendo força numa divisão social e numa política centralizada, o que antecipa a ideia europeia de estado que veio a se formar posteriormente.

O explorador português Pêro de Covilhã encontrou a região de Sofala em 1489, seguido de Vasco da Gama, que passara por Inhambane, Quelimane, Ilha de Moçambique, Mombaça e Melinde (CAVACAS, 2015, p. 3435). Se, de início, Moçambique era um porto seguro no caminho dos portugueses à Índia, desde que se assumiu enquanto centro comercial, sua interiorização ocorre no contato com os grandes chefes locais. A colônia revelou-se também uma grande fonte de minérios e especiarias, cujo centro de trocas era a região de Goa (CAVACAS, 2015, p. 35-37).

A autoridade portuguesa consolida-se com a instalação da administração na llha de Moçambique, mas seu poder não fora sentido enquanto dividira o reinado com a Espanha. Nesse período, holandeses, ingleses, franceses, alemães, austríacos e omanitas tentaram várias vezes conquistar o território (CAVACAS, 2015, p. 37-38). E ainda, a resistência de povos como os Monomotapa fez com que os portugueses desocupassem 0 Zimbábue em 1693.

Em contrapartida, os prazos $^{36}$ se mostravam mecanismos dos portugueses se apropriarem e administrarem a terra, assumindo as funções de chefes indígenas com o devido suporte político e militar do capital mercantil durante os séculos XVII e XIX (CAVACAS, 2015, p. 38). Por isso, Moçambique passou a ser também uma grande fonte de trabalho escravo para as atividades

\footnotetext{
${ }^{36}$ Um dos modos de assegurar a dominação portuguesa sobre a colônia moçambicana se deu pelo arrendamento de terras pertencentes a portugueses, o que foi chamado de prazos.
} 
econômicas no Brasil. Lourenço Marques fora fundada em 1782, e caracterizou-se pelas trocas de propriedades por marfim. A criação de um governo geral na colônia, no século XVIII, fez com que a referida cidade fosse dotada de uma estrutura governamental que estimulou a vida cultural na urbe. A dicotomia entre o palácio e a beira-mar estava consolidada:

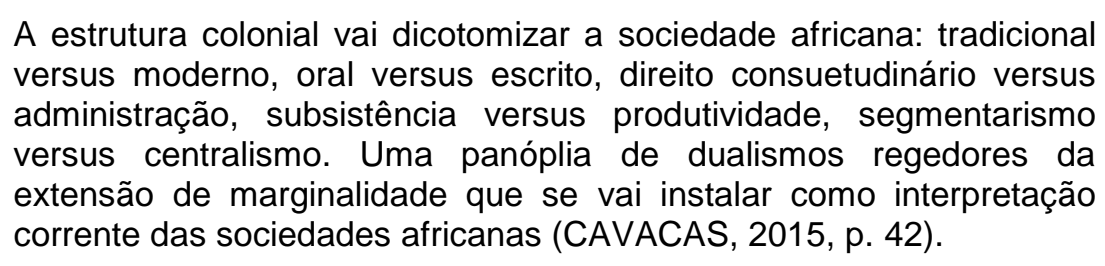

A criação de vários pequenos centros urbanos e letrados em Moçambique, à moda de Lourenço Marques, nas primeiras décadas do século $\mathrm{XX}$, reforçou uma modernidade cujo pioneirismo era atribuído à colonização, crença sustentada pelas elites brancas e locais (CABAÇO, 2009, p. 283-284). Nesses poucos centros urbanos, o estado português manteve as bases do aparelho estatal. Uma dessas bases era a imprensa.

Os jornais oficiais eram grandes promotores das atividades das elites brancas. Tendo suas atividades mais voltadas a Lourenço Marques, que "tornou-se lugar privilegiado dos confrontos políticos e sociais e o cadinho de novas formas de adaptação ao mundo moderno" (MAGAIA, 2010, p. 42), tais veículos de comunicação mobilizaram fortemente as pautas nacionais em um ambiente provinciano onde todos se conheciam.

Eduardo Mondlane, ao ter retornado da África do Sul, estimulou a criação de mais um grêmio, por exemplo, o Núcleo dos Estudantes Secundários de Moçambique (NESAM), cujo mérito é o de ser precursor do nacionalismo moçambicano proposto pela FRELIMO.

Além de integrador, o NESAM também valorizava o trabalho intelectual. Sua efervescência e influência na juventude promovia uma nação diferente da proposta pelo colonialismo português, cuja política era fundada no ódio entre as raças, uma preocupação que não era propriamente do cristianismo a serviço da máquina mercante (REGO apud MAGAIA, 2010, p. 48-49). O nacionalismo imperial português não fez senão produzir feridas, ao passo em que se julgava civilizador diante de povos que considerava bárbaros/selvagens. 
Essas tensões, definidas por Borges Coelho como "potencial de violência" em seu artigo "Da violência colonial ordenada à ordem pós-colonial violenta" (2003), são o motor dos conflitos internos de Moçambique até hoje, desde os embates entre a FRELIMO e o governo colonial português, que evoluíram ao conflito entre a FRELIMO e a RENAMO durante a guerra civil, até ao modo como as comunidades interioranas se organizam. Na verdade, esses conflitos foram potencializados com o uso de armas durante o processo colonial, não só letais mas também simbólico-culturais, uma prática do imperialismo português com o suporte dado pelo assimilacionismo. Daí se obtém um novo modelo de organização.

\begin{abstract}
Os aldeamentos surgem como verdadeiros espaços concentracionários de produção de violência. A aglomeração de pessoas em números até então inéditos implicou a quebra dos laços com a terra, desde sempre fonte estruturante da coesão comunitária e recurso base da sua reprodução material e cultural, da sua sobrevivência. Afectou gravemente as relações políticas e familiares cuja lógica sempre assentara no território; criou problemas de acesso a recursos, sobretudo de terra e água; estabeleceu terreno fértil para a irrupção de surtos de doenças (BORGES COELHO, 2003, p. 179).
\end{abstract}

Grupos de milícias foram criados para garantir a ordem interna, uma ação beligerante contra as forças nacionalistas. Por isso, não se pode dizer que a luta anti-colonial fora um processo unificado, uma vez que o acesso aos bens de consumo ficava cada vez mais restrito, inibindo a resistência. Desde o século XIX a interiorização só havia se dado pelos indianos, que foram grandes responsáveis pelo comércio interno em Moçambique (CABAÇO, 2009, p. 66). Ademais, o recrutamento de povos locais fazia com que o soldado africano, mesmo assimilado, já inserido em cultura, línguas e práticas sociais comuns àquelas populações, tivesse melhor domínio do local (p. 182). Esse empreendimento era mais barato à metrópole, mas ainda permanece recorrente a oposição ao negro selvagem e "terrorista", notadamente em contraste com o branco europeu, detentor de instrumentos pacificadores e civilizados.

A FRELIMO, por outro lado, tinha as suas vantagens:

Diferentemente de Portugal, que possuía um exército regular, a Frelimo contava com exército não convencional e desenvolvia táticas de guerrilha - atacava o inimigo e depois recuava, pois mantinha um santuário estratégico protegido na Tanzânia. A Frelimo contava ainda com um fator diferenciado, o tempo. Portugal precisava do sucesso imediato em sua ofensiva, ao passo que Frelimo se utilizava do 
conhecimento da região e da identidade com a população para fomentar ainda mais o sentimento de nacionalidade e, com isso, adensar o seu exército guerrilheiro. Dessa forma, o tempo contava a favor da guerrilha (VISENTINI, 2012, p. 92).

Se por um lado, o governo português veio a garantir a liberdade religiosa, por outro também assegurava a proteção à igreja católica (MAGAIA, 2010, p. 50), uma contradição que marca o processo de colonização lusitana em Moçambique. Durante a ditadura de Salazar, a Santa Sé portuguesa, em sua estrutura hierárquica, veio a apoiar fortemente a missão "civilizadora" nas colônias, enquanto que os enviados às missões surpreendiam por conceber "um Moçambique independente de acordo com os interesses culturais, religiosos e econômicos portugueses" (MONDLANE apud MAGAIA, 2010, p. 56). Hoje constatam-se intensas atividades de grupos religiosos estrangeiros no território de Moçambique.

A independência tardia, obtida no dia 25 de junho de 1975, um ano depois da Revolução dos Cravos, resulta da adoção de estratégias usuais de recrutamento local e militarização por parte do movimento nacionalista, diferente de Angola e Guné-Bissau (BORGES COELHO, 2003, p. 184-187). A partir daí, a FRELIMO e a RENAMO disputaram seus respectivos projetos nacionalistas, o que resultou na guerra civil moçambicana, cujo fim veio a acontecer em 1992. Na verdade, a RENAMO fora uma criação incentivada pela Rodésia, cujo acesso a mantimentos fora bloqueado por determinação da ONU. Ataques contra estradas e pontes de abastecimentos, sem falar da implantação de minas terrestres, foram suas principais ações contra a FRELIMO. Em 1990, após a morte do presidente Samora Machel, houve eleições diretas e abertura ao multipartidarismo, apesar da proeminência ainda evidente da FRELIMO sob os demais partidos. A guerra terminou em 1992, por meio de acordo de paz, mas a tensão entre a FRELIMO e a RENAMO ainda permanece.

Pautada na consciência nacional e na revolução,

[...] a ficção moçambicana tem até agora procurado na história colonial, ou pré-colonial, assunto para as estórias ou contos. É claro que estas estórias, bem como o processo de as escrever em prosa moderna, têm importância para o presente de Moçambique, apesar de versarem acerca do passado, ou acerca da interpretação do passado, à luz das circunstâncias presentes (CHABAL, 1994, p. 67). 
O caráter colonial, ou pós-colonial, da literatura moçambicana é alimentado por tensões acumuladas das sociedades coloniais mesmo em período pós-independência, marcas as quais o historiador e escritor moçambicano João Paulo Borges Coelho (2003, p. 176-177) diz serem responsáveis, por exemplo, devido a fatores internos e externos, pela aplicação do socialismo em Moçambique, do caráter totalitário do Estado e da fragmentação das identidades. Um fator atribuído aos países ocidentais e desenvolvidos, entretanto, é o da "[...] acentuação e generização progressivas e constantes da pobreza" (BORGES COELHO, 2003, p. 177), que cria atrativos à elite moçambicana que vende o resto de seu país, mas dissimula-se na condição de grupo dirigente nacionalista de primeira hora (COUTO, 2005, p. 25). Essas assimetrias foram percebidas e figuradas pela contística de Mia Couto.

O autor moçambicano diz em entrevista ao pesquisador Patrick Chabal (1994, p.276) que sua mudança da cidade da Beira para Lourenço Marques, atual Maputo, em 1971, foi um grande choque, uma vez que na Beira sua família sempre morava em zonas periféricas, perto de negros. No novo logradouro, cuja situação espelhava um grande apartheid, havia uma enorme separação entre negros e brancos. Na verdade, essa atmosfera se processava desde a primeira década do século $\mathrm{XX}$, o que resultou, a final da segunda, na criação de diversos grêmios, cuja diversificação intensa se dava por etnias, segundo constata o moçambicano Magaia (2010, p.42-43). Até hoje Maputo tem suas ruas habitadas predominantemente por negros, sendo que certa elite branca se resguarda em lugares mais isolados e protegidos.

Mia Couto se dedicou ao jornalismo, desistindo inclusive do curso de Medicina para tal. É importante ressaltar a relevância do periodismo para o movimento de libertação e consolidação nacional que estava se firmando antes e depois do processo de independência. Não bastando a influência do pai poeta e da mãe contadora de estórias, diz Fernanda Cavacas (2015) que o trabalho de Mia Couto na imprensa teve importância significativa para a gestação do autor:

Analisando todos estes órgãos de informação não reconheceremos marcas particulares do escritor: trata-se de um trabalho comunitário com objectivos nacionalistas militantes bem definidos, onde não cabe 
a subectividade ou outros ideais que dêem corpo a manifestações artísticas de índole individual. Começam, no entanto, a aparecer exepções a esta militância unificadora e é no próprio jornal que as crônicas de Mia Couto surgem como brechas criadoras de diferença ao nível linguístico, temático e mesmo conceptual. E o público moçambicano sente-se compelido a participar nas reflexões que the são propostas, de tal forma que não raro esgotam a tiragem do jornal (p. 110).

Assim, seu primeiro livro, Raiz de Orvalho, publicado em 1983, era composto de poemas que contestavam a hegemonia literária da poesia militante.

A decisão de Couto de regressar à universidade o levou a cursar Biologia, área na qual teve a oportunidade de visitar várias comunidades rurais, possibilitando maior contato com o povo interiorano de sua nação. Seu interesse pelas culturas e histórias que ouvira ou encontrara fez surgir, em junho de 1986, o seu primeiro livro de contos, Vozes anoitecidas (CAVACAS, 2015, p. 112). Os contos apresentam um sentido trágico que remete não só aos males da guerra civil em curso, mas também ao confronto entre o mundo urbano tradicional e os valores místicos e míticos da cultura rural (LEITE, 2012, p. 41). As palavras do poeta José Craveirinha, ao prefaciar a obra em sua edição portuguesa, adequam-no bem à tradição dos contos orais moçambicanos:

\begin{abstract}
Obtendo sugestivos efeitos significantes, Mia Couto maneja a linguagem das suas figuras legitimando a transgressão lexical de uma fala estrangeira com o direito que lhe permite o seu papel de parente vivo de Vozes anoitecidas. E, tal como João Dias e Luís Bernardo Honwana já a isso, óbvia e necessariamente, haviam recorrido, também Mia Couto consegue na escrita refletir vivências e particularismos sem descer ao exotismo gratuito, ao folclorismo cabotino. Igualmente sem se estatelar no linguajar chocarreiro de baixo nível, sem cair na chacota ou no indigenismo de burlesca ironia do sendo de humor pró-colonial (CRAVEIRINHA, 2013, p. 8).
\end{abstract}

A decisão de um idoso de abrir antecipadamente uma cova para a sua esposa ainda viva, e um sobressalto para o destino do velho morrer ao final, como trata o conto "A fogueira", "[...] é a ironia dramática levada ao limite do absurdo" (NOA, 2013, p. 99) num mundo virado ao avesso, uma espécie de satirização das crenças aprisionantes. Mia Couto afirma em entrevista que se trata do conto que ele mais gostou de escrever. "Por me surgiu de um jacto, e não tive que corrigir ou modificar uma única linha. Foi a única vez que isso 
sucedeu"37. Desses acontecimentos ordinários que se pode perceber a falta de condições propícias à vida hodierna. Outro conto que melhor descreve 0 período da guerra civil é "O dia em que explodiu Mabata-bata": uma mina explodida por um boi que tinha sido destinado ao lobolo fez com que o evento fosse interpretado como um raio divino desfechado por Azarias, um pequeno pastor, e sua família, o que mostra "[...] o rastro do sobrenatural na natureza" (LEITE, 2012, p. 45) de forma a contestar os fatos científicos a partir da ira divina.

O livro Cronicando, publicado em 1988, foi resultado da reunião de crônicas e $\operatorname{contos}^{38}$ publicados em jornais de Moçambique e Portugal.

[...] fizeram a divulgação de hábitos e costumes, sonhos e vivências, do homem moçambicano. E o escritor ultrapassa largamente a crônica jornalística utilizando recursos literários na recriação do real de que parte na busca da estória poeticamente sentida e contada à maneira de um griot africano (CAVACAS, 2015, p.114-115).

A duplicidade entre o real e o irreal, ao humor típico de um Guy de Maupassant, são característicos dessa obra, e talvez o que tenha inspirado vários pesquisadores a investigarem tal conformação dialética no livro de Couto, inclusive nos seus romances. O conto "Sangue da avó, manchando a alcatifa" trata da estranheza da avó, que viaja do interior para a cidade por motivos de guerra, em relação à realidade urbana consumista e informacional. Ao final do conto, a avó retorna para a sua terra e é alcunhada de louca por seus parentes. Essa loucura, entretanto, revela a distância que a modernidade das cidades, da indústria cultural e do consumo tomou em comparação à vida rural, mítica, coletiva e de subsistência.

Em 1990, Couto publicou o seu Cada homem é uma raça. Constituído por onze contos, o livro é, conforme o próprio autor atesta em sua intervenção intitulada "Uma cidadania à procura da sua cidade" (2004), manifestação do seu pensamento de que os medos e angústias particulares são uma forma de

\footnotetext{
${ }^{37}$ A referida entrevista, realizada por nós, se encontra no Anexo I deste trabalho, na página 166.

${ }^{38}$ É importante não deixar de ressaltar que o caráter formal de Cronicando é passível de discussão, sendo que os aspectos estruturais e os conflitos (LARANJEIRA, 2001, p. 194) são comuns tanto em contos como em crônicas do autor. Mia, particularmente, as caracteriza como "estórias", uma definição que acentua a relação de suas obras literárias com a história (XAVIER, 2010, p. 142). O caráter cotidiano da crônica é importante para a ficção de Mia Couto como um todo, como foi demonstrado. Apesar dessa indagação ser ilustrativa nesta apresentação breve da contística de Mia Couto, não se pretende levá-la adiante neste trabalho.
} 
nacionalidade individual em busca de civilidade na convivência com o outro ${ }^{39}$. Ainda, diz que

Quando se diz que cada homem é uma raça é no sentido de consolidar aquilo que é a nossa semelhança como humanos, a nossa própria humanidade. O texto que dá título ao livro conta a história de João Passarinheiro, que responde ao polícia que lhe pergunta qual a sua raça e ele diz: a minha raça sou eu mesmo, cada homem é uma raça. O sentido desta resposta encerra algo mais fundo, que é o conceito de que cada pessoa é uma humanidade individual. Somos particulares mas partilhamos aquilo que é essencial, na maneira como sofremos, como pensamos, como sentimos (COUTO, 2016, p. 13).

João Passarinheiro é personagem do conto "O embondeiro que sonhava pássaros". Incompreendido por encantar pássaros, o que impressionava as crianças, João fora perseguido pela população branca local, que o tratava de maneira preconceituosa. "Em verdade, seu astro não era o Sol. Nem seu país era a vida. Talvez por isso que ele habitasse com a cautela de um estranho" (COUTO, 2013, p. 63). A perseguição, entretanto, resultou na morte de uma das crianças, um final trágico para a mágica que ele invocava. A humanidade de João, incompreendida por questões de raça e falta de compreensão para com o outro, é similar à estrutura de "O apocalipse privado do tio Gueguê". A existência plena, dependente do uno e do diverso, não é percebida numa lógica de guerra que deriva da herança maniqueísta do colonialismo. Foi o que o personagem principal aprendera com seu tio Gueguê, que fora morto pelo sobrinho pela mesma razão. "Ao fim, eu disparava contra todo aquele tempo, matando esse ventre onde, em nós, renascem as falecidas sombras deste velho mundo" (COUTO, 2013, p. 46), uma sombra do potencial de violência presente por gerações. Com paratextos que transitam entre os contos, o livro diz respeito, sobretudo, à formação nacional de Moçambique, antes e depois de sua independência, figurando nos personagens seu pleno processo de transformação e autoconhecimento (MOREIRA, 2013, p. 283-299).

A perspectiva de futuro foi uma novidade nos contos de Mia Couto, a partir de Estórias Abensonhadas (1994), as quais recuperam os sentidos míticos e mágicos relacionados ao homem e à realidade moçambicanos. Afinal, a publicação ocorre pouco tempo depois de assinado o acordo de paz entre a

${ }^{39}$ Couto verifica no referido texto uma carência de entendimento a partir de particularidades entre os indivíduos e povos de Moçambique. Ainda, destaca que o progresso comum de seu povo deve ser entendido por meio dos elementos particulares destacados. 
FRELIMO e a RENAMO, "[...] marcando-se tanto pela esperança na reconstrução do país como pela necessidade de lidar com a memória traumática dessa guerra" (MORAES, 2013, p. 195). Prova disso é o conto "Chuva: a abensonhada", que figura o diálogo do narrador-personagem com a Tia Tristereza, que percebe a precipitação como fenômeno anunciador de novos tempos para um Moçambique acostumado e cansado do período da guerra e da seca:

[...] A senhora idosa não tem dúvida: a chuva está a acontecer devido das rezas, cerimónias oferecidas aos antepassados. Em todo o Moçambique a guerra está parar. Sim, agora já as chuvas podem recomeçar. Todos estes anos os deuses nos castigam com a seca; Os mortos, mesmo os mais veteranos, já se ressequiam lá nas profundezas (COUTO, 2012, p. 44).

As possibilidades são reveladoras, a ponto de se conceber uma outra história para o homem moçambicano, com subsídios que tenham mais a ver com a sua realidade. Em "O cachimbo de Felizbento", por exemplo, o personagem-título recusa-se a desocupar seu local, a mando dos delegados da capital, uma vez que lá estava enraizado. Ele então decide se enterrar junto a seu cachimbo, do qual brotara e crescera uma árvore frondosa, cuja fumaça era sinal de que Felizbento ainda fumava seu cachimbo, à procura da verdadeira paz. Como é colocado ao início do conto,

Toda a estória se quer fingir verdade. Mas a palavra é um fumo, leve de mais para se prender na vigente realidade. Toda a verdade aspira ser estória. Os factos sonham ser palavra, perfumes fugindo do mundo. Se verá neste caso que só na mentira do encantamento a verdade se casa à estória. O que aqui vou relatar se passou em terra sossegada, dessa que recebe mais domingos que dias de semana (COUTO, 2012, p. 47).

Mesmo com esses elementos comuns e a esperança de reconstrução do país, o sonho pode se mostrar em contradição ao ideal de país a se construir após a sucessão de guerras, como o pedido de desocupação por parte de Felizbento.

Os Contos do nascer da Terra (1999) permanecem numa linha similar, contendo 35 contos publicados em jornais e revistas durante os anos de $1996 \mathrm{e}$ 1997. Os relatos figuram as contradições de Moçambique, focalizando seu cotidiano com livre imaginação (DAVID, 2013, p. 203). "A casa marinha”, por exemplo, trata da convivência do narrador-personagem com o velho Tiane Kumadzi, que estava construindo um barco com estranhos gravetos. O barco 
foi notado pela população local, que considerava Tiane louco por construir coisas inexistentes, como a ideia de futuro. Um adivinho percebeu o barco como uma ameaça, e logo todos quiseram queimá-lo. Porém, o barco permaneceu intacto, e Tiane se fundiu a ele, evidenciando que o mar deseja reunir as pessoas (COUTO, 2014, p. 147).

O caráter coletivo é evidenciado pelo exercício criativo em consonância com os elementos naturais. Outro tema chamativo no livro é a morte, o que levou o moribundo e asilado Senhor Fernandes de "Falas do velho tuga", acometido por febre, a ser curado em um ritual africano. Em sua nova vida, o personagem anseia por novas relações, o que também reflete uma outra visão em relação ao país.

Na berma de nenhuma estrada e outros contos (2003) contém 38 contos, que dizem respeito às relações sociais num espaço determinado. $O$ conto título da obra trata de uma protagonista chamada de "menina", que costuma ficar à beira da estrada à espera de carona. Criada pelo tio, ela se revela desejosa de sair de seu povoado para outro lugar. Sua travessia, que a afasta de sua origem, a faz perceber que "menina" é a sua identidade diante do mundo mesmo, ao seguir para um destino incerto. "Rosita", por seu turno, apresenta um menino resgatado de uma enchente torrencial pela força tarefa da África do Sul. No helicóptero, pede para resgatar seu boi, Makalatani, que estava consigo, mas os oficiais dizem que ele estava sozinho. Lá no alto, o protagonista encontra sua vizinha, Sofia Pedro, que havia dado à luz em cima de uma árvore e fora resgatada. As fronteiras entre os indivíduos em um mundo globalizado dão a ver as diversas facetas que Moçambique ostenta, principalmente no que tange a aspectos atinentes à ancestralidade e aos destinos individuais e coletivos.

O último livro de contos de Mia Couto até então $0^{40}$, $O$ fio das missangas (2004), consolida o foco no espaço, em detrimento do tempo, para acentuar o caráter fragmentário da vida social. O cruzamento de tais categorias narrativas, desse modo, concretiza a possibilidade de uma divisão temática maior e mais incisiva, com direito ao uso de introspecção psicológica para melhor

40 Convém citar o livro de contos A menina sem palavra - histórias de Mia Couto (2013), publicado pela editora Companhia das Letras na série Boa Companhia. Neste estão organizados vários contos do autor moçambicano, em diferentes fases de sua carreira. 
caracterizar seus personagens. Couto, no entanto, anuncia ao início do livro: "A missanga, todos a vêem. Ninguém nota o fio que, em colar vistoso, vai compondo as missangas. Também é assim a voz do poeta: um fio de silêncio costurando o tempo" (2009, p. 5).

Por isso, apesar de evidenciar o caráter fragmentário do conto moçambicano contemporâneo, o propósito de Mia Couto é o de "[...] investir em formas de totalização" (CHAVES, 2013, p. 242). Destarte, a história ainda é uma chama cada vez mais acesa em sua obra, independentemente de não ter mais se dedicado ao conto tão assiduamente como ao romance.

$\mathrm{O}$ conto que nomeia o último livro referido trata dos casos de JMC com várias mulheres, registrados como missangas que comporiam o colar. Porém, devido à morte da mãe, ele não mais as encontrou. Incapaz de se lembrar de coisas recentes, só se recorda das ocorrências antigas, tal como a relação com a mãe, cuja morte o abalara profundamente. Destaca-se a história pessoal de JMC e sua mãe, essencialmente distinta das outras mulheres, por dar-lhe origem e possuir caráter familiar, o que também faz separar as relações tradicionais/ancestrais das relações modernas/inautênticas. Já "O rio das Quatro Luzes" fala sobre a mentira de um avô em relação ao seu neto, dizendo que prometera a Deus que trocaria de vida com o menino. Este era desejoso por envelhecer e morrer logo, daí o ancião preocupou-se em ensinar-lhe todos os mistérios da infância. $O$ narrador não tem a preocupação de ser poeticamente exuberante no livro (ROSÁRIO, 2013, p. 223), o que torna os personagens em verdadeiros motores narrativos e propicia uma melhor organização temática (ROSÁRIO, 2013, p. 227).

Os contos de Mia Couto dão a ver o compromisso do escritor com o seu país, sua realidade e sua história conflitantes, sem deixar de acentuar os problemas contemporâneos, transformando-os em matéria estética. $O$ empenho de sua obra é reconhecido, demonstrando evidente relevo realista da figuração narrativa.

A seleção de contos deste trabalho procura dar proeminência ao projeto estético-ideológico dos dois autores em questão, cujos compromissos com suas diferentes realidades histórico-sociais e modos de narrar colocam em destaque quatro movimentos dialéticos que mobilizam nossa discussão nos 
próximos dois capítulos da dissertação. Com relação ao campo e à cidade, elegeu-se "Rosa", de Bernardo Élis, e "A avó, a cidade e o semáforo", de Mia Couto. Para se referir a litoral e sertão escolhemos "Ontem, como hoje, como amanhã, como depois" e "O poente da bandeira". Mito e religiosidade têm como objetos de análise os contos "Virgem santíssima do quarto de Joana" e "A velha engolida pela pedra". Por fim, razão e loucura são perscrutadas nos contos "Pai Norato" e "Rosa Caramela". 


\section{3. "Daqui dois homens atiraram-se lá embaixo: um morreu - orai por ele, o outro pede esmola"41: a notação espacial no conto}

$\mathrm{Na}$ aldeia era simples: todos dormiam despidos, enrolados numa capulana ou numa manta conforme os climas. Mas lá, na cidade, o dormente vai para o sono todo vestido. E isso minha avó achava de mais. Não é nus que somos vulneráveis. Vestidos é que somos visitados pelas valoyi e ficamos à disposição dos seus intentos. Foi quando ela pediu. Eu que levasse uma moça da aldeia para me arrumar os preceitos de viver.

COUTO, Mia. "A avó, a cidade e o semáforo". In: O fio das missangas. São Paulo: Companhia das Letras, 2009. p. 126-127.

${ }^{41}$ Versos extraídos do poema "Partida automática", da coletânea de poemas Primeira chuva (1971), de Bernardo Élis. 
A dialética campo e cidade trata da relação do homem com a terra, o desenvolvimento cultural e econômico da sociedade, as transformações sociais que afetam a "vivência das comunidades humanas" (WILLIAMS, 2011, p. 11). Já a dialética litoral e sertão diz respeito à disposição geográfica, política e econômica, que também revelam tensões de caráter histórico. Em relação à primeira problemática, analisar-se-ão os contos "Rosa" (1966), de Bernardo Élis, e "A avó, a cidade e o semáforo" (2004), de Mia Couto. Quanto à segunda, examinar-se-ão os contos "Ontem, como hoje, como amanhã, como depois" (1965), de Bernardo Élis, e "O poente da bandeira" (1994), de Mia Couto.

\section{1. "Dos caprinos aprenderam: em qualquer nada, inventam os mais vastos pastos" ${ }^{42}$ : a dialética campo e cidade}

As relações que envolvem a dialética campo e cidade dizem respeito a uma perspectiva histórica, de caráter subjetivo que não quer dizer necessariamente veracidade histórica (WILLIAMS, 2011, p. 25). Raymond Williams (2011) afirma ser possível conhecer a verdade dos fatos, tendo em conta os vestígios encontrados. Hoje se sabe que

[...] O campo passou a ser associado a uma forma natural de vida da paz, inocência e virtudes simples. À cidade associou-se a ideia de centro de realizações - de saber, comunicações, luz. Também constelaram-se poderosas associações negativas: a cidade como lugar de barulho, mundanidade e ambição; o campo como lugar de atraso, ignorância e limitação. O contraste entre campo e cidade, enquanto formas de vida fundamentais, remonta à Antiguidade clássica (WILLIAMS, 2011, p. 11).

Mesmo com diversas formas de organização e práticas sociais, essa relação trata da posição do homem em relação à terra, algo que não se dá ao mero acaso. Nesse aspecto, Lukács (2010, p. 151-152) discorre sobre a dicotomia de origem marxista casualidade e necessidade ${ }^{43}$. Ou seja, a categoria trabalho é essencial para considerar tais relações, algo que remonta

\footnotetext{
${ }^{42}$ Estrofe extraída do "Poema da Cabra", da coletânea de poemas Tradutor de chuvas (2011), de Mia Couto.

${ }^{43}$ A análise proposta por Lukács em seu texto "Narrar ou descrever" diz respeito a um evento de uma corrida de cavalos nas obras Nana, de Zola, e Ana Karenina, de Tolstói. A totalidade da obra confere a necessidade ou a casualidade da cena em relação ao todo da obra, sendo que a causalidade se reflete estruturalmente na obra e define a técnica individual de cada autor. Não se trata somente de um discurso individual, mas da formação de cada artista, que é refletida em sua escrita e na estrutura da obra. Ainda, reflexo do movimento da história em planos coletivo e individual.
} 
aos tempos dionisíacos (WILLIAMS, 2011, p. 61) e a mudança de sua configuração na Idade Média e, ainda, a sua expansão no tocante aos padrões exigidos pelo capitalismo internacional. As estações e os eventos da natureza relacionados à colheita e ao plantio são aspectos que realçam a associação do homem com a terra (WILLIAMS, 2011, p. 57-58), acentuando uma maior conexão e domínio relativamente aos meios de produção.

O campo, geralmente associado à acumulação, tem profunda relação com os princípios do capitalismo ${ }^{44}$, tal como Karl Marx postula em Manuscritos econômico-filosóficos (1844). O salário do trabalhador é necessário somente à subsistência, ou a uma sobrevida animal. Já a posse dos meios de produção é tida como eficiente estratégia de acúmulo (MARX, 2010, p. 23-24), e não como como modo de realização social. O capital acaba por se transformar em poder de compra e governo, um alicerce positivista de direito de posse e controle (MARX, 2010, p. 39-40). O capital primitivo, de natureza unilateral ou multilateral, pode apresentar forte concentração e acumulação, tanto de uma maneira quanto de outra. Essa liberdade tem muito a ver com o desenvolvimento dos modos de organização humana. Considerando a concorrência como o triunfo do capitalismo, esta tem o poder de atuar "beneficamente sobre a elevação do salário, assim como sobre o barateamento das mercadorias em favor do público consumidor" (MARX, 2010, p. 48). Assim, sendo o valor da renda da terra essencial aos salários, à subsistência e, sobretudo, ao acúmulo, o arrendatário tem o poder de produção na cultura e na melhoria da terra, de modo que explora vantagens na sociedade pelo aumento da população e pela melhoria dos meios de comunicação (MARX, 2010, p. 6768). Em níveis de economia nacional, o monopólio e a posse de meios naturais dependem das qualidades do solo, o que pode alterar importantes variáveis da renda e do valor da terra (MARX, 2010, p. 63-64). Assim como há o processo de alienação da propriedade de terra ao latifundiário, ocorre também o mesmo com o trabalho em relação ao produto.

A mistificação do campo ocorria no intuito de disfarçar a tensão entre o trabalhador e o latifundiário, trazendo à tona o valor bucólico. Na verdade,

\footnotetext{
${ }^{44}$ Isso porque a propriedade fundiária alienada é a raiz da propriedade privada, o que também diz respeito à relação entre o proprietário e o trabalhador reduzida a uma lógica nacionaleconômica de explorador e explorado (MARX, 2010, p. 75).
} 
[...] Não apenas o trabalho, mas até mesmo os diferentes produtos das estações - tudo é negado ou obscurecido pela mistificação elogiosa: abundância inata, "delícias naturais". Chamar isso de ordem natural é uma deturpação da linguagem. (...) não são descrições da vida rural, e sim elogios sociais, as hipérboles tão familiares da aristocracia e seus agregados (WILLIAMS, 2011, p. 62).

Williams (2011) revela que o determinismo do capital, ao logo da história da literatura inglesa, está intimamente relacionado ao impedimento de comparações reais e à promoção de cotejamentos superficiais que não dão a ver "a sordidez das relações decisivas que regiam a vida das pessoas" (WILLIAMS, 2011, p. 94). Com a Revolução Industrial, Williams analisa os diferentes graus de bucolismo, e conclui que a praticidade do trabalho desconsidera a oposição entre verdade e poesia, caracterizando o bucolismo como um anti-realismo impeditivo à totalidade das relações sociais entre a cidade e o campo. As relações daqueles que possuem maior acesso à cidade também se refletem social e esteticamente nos indivíduos, detentores da racional cidadania consumidora e do trabalho livre (MARX, 2010, p. 94). Isso distancia o homem da natureza, enquanto verdade, e problematiza tais relações, que passam a não serem vistas processualmente ${ }^{45}$, apesar do esforço exigido pela mistificação inerente ao trabalho poético (WILLIAMS, 2011, p. 59).

A colonização, pela configuração de estado, fez com que o desenvolvimento dos meios de produção, em seu modelo industrial, associado às etapas de desenvolvimento (WILLIAMS, 2011, p. 456), tornasse possível a dependência entre nações, o que altera a forma estética com que são registradas as tensões entre campo e cidade. Na verdade,

O capitalismo, enquanto modo de produção, é o processo básico por trás da maior parte da história do campo e da cidade que conhecemos. Ao longo de séculos, seus impulsos econômicos abstratos, suas prioridades fundamentais no campo das relações sociais, seus critérios de crescimento, lucro e prejuízo vêm alterando nosso campo e criando os tipos de cidades que conhecemos. Em suas manifestações finais, sob a forma de imperialismo, ele alterou 0 mundo (WILLIAMS, 2011, p. 491).

Seus efeitos, na totalidade, são sentidos de forma concomitante, em diferentes graus, o que realça a sobreposição de um em relação ao outro. Até

${ }^{45}$ Refere-se aqui à indistinção entre trabalho e salário, provocada pela liberdade (relativa) de uso do salário por parte do trabalho, um fenômeno possível pela reformulação da vida na cidade com o advento da indústria (MARX, 2010, p. 94). 
mesmo na cidade, a produção de mais-valia, por parte do sistema capitalista, faz da urbanização um processo que absorve

[...] o excedente de produção que nunca deixa de produzir. Dessa maneira, surge uma ligação íntima entre o desenvolvimento do capitalismo e a urbanização. Não surpreende, portanto, que as curvas logísticas do aumento da produção capitalista sejam, com o tempo, muito semelhantes às curvas logísticas da urbanização da população mundial (HARVEY, 2014, p. 30).

Trata-se de uma esfera que faz com que os impactos econômicos sejam imprevisíveis, em razão do desenvolvimento geográfico desigual de nações e regiões. Esses nichos transformaram as comunidades em mercadorias, consumidas como um

[...] modelo de socialização da sociedade humana. Seu impacto vem aumentando $o$ individualismo isolacionista, a ansiedade e a neurose em meio a uma das maiores realizações sociais (pelo menos a julgar por sua gigantesca escala e pelo fato de ser onipresente) já criadas na história humana para a concretização de nossos mais profundos desejos. (HARVEY, 2014, p. 47)

A fragmentação das cidades e das relações tornou possível a prerrogativa de que "o modo como vemos o mundo e definimos possibilidades depende do lado da pista em que nos encontramos e a que tipo de consumismo temos acesso" (HARVEY, 2014, p. 47). Tal reestruturação possui consequências que atingem não só a arte, como também os marginalizados, em razão do processo de transformações aceleradas (HARVEY, 2014, p. 4950). Ressalta-se, portanto, o momento de escolha por parte do artista e de seu tempo, da casualidade à necessidade.

O tipo de colonização implantada, no caso brasileiro, fez com que a grande propriedade monocultural fosse propícia à produção "de certos gêneros de grande valor comercial e por isso altamente lucrativos" (PRADO JR., 2011, p. 126). Sendo uma unidade ligada a um sistema típico internacional, a monocultura também era atrelada ao trabalho escravo, o que estruturou a grande propriedade rural como base econômica e social brasileira destinada à exploração. Essa estrutura foi modelo para a extração de minérios e à pecuária, que também preservou a concentração de riqueza dos latifundiários e manteve o trabalhador em condição degradada de existência. O crescimento da população fomentou a criação de um mercado interno, apesar de preocupado mais quantitativamente do que qualitativamente (PRADO JR., 
2011, p. 130). A economia de exploração ainda se manteve presente até depois da independência, o que nos faz pensar nas novas demandas do mercado, mas poucas mudanças estruturais na ordem social e econômica do país.

No caso moçambicano, por sua vez, a sociedade comunitária tribal passou por um processo de dissolução democrática, propício "ao nascimento de relações feudais e de sistemas hereditários tribais e monárquicos" (NKRUMAH, 2010, p. 31) A introdução da monocultura acarretou o abandono do espírito coletivo das comunidades africanas em prol do aparecimento da propriedade e das pequenas produções, uma vez que, no imperialismo a economia colonial se vincula ao mercado mundial. Os títulos de terras eram outorgados aos chefes tribais e, caso algumas possessões não tivessem qualquer vínculo, seriam cedidas à coroa portuguesa. A divisão social entre os latifundiários africanos e portugueses também era muito ostensiva. A dependência ao capital estrangeiro fez nascer uma pequena burguesia e, em seguida, sua vertente urbana. $O$ sul do território teve a urgência de um projeto modernizador da capital, com direito a um novo aparelho estatal (CABAÇO, 2009 , p. 70). A liberdade da manutenção de características propícias à exploração desenfreada, realizadas conforme os interesses do mercado internacional (NKRUMAH, 2010, p. 33), ocorreu a partir da impossibilidade de Portugal de investir na colônia, que se viu aberta ao mercado exterior. A luta pela independência seguiu o mesmo caminho em décadas recentes. Tendo como alvo o imperialismo colonial, esqueceram-se dos ideais ocidentais da burguesia moçambicana, como o assimilacionismo. As inúmeras privatizações das empresas nacionais são acompanhadas de oitenta por cento da população empregada na agricultura de subsistência de pequena escala, sendo que a falta de exploração de seus noventa por cento de terras cultiváveis são um ponto importante a ser contrastado com a grande importação de bens de consumo.

No tocante à obra de Bernardo Élis e Mia Couto, estamos diante de escritores que optam preferencialmente pelo espaço rural, pois são originários de países de forte tradição campesina. Couto $(2005$, p. 94) registra o alto grau de crescimento urbano no seu país e já atribui à cidade um estatuto de 
modernidade. "Mas aqui surge um problema - quanto é que as nossas cidades são já urbanas, no sentido da cultura e do modo de viver em civismo"? A resposta a esse processo, de acordo com o autor moçambicano, dá-se pela alteridade. Élis (1983, p. 12), por seu turno, diz que as populações rurais migraram para as cidades, o que ainda faz da cultura tradicional o seu referencial, mesmo com o grande consumo no campo de mercadorias oriundas da moderna cidade. É nessa conjuntura histórica que surge o conto "Rosa".

"Rosa", publicado por Bernardo Élis em 1966, trata da chegada de uma mulher rústica, vinda do sertão, para a cidade. Ela se torna empregada na casa de uma família, mas não compreende a cidade por seus costumes e práticas. Por isso, ao final do conto, Rosa foge de lá. Alguns destaques em relação a esse conto são o preparo grosseiro dos alimentos e a conexão entre homem e a natureza. Por isso, "Rosa" é, por excelência, um conto sobre campo e cidade.

Em se tratando da relação entre homem e natureza, é importante considerar a cultura como meio de apropriação de recursos que supram as necessidades primárias e, em seguida, estejam em conformidade com as mudanças sociais atinentes à dinâmica entre os grupos (CANDIDO, 2010, p. 24-25). Uma dessas necessidades primárias ${ }^{46}$ é a alimentação, cujo primeiro estágio é caracterizado pela subsistência. Por isso, o conto começa pela especificação de hora e ambiente:

Foi numa hora de almoço. O dia, era um dia claro, de muito sol, as andorinhas voavam no beiral. Na porta da rua ouviu-se um ruído. Um saco de roupa jogado no chão? Em seguida um gemido como se alguém velho ou muito cansado se assentasse (ÉLIS, p. 75).

É revelado um receio da família por meio do ato de fechar a loja na hora do almoço ou do jantar:

\footnotetext{
As refeições eram tomadas quase às escondidas, fechadas as portas e as janelas que davam para a rua, como se comer fosse ato proibido ou indecente. Existiam roceiros e vagabundos que farejavam de longe a comida, entravam pela casa dentro e submetiam ao Reimundo ao dilema: ou me dão de-comer ou não me dão de-comer.

Se seu Reimundo desse o de-comer, teria que suportar a despesa, teria que arcar com o risco de se contaminar com as
}

${ }^{46}$ Entende-se como necessidades primárias as que são vitais. Chamá-las de primárias é nosso modo de estabelecer conexão com entre o nível biológico e assim sucessivamente, propiciando o acúmulo o qual faz com que a cultura em nível social realize a transformação necessária. É claro que isso, como coloca Marx (2010, p. 70), isso não significa que essa transformação seja automática. 
doenças que esses filantes geralmente traziam, repelentes e transmissíveis.. E teria que passar vexames, o hóspede sempre sairia falando da pobreza da mesa, da pobreza dos pratos e talheres.

Se não desse comida, arcaria com a malediscência do povo, com o comentário de cauíra ou ridiqueza, e até perderia algum possível freguês.

$O$ remédio era amoitar-se. Se alguém batia, como naquele momento, Reimundo não se movia. Deixava que o sujeito cansasse de sentar os nós dos dedos na madeira dura e croquenta da porta e se fosse embora. Ou que esperasse.

No trivial, quando alguém batia, tomava a refeição ainda mais devagar. O filho é que na sua inocência dava o cavaco, engolia depressa o feijão e se dispunha a ir atender (ÉLIS, 2006, p. 76).

Desta vez o menino não se conteve e foi atender a porta. O pai, tentando voltar a sua narrativa, fora criticado pelo filho:

[...] que o pai tinha uma maneira terrivelmente meticulosa de narrar. Casos certos demais, muito plausíveis. Sua voz também era sempre titubeante, numa angustiosa busca do vocábulo mais anódino, aquele que traduzisse a ideia de modo mais vago e incapaz de ferir a susceptibilidade de quem quer que fosse. (ÉLIS, 2006, p. 76-77)

$O$ menino imaginou ser alguém ferido, um homem esfaqueado. $O$ pai retrucou: "Se fosse ferido então viria para a nossa porta? la para a farmácia, para a porta do delegado. Não é nada. Acabe o almoço, ora!" (ÉLIS, 2006, p. 78),, mas abriram a porta e encontraram uma mulher em busca de onde dormir e que não morresse de fome, oferecendo também os seus serviços. Rosa, diz: "Sô chegante, sá dona, num conheço ninguém no comerço..." (ÉLIS, 2006, p. 78), explicando que ficara órfã de pai e "que morava longe toda a vida, num lugar que tinha serras altas luminosas, com um rio escuro e gemedor" (ÉLIS, 2006, p. 78).

Rosa fora contratada, mas seus serviços atinentes ao cozimento e preparo de alimentos foram recusados:

[...] E Rosa se foi ficando para lavar uma roupa, rachar lenha, pilar arroz, socar paçoca, capinar quintal, torrar e socar café, fazer sabão, buscar água na bica. Cozinhar ela bem que principiou, mas dona Rita desistiu.

Não havia ninguém que aguentasse engolir seu feijão dessorado, seu arroz grudado na panela, sua mandioca cozida com casaca e tudo, suas carnes mal refogadas, geralmente destemperadas, pois onde ela nasceu e se criou o sal era muito vasqueiro e carecia de estar não gastando sempre. (ÉLIS, 2006, p. 78)

A rusticidade com que preparava os alimentos distancia o ambiente do qual Rosa provinha e a cidade/povoado em que se encontrava. Na verdade, 
trata-se do acesso a diferentes recursos, técnicas e necessidades de alimentação.

Mais tarde, ao receber forasteiros, Rosa passara um café, cujo processo era mais demorado no preparo, e disto tiveram uma conversa que a deixou satisfeita por encontrar outros vindos do sertão. Considerando que Rosa e os forasteiros vieram de um lugar cuja economia era relativamente fechada, o assunto do café se mostrou um acréscimo à socialização destes, uma prática comum entre eles. Sá Rita, por outro lado, ao perguntar sobre as atividades deles na cidade, percebe essa circunstância de modo mais pretensioso, sendo o café não uma cortesia, e sim uma oportunidade de obter informações acerca de futuros fregueses do marido (ÉLIS, 2006, p. 83).

Durante alguns dias ainda falou do pai, das lavouras, dos panos que a mãe tecia no tear. Depois voltou ao ramerrão costumeiro, metida no seu canto, fazendo as coisas que lhe eram determinadas, deitando-se com as galinhas, nos dias normais, e levantando-se com as estrelas do céu. Sempre suja, metida no vestido de algodão cru, tomando banho rarissimamente, dormindo sem lavar os pés, fedendo a suor acre de cavalo pisado, mijando em pé e enxugando as pernas com a saia. Muitas vezes dormia na cozinha, encostada na fornalha, a cabeça do cachorro - Tigre - no colo. (ÉLIS, 2006, p. 83)

Sua ligação com a vida e os costumes roceiros ainda são visíveis em relação ao trabalho e aos animais. Tal conexão é visível também quando, após o jantar, ela tentava reunir galhos e arbustos para fazer fogueira, com cuja luz e calor preferia dormir, ou ainda quando, diante de uma ventania, "fazia uma cruz com os dedos indicadores, mode espantar o saci: 'Tesconjuro, bicho feio'" (ÉLIS, 2006, p.84). Tais costumes, estranhos à cidade, a fazia crer que

Nutria pela rua um surdo receio, incerto temor de dano ou possível perigo, olhando-a às escondidas, como se olha um bicho feroz ou nojento. Quando chegava à porta ou à janela, o que era muito raro, metia a metade da cara, conservando a outra metade oculta. À igreja ia de noite e lá ocultava-se num canto escuro, bem atrás, debaixo da escada do coro, de parelha com a preta Inácia, que a ensinou a embrulhar-se no xaile, misteriosamente. Para ir, ia calçada de chinelos, mas voltava com eles nos dedos.

Se havia aglomeração na rua, Rosa metia-se pelos fundos dos quintais ou pelos becos, com o intuito de esquivar-se dos grupos de homens. E resmungava (ÉLIS, 2006, p.79).

A cidade, para ela, era um lugar estranho, logradouro do improvável e da desconfiança. 
Sendo geralmente a figura do caipira ${ }^{47}$ discriminada, enquanto símbolo do atraso diante da moderna industrialização (YATSUDA, 2004, p. 104), a personagem-título é caracterizada por sua relação poética com a natureza. Seu comportamento na cozinha sempre fora de uma pessoa bem quieta, o que dava a "impressão de que ela se dissolvia no ambiente" (ÉLIS, 2006, p. 79).

\begin{abstract}
Identificava-se, nesses momentos, de tal forma com a natureza que as rolinhas fogo-apagou que fogo-apagavam no telhado da casa pelas três horas da tarde, desferiam seus vôos curtos e sibilados e vinham pousar na cozinha, para pinicar o arroz que Rosa catava no apá de seda do buriti. E as galinhas se aconchegavam, confiadas, trocando com a mulher aqueles pequenos acordes que elas costumam trocar entre si. Até sanhaço, de seu natural tão arisco, até esses, em pulos elétricos, piavam e triscavam na janela e desciam ao pilão e daí voavam para o terreiro. Tico-ticos também vinham. Mas esses ela enxotava. Era bicho excomungado que ensinou para os judeus adonde Nossa Senhora estava escondida. Quem matasse um tico-tico e passasse o dedo no vão das suas perninhas, haverá de sentir um cabelo as prendendo. Era a peia que Deus botou nele pro resto da vida. Num vê que o bichinho só veve pulando? (ÉLIS, 2006, p. 79)
\end{abstract}

Parecendo que entrava em transe, sentia Rosa, por sua convivência com as aves, que este tempo era a véspera da chuva. Seu sentimento de aflição revela também sua solidão oculta:

Nunca sossego físico poderia dar ideia de tanta força, de tanto movimento: seres suarentos, enovelados em músculos, derrubavam roças com pesados machados; chamas desvairadas devoravam campos e matas; lutas, queixumes amargos de morte, de transes dolorosos de ingratidão e sofrimento ignorados; vozes falando linguagem pesada de feitiços e superstições; muitas murmurações povoavam o silêncio da mulher. (ÉLIS, 2006, p. 80)

Por ver um galho seco, sentia o início das queimadas e previa a chuva em seguida. O estado de Rosa, na verdade, revela uma relação íntima com a natureza que extrapola a mera conexão ou simples reflexo. Diferentemente do conto "Quadra de São José", por exemplo, no qual Bernardo Élis demonstrou o quanto o meio natural do sertão goiano era, na verdade, mais um obstáculo à sobrevivência do homem em ambiente agreste.

\footnotetext{
${ }^{47}$ Sendo alvo de projeções ideológicas ao longo da história nacional, o caipira é personagem típico da formação brasileira. Enid Yatsuda (2004) diz que poucos são os enfoques modernos em torno do caipira, justamente aqueles que consideram sua consciência, sua cultura e sua participação no processo social, apesar da constante exploração (p. 113). Um dos nomes de excelência citados por Yatsuda na ocasião é o de Bernardo Élis.
} 
O trabalho está totalmente associado à relação homem e natureza. Rosa dificilmente compreendia o ofício de seu Reimundo, no que diz respeito à venda, chamando-o de preguiçoso. Assim, diz que

\begin{abstract}
Nessa quadra do ano o povo estava ocupado em ultimar as derrubadas atrasadas, fechar as roças com cercas, aceirar, queimar as derrubadas, fazer alguma planta no pó, atividades que os alongavam do comércio. Se não cuidavam do chão, cuidavam das reses que a seca definhava, da vaca parida ante da lua (ÉLIS, 2006, p. 80-81).
\end{abstract}

Seu Reimundo conversava somente. O café, ao final do conto, embora feito por dona Rita, fora plantado em covas por Rosa, que fora tachada de maluca porque a patroa não a encontrava. As pegadas sujas em direção à esquina refazem o caminho da narrativa, que, após o encontro de Rosa com os forasteiros, fora interrompido várias vezes nos momentos em que estes preparavam a colheita e alimentavam o gado por interferência da chuva, que seguira também a linearidade da narrativa do sertão à cidade. A chuva também fora pressentida por Rosa, em razão de sua conexão com a natureza.

O conto "Rosa" afirma a falta de vínculo com o meio natural expresso nas narrativas contadas por seu Reimundo no momento do jantar, já que os habitantes da urbe vão perdendo os elos com o sertão. Esta correlação se mostra essencial não só a uma narrativa que caracteriza os propósitos estéticoideológicos de Élis enquanto escritor empenhado, mas também dá a ver uma composição literária que expressa a totalidade das relações sociais entre campo e cidade. Contrapondo o elemento rústico tratado hegemonicamente de forma pejorativa, cujas condições de sobrevivência são ignoradas, ao se firmar sobre a essência racional e subalternizante do trabalho durante o processo colonial (YATSUDA, 2004, p. 104) Élis humaniza o campo e o figura de maneira mais autêntica do que a cidade.

Já o conto "A avó, a cidade e o semáforo", foi escrito por Mia Couto em 2004, em contexto posterior à guerra civil moçambicana. Narrado em primeira pessoa, relata a ida à cidade do narrador e de sua avó, a qual se mostrou receosa com as condições desconhecidas do meio social urbano:

Quando ouviu dizer que eu ia à cidade, Vovó Ndzima emitiu as maiores suspeitas:

- E vai ficar na casa de quem?

- Fico no hotel, avó.

- Hotel? Mas é casa de quem? 
Explicar, como? Ainda assim, ensaiei: de ninguém, ora. A velha fermentou nova desconfiança: uma casa de ninguém? tranquilizar.

- Ou melhor, avó: é de quem paga - palavreei, para a

Porém, só agravei - um lugar de quem paga? E que espíritos guardam uma casa como essa? (COUTO, 2009, p. 125).

O desconhecimento do hotel e o deslocamento do campo para a cidade destacam a aldeia, o hotel e o semáforo como espaços essenciais à narrativa, o que realçará a constituição dos próprios personagens.

O narrador, que era professor na comunidade, havia ganhado uma viagem à cidade para participar de um evento. Sua avó ficara incomodada com o destino do neto: onde ele iria dormir e quem iria cozinhar para ele, atividades que, pensando nos costumes de sua aldeia, seriam preparadas por familiares ou pessoas confiáveis, ligados por um laço sanguíneo comum. Diante disto, tomara a decisão de ir junto.

A avó, por se mostrar um personagem mais velho, é importante veículo ancestral da tradição moçambicana, "elemento objectivador das regras mais decisivas que regem a estrutura e a dinâmica dessas sociedades" (LEITE, 2012, p. 110). Seu receio é baseado em seus conhecimentos acerca da tradição e dos mitos africanos, que rompem as barreiras entre o espírito e a vida prática, aqueles sustentados pela figura dos idosos, mas consolidados pela consciência coletiva. $O$ receio da avó também era o do rompimento dos laços do personagem-narrador com a sua terra natal e a sua tradição.

O que se dá ao final do referido conto entretanto, não se mostra somente uma adequação desta tradição à modernidade esperada pela lógica citadina, em termos mais amplos. É também uma denúncia das condições de penúria em que isso ocorria, visto que a avó acaba por morar próxima a um sinal de trânsito que a fascinara, junto a outros mendigos. Ela, entretanto, reconhecera estes como semelhantes e, de algum modo, os incorporara ao seu convívio, devido a suas práticas comuns, apesar de manter seu elo com o passado familiar ancestral, ao mandar uma carta ao narrador-personagem, no final do conto:

Senti luzes me acendendo o rosto ao ler as últimas linhas da carta: "...agora, neto, durmo aqui perto do semáforo. Faz-me bem aquelas luzinhas, amarelas, vermelhas. Quando fecho os olhos até parece que escuto a fogueira, crepitando em nosso velho quintal...". (COUTO, 2009, p. 128-129) 
Um ponto relevante a se considerar, no tocante à socialização da avó em ambiente citadino, é a situação na qual a personagem supera seus limites materiais e culturais, como a distância em relação a sua aldeia e a seus parentes consanguíneos, pela sua harmonização com as práticas sociais urbanas (LEITE, 1997, p. 108). Não só a avó se mostra apta a um ambiente cultural heterogêneo, como também as distinções entre o campo e a cidade moçambicanos ficam evidentes em tais circunstâncias. No momento em que 0 neto deu-se conta da ausência da avó e foi procurá-la, Ndzima se pergunta acerca do lugar que considera ser a sua casa:

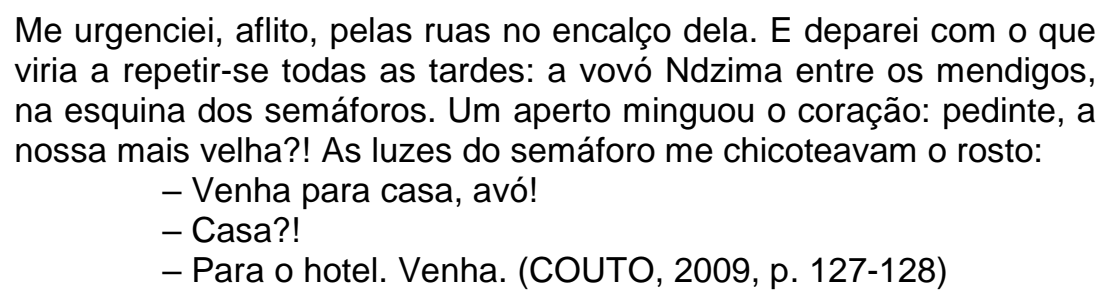

Assim, no trecho supracitado, tanto em relação ao destino da tradição local, bem como no tocante à persistência histórica de um passado ainda reconhecível, há um esforço para se afirmar e se descobrir como integrantes de um projeto nacional moçambicano de modernização, seja pela força do imaginar, seja pela maneira como tais pensamentos perpassam os atores envolvidos no processo.

A partir das indagações da avó feitas ao neto, acerca da cidade, a categoria do trabalho apresenta as seguintes dimensões no conto: o aluguel do espaço do hotel, que não diz respeito a quem mora lá, mas a uma fonte de renda da propriedade. O cozinheiro, cuja atribuição é contestada pela avó, que afirma não ser um serviço e sim "[...] um modo de amar os outros" (COUTO, 2009 , p. 126), assim como quem ajeita a cama do neto; o ato de retirar a água do poço, que não poderia ser do mesmo lugar; a tentativa da avó de transportar galinhas para a cidade.

A percepção dos serviços de forma humanizada, e não racionalizada, é feita pela avó com base na cultura tradicional, que associa a morada com a familiaridade de pessoas com quem pudesse confiar e se identificar, "com nome e história" (COUTO, 2009, p. 126).

A subsistência fundamentada na água como um modo de se reconhecer a geografia local em torno da comunidade, assim como pensar ser 
necessário o transporte de aves pela inexistência de capoeiras, tornam visível a sua relação com a agricultura de subsistência e determinam seu conhecimento de técnicas e acesso à tecnologia.

Comparando-se "A avó, a cidade e o semáforo" com "Rosa", observase que a relação entre o homem e a natureza tem influência de eventos naturais, no caso do último, e dos espíritos, no primeiro. As transformações sociais que distanciam ou aproximam o campo e a cidade, possível pelo movimento dos personagens, fazem Rosa voltar ao seu local de origem e a avó a adaptar-se à miséria citadina. Rosa é prova de que a cultura camponesa nem sempre consegue adaptar-se às relações fragmentadas das cidades, uma vez que suas práticas culturais são desvinculadas do meio social originário e atesta-se uma vez mais a falta de empatia e solidariedade dos entes que circulam pelos aglomerados urbanos ${ }^{48}$.

A avó Ndzima, entretanto, que tinha a família reunida na aldeia em razão da organização formada desde antes da colonização, viu a mesma estrutura social na cidade, simbolizada pelo semáforo, comparando-o à uma luz natural. A história moçambicana ${ }^{49}$ se faz pelo encontro da moderna tecnologia da cidade com a ancestral espiritualidade oriunda das aldeias de uma África mediada pelo processo colonial.

A espiritualidade que rege as sociedades africanas enquanto visão de mundo é mais forte que tais assimetrias entre campo e cidade. Quanto ao uso da tecnologia, o campo é caracterizado como atrasado em Couto e humanizado em Élis, espaço ainda autêntico. Até mesmo em questão ao hibridismo cultural que caracteriza as ficções brasileira e moçambicana contemporâneas, pode-se identificar uma tentativa de figuração positiva do caipira, no caso brasileiro, e de denúncia das condições precárias de vida do campesino deslocado na cidade, no caso moçambicano.

No que tange especificamente aos autores do corpus, o contato assimétrico entre campo e cidade caracteriza o empenho de Élis, ao dar destaque aos migrantes desvalidos do campo. Já a narrativa curta de Couto

\footnotetext{
${ }^{48}$ Isso fora citado no capítulo anterior a respeito não só do livro de contos Veranico de Janeiro (1966), do qual o conto "Rosa" faz parte, mas a respeito do conto "A enxada" especificamente. ${ }_{9}$ Essa é uma característica que rege a obra O fio das missangas (2004), da qual o conto "A avó, a cidade e o semáforo" faz parte.
} 
elege a fronteira como lugar de tensão cultural, ao focalizar uma figura idosa, tradicional e camponesa inconvenientemente habitando a cidade.

$\mathrm{O}$ isolamento que caracteriza ambos os contextos, entretanto, é o que move uma análise de narrativas que problematizam a correlação litoral e sertão, abrangendo a formação história e geográfica de territórios conflituosos.

\section{2. "Amanhã tudo vai começar de novo" 50 : a dialética litoral e sertão}

A ocupação espacial de Brasil e Moçambique é o ponto de partida para uma análise voltada à dialética entre litoral e sertão. Em ambos os casos, esses extremos marcam seu movimento de penetração, o que afetou também seus desníveis econômicos, políticos e sociais. No caso brasileiro, o sertão se traduz como território peculiar à formação literária e nacional, o que caracterizou as diferentes abordagens da particularidade diante do problema do subdesenvolvimento e da colonização. A relação entre os temas e a linguagem é o que impulsiona a transformação da autoconsciência do país (CANDIDO, 2002, p. 87). No caso moçambicano, a leitura de clássicos brasileiros regionalistas como Graciliano Ramos, Jorge Amado e Guimarães Rosa resultou na redefinição de sua literatura, ao se valorizar a moçambicanidade como alteridade em conformação.

Durante o processo colonial, a palavra "sertão" era utilizada para designar a área habitada por aqueles que não acreditavam no mesmo deus e que não eram civilizados (BRAúNA, 2015, p. 63-65). Sem contornos precisos, o litoral e o sertão brasileiros destacam tanto a grandeza do território quanto os núcleos esparsos de contato (PRADO JR., 2011, p. 35). Apesar das várias iniciativas de ocupação ${ }^{51}$, é verificado um grande desequilíbrio entre os dois pelo caráter agrícola do processo colonial, cujas terras litorâneas são mais férteis e somente o comércio pelos rios é mais propício ao interior. Tendo mais

\footnotetext{
${ }^{50}$ Verso extraído do poema "Primeira Chuva", inserido na coletânea de poemas Primeira chuva (1971), de Bernardo Élis.

${ }^{51}$ Caio Prado Jr. (2011) enumera essas iniciativas ao longo da história colonial, tais como as capitanias hereditárias a partir do Tratado de Tordesilhas, onde houve a posse do litoral; o bandeirismo, cuja procura por índios e minérios abriu caminho para o interior do Sudeste (p. 36); a exploração de minas e a fixação de seus núcleos de exploração em Minas Gerais, Goiás e Mato Grosso; as missões católicas da companhia de Jesus ao Norte do Brasil, que possibilitaram a exploração de produtos da floresta; e a presença de rebanhos no sertão do Nordeste, que veio a caracterizar o movimento de ocupação do litoral em direção ao sertão (p. 37).
} 
obstáculos para a internalização, a falta de condições naturais favoráveis ao desenvolvimento humano no interior tornou possível a seguinte definição de Caio Prado Jr (2011): "[...] Onde elas faltam, onde tudo não é posto à disposição dele, o homem está ausente" (p. 42). Em Moçambique, por sua vez, o processo de interiorização também não foi fácil. Inicialmente tendo a presença portuguesa em ilhas ou penínsulas de maior acessibilidade (CABAÇO, 2006, p. 28), sua penetração no interior se deu por casamentos e acordos com chefes locais com interesses na extração de minérios, mas também encontrou resistências (p.31), o que aumentou a importância da missão civilizadora no projeto colonial.

A Conferência de Berlim (1884-1885) oficializou o direito à ocupação efetiva, o que tornou a demanda por alimentos de baixo custo essencial à modernização das nações desenvolvidas (p. 33) e fomentou maior integração das colônias africanas à vida política das metrópoles. O mapa étnico foi associado à estatística entre civilizados e não-civilizados (p. 47-48), a partir do controle da terra e dos colonizados (p. 40). Os negócios com o interior eram feitos a partir das elites mestiças, em associação com as estruturas políticas e sociais tradicionais ( $p .55$ ). Durante o século XIX, ainda, a presença indiana veio a consolidar ligações entre o litoral e o interior, com o comércio de produtos por um frete baixo. A interiorização não é um processo concluído até hoje, persiste como um problema no processo de consolidação da independência de Moçambique, também dificultado pela resistência da RENAMO durante a guerra civil e depois.

A discrepância entre o litoral e o sertão é força simbólica que caracteriza a particularidade brasileira, em vista das estruturas coloniais ainda não superadas e perpetradas pela condição do subdesenvolvimento. "[...] 0 oeste brasileiro contribui para a economia com matéria prima e para a nacionalidade com a pobreza, com tais resultados largamente apresentados na ficção bernardoelisana" (SANTOS, 2004, p. 147). No caso de Élis, temos a particularidade geográfica, histórica e social do estado de Goiás em relação ao resto do país. Em Moçambique, um dos obstáculos históricos que caracterizou a resistência à colonização e também um importante sinônimo de um país que ainda tem muito a descobrir de si mesmo tem a ver com a resistência dos 
povos de regiões distantes. Couto, enquanto biólogo, realizou várias expedições ao interior e veio a tirar vivências que definiram a sua literatura. Esses dados também caracterizaram Moçambique enquanto país plural e segregado a partir das diferenças entre o seu litoral ocidentalizado a sul e seu interior profundo a se descobrir.

O conto "Ontem, como hoje, como amanhã, como depois", escrito por Élis em 1965, trata do movimento e dos desejos de cabo Sulivero, que veio a se relacionar com uma índia trocando-a por cachaça. Sua ação é localizada a no seguinte trecho:

Lesma, cobra, bicho danado que ia deslizando, escorregando, viscoso e frio, lambendo o barranco, mordendo as areias, pastando o capim das estrelas; ora azul como o céu, ora faiscante ao sol de fogo, já imitando o azougue nas noites em que o luar é o próprio silêncio escorrendo; fumaça que se levanta da queimada de mato virgem e se perde na lonjura do horizonte, confundido-se com o céu embaciado de agosto; - para onde iria o Tocantins?

Descia, descia sem nunca parar, engrossava mais ainda, virava mar que banhava o Rio de Janeiro, Bahia e Europa, nem sei quê mais, que aqui a ideia do cabo Sulivero não dava mais e ele baralhava os minguados conhecidos geográficos.

Donde viria o rio? (ÉLIS, 1965, p. 19).

O movimento dos animais, relacionado com o tempo, identifica a região banhada pelo rio Tocantins, cuja origem é indagada. No meio da mata, o rio desagua e se articula a vários eventos naturais: "a se perder no horizonte, sempre igual, sempre igual, como se agora fosse ontem e será amanhã e depois ainda" (ÉLIS, 1965, p. 19).

Um dos moradores desse rio seria o Piratinga, um peixe feroz, que comeu os apetrechos que Chico Piloto tinha consigo antes de cair no rio. A existência de outros bichos, tais como a Cobra Grande e o Negro D'água, é questionada. Ao destacar a figura do rio, bem como assinalar o personagem do cabo Suliveiro, o narrador enuncia o desejo de movimento do militar, do sertão para o litoral e, assim, para a metrópole ocidentalizada. A figura do rio não só evidencia os destinos e as origens de uma história cujo centro é o continente europeu, mas também a jornada do personagem, que "[...] acredita muito mais na existência daqueles seres que nunca viu" (ÉLIS, 1965, p. 20), referindo-se a 
seres místicos como a anaconda ou o negro d'água ${ }^{52}$, próprios da cultura sertaneja.

O personagem cabo Sulivero é, então, apresentado como que crente naquilo que nunca viu. Seu anseio se fazia com a seguinte fala repetitiva:

- Ei, chão parado! - suspirou o cabo como que voltando a si. O rio tinha dessas coisas. Carregava o pobre do cabo nas suas águas lisas, oleosas de mistério, puxando coisa atrás de coisa, jogando lenha na fogueira de sua imaginação. Bastava um isso, para cabo Sulivero montar na garupa do sortilégio e ganhar esse mundão de deus. Não foi assim lá no sul, em Goiânia? (ÉLIS, 1965, p. 20).

Seduzido pelas promessas de riqueza pela extração de diamantes no norte do antigo estado de Goiás, o cabo aceitou transferência para lá, numa cidadezinha junto ao rio Tocantins. Ali, cabo Sulivero se encantou pela filha do chefe da tribo, que ele soubera pelo taberneiro que negociava a filha em troca de cachaça. O taberneiro mediara a negociação com o pai, Man-Pok, declarando o cabo Sulivero como "cristão bão" (p. 22).

A inocência e a ingenuidade de Put-Koe são associadas ao corpo da índia. A menina, cujo nome significa "Esposa do Sol" (p. 23), seria excelente para se levar para o garimpo, de acordo com o pensamento de Sulivero, pois não era exigente como a mulher branca e poderia the servir com os afazeres domésticos e com os préstimos sexuais. Seu pai aceitou que Put-Koe fosse ao garimpo junto de Sulivero pela dose semanal de cachaça.

A distração da menina e do cabo era a de ensiná-la a imitar a continência militar, mas a presença da menina ainda o incomodava:

A menina não conversava nada dessa vida, não contava coisa
alguma, não reclamava, não cantava. Em compensação, também não
trabalhava. Não era capaz de lavar a farda do cabo, nem passá-la.
- Nem cozinhar essa tranca não sabe, - clamava o homem
jururu e desapontado (ÉLIS, 1965, p. 24).

$\mathrm{Na}$ verdade, seu costume era de embrulhar os alimentos em folhas, enterrando-os no chão com uma pedra quente, aquecida numa fogueira. Numa tentativa de ensiná-la a fazer continência, o contato com o corpo da índia o fez

\footnotetext{
${ }^{52}$ Mito menos conhecido, trata-se de um homem negro alto e forte fusionado a um anfíbio que habita os rios da região centro-oeste do Brasil. Ele tem o costume de amedrontar passantes, virar embarcações, partir anzóis de pesca e furar redes. Como prevenção a este ser, os pescadores geralmente atiram uma garrafa de cachaça ao rio para que não tenham sua embarcação destruída.
} 
comparar seus seios a duas peras, diferenciando-os dos das mulheres brancas (ÉLIS, 1965, p. 25). Por fim, a mandou embora.

Man-Pok, entretanto, a touxera de volta, afirmando que "Cristão casou, não pode largar mulher não" (ÉLIS, 1965, p. 26), repetindo várias vezes, indiferente às explicações do cabo, que desconfia ser uma interferência do dono da venda, desejoso pela manutenção de suas vendas. O contato entre os dois resultou na gravidez de Put-Koe e na transmissão de várias doenças, cujos resultados se viam no corpo ferido e purulento dos dois.

[...] Por cima de tudo, havia a imaginação do cabo. O garimpo não dava nada e ele só pensava em sair do lugar, em ir embora, correr mundo, largar o sertão horroroso e morar no Paraná. Porque o Paraná? Foi uma conversa que ouviu, e com ela construiu todo um quadro. O Paraná era um lugar muito rico e muito faturento. Iria para lá" (ÉLIS, 1965, p. 27).

Put-Koe desaparecera, e ele foi morar no povoado próximo ao rio. Lá, ele se pôs a imaginar novamente as terras do litoral.

No povoado, as casinhas pequenas debruçadas sobre o porto frio e profundo. Teria fundo aquele rio? Será que as águas iam eternamente para baixo? As nuvens, o azul, os urubus que o cabo enxergava refletidos dentro d'água, não eram reflexos não; era outro céu que se enxergava através das águas, no fundo misterioso, onde moravam as Cobras Grandes, os Negros d'água, as laras e outras divindades (ÉLIS, 1965, p. 28).

De repente, Sulivero encontra Put-Koe e Man-Pok, que insistira no casamento cristão entre os dois, ao apresentar a filha "igual a moça cristã", limpa e com roupas novas. O ódio do cabo é interrogado:

[...] Seria ódio ao índio, ou ódio de si mesmo, da situação que criara? Será que queria deixar a índia? Coitadinha, tão simples, tão boazinha! Sentia-se enleado, preso por uma teia invisível, sentindo que tudo conspirava para retê-lo às margens daquele rio que passava, passava, e sempre estava presente como uma corrente sem fim, eterna, cansativa, de delírio. [...] Que vontade tinha o militar de conhecer o verdadeiro sentimento de seu coração! (ÉLIS, 1965, p. 29)

Sulivero tentou falar para Put-Koe que fosse embora, pois ele não queria mais saber dela. Ela repetiu o que seu pai falara: "Cristão casou, não pode largar mulher não" (ÉLIS, 1965, p. 30), mas do modo que lhe era próprio. $O$ cabo a ameaçara com um tiro, e ela manteve sua expressão ingênua e sorridente. O tiro viera, alterando com surpresa a sua expressão. "Manso, liso, lá ia escorregando sempre e sempre o rio para o infinito, para o sem fim, ontem, como hoje, como amanhã, como depois e depois ainda" (ÉLIS, 1965, p. 
31-32). Por fim, o vendedor pensou ter escutado um barulho de tiro, mas o reflexo do sol diante do rio o fez constatar que não fora nada.

A presença indígena no conto vem a destacar os fluxos populacionais coesos aos fluxos econômicos de colheita e exportação que caracterizam a formação nacional, o que também passa pela questão étnica. Se as raças negra e indígena traziam problemas culturais complexos a uma formação histórica brasileira de pretensa hegemonia branca, caracterizando assim a composição dos principais centros urbanos litorâneos, o sertão era um refúgio certo a esses marginalizados. A liberdade, conferida pelo afastamento dos principais aglomerados urbanos nacionais, faz com que a lei do mais forte assuma o lugar da luta de classes (PRADO JR., 2011, p. 119).

A miscigenação fez com que todos no sertão viessem a ser confundidos com índios. A pureza de raça era tida não só como sinônimo de ascensão social, mas também de modernidade (PRADO JR., 2011, p. 114116). $O$ isolamento, a pobreza e o atraso que caracterizaram o estado de Goiás tornaram possível uma autogestão político-administrativa excludente que se beneficiava da falta de condições sócio-econômicas (CAMPOS, 2003, p. 24) que pudessem dar alguma autonomia ou caráter político à população. Com tal especificidade foi possível a criação de uma oligarquia que controlava o mandonismo local (CAMPOS, 2003, p. 28), o que propiciou o surgimento do coronelismo no estado.

Apesar da economia quase inexpressiva, os comerciantes são o melhor elo entre os territórios urbanos e rurais ou setores fora do estado, como se provou pela figura do taberneiro no conto estudado. O controle de conflitos, em prol de uma estabilidade política repressora, movida pelos interesses dos grupos oligárquicos hegemônicos, era possível pelo uso abusivo da força; no caso, pelo uso da polícia como aparelho repressivo, o que explica a transferência do cabo Sulivero. Apesar de seu interesse nos diamantes, em razão de um breve lastro do precioso mineral encontrado nas minas da região ao final do século XIX às margens do Tocantins, esse evento efêmero e particular na grande corrente da história brasileira vem ao encontro de um "[...] estado de profunda decomposição econômica e social em que se achava a capitania, cuja riqueza única era o ouro" (PRADO JR., 2011, p. 181). 
Se a modernidade europeia é o que Sulivero almeja, o contraponto se verifica com a mestiçagem e o sincretismo religioso por parte de Pot-Koe e Man-Pok que fazem destacar as posições subalternas encontradas no sertão goiano, um lugar apartado da dita civilização moderna, incluindo aí os reflexos remanescentes da colonização, simbolizados no episódio da busca por diamantes, como um fato próprio da formação histórica brasileira que se repete na mesma frequência anunciada pelo título do conto de Élis. E ainda o embate entre os poderes regional e central que também se junta à divisão de culturas cujo "[...] pequeno rio divide a sensatez do imaginário" (SANTOS, 2004, p. 144). "O conto, portanto, além de ser emblemático quanto ao conflito de culturas, é a metáfora da fronteira entre o subdesenvolvimento 'civilizado' e o subdesenvolvimento adquirido, este por parte da comunidade indígena" (SANTOS, 2004, p. 143).

Por sua vez, o conto "O poente da bandeira", de Mia Couto, trata da morte de um menino por ignorância de um soldado "jurista de chumbo incapaz de distinguir um da lei-de-fora" (COUTO, 2012, p. 53). Tem início com a oração "Aurorava". A falta do acaso é afirmada a partir de um ato corriqueiro em que

[...] As criaturas se vão recortando sob o fundo da inexistência. Neste tempo uterino o mundo é interino. O céu se vai azulando, permeolhável. Abril: sim, deve ser demasiado abril. Agora, que a aurora já entrou neste escrito, entremos nós no assunto" (COUTO, 2012, p. 53)

Um garoto é destacado. "[...] Quem é este menino que faz do mundo outro menino?" (COUTO, 2012, p. 53), mas dele "[...] se engrandece apenas a avó: que o miúdo tem intimidades com o mundo de lá". Seu costume é de pedir à avó que the corte, de forma que assim pode sonhar. "[...] O sangue espontava e o mundo presenciava o futuro, tivesse a barriga prenhe do tempo encostada em seu ouvido" (COUTO, 2012, p. 54).

Ao passar pelo único edifício do município,

[...] seu rosto se ergue para olhar a bandeira. O pano dança dentro do céu, como luz que se enruga. Um velho coqueiro sem copa serve de mastro. As cores do pano estão tão rasgadas que nada nele arcoirisca. Os olhos do miúdo pirilampejam de encontro à luz: é quando o golpe the tombou. Deflagra-se-lhe a cabeça, extracraniana. A voz autoritarista do soldado lhe desce:

-Você não viu a bandeira? (COUTO, 2012, p. 54) 
Apesar de que "[...] um coqueiro Ihe traz lembranças litorais. Onde há uma palmeira sempre deve ser inventado um mar, eternas ondas morrendo" (COUTO, 2009, p. 54), o menino se espanta com a imensidão do céu, e se pergunta: "[...] porquê o chão, tão debaixo dele?". Após outro golpe, sem outra visão que a terra vermelha, "[...] seu pensamento se desarruma. Palmeira, palma do mar, onde o azul espeta suas raízes. Pergunta-se, com as devidas vénias: e se içassem não a bandeira mas a terra?" (COUTO, 2009, p. 54).

Indagado sobre seu respeito em relação à bandeira, o soldado pisa-lhe o rosto, fazendo o menino sangrar. A perda de cores da bandeira e do cenário são indícios da morte do garoto. A bandeira solta-se da palmeira. "[...] No momento, se vê o quanto as bandeiras roubam aos azuis celestiais" (COUTO, 2009, p. 55).

Em seguida, um clarão irrompe e a palmeira desaba sobre o soldado, matando-o. Duas versões sobre o evento são contadas: a primeira, de que a árvore já estava morta. A outra versão, contada pela avó do menino, de maior crença por todos, era a seguinte: "[...] o tronco se desmanchara, líquido, devido à morte daquela criança. Vingança contra as injustiças praticadas contra a vida" (COUTO, 2009, p. 55). A conclusão do conto é:

[...] A palmeira sumiu mas para sempre ficara a sua ausência. Quem passe por aquele lugar escuta ainda o murmúrio das suas folhagens. A palmeira que não está conforta a sombra de um menino, sombra que persiste no sol de qualquer hora (COUTO, 2009, p. 55-56).

A presença do menino é destacada no conto de forma a desenhar a liberdade poética e a sua possível atuação em meio à dureza do mundo ${ }^{53}$. Mesmo distante do litoral, o menino tenta conexão com esse cenário paradisíaco a partir da natureza, pela figura do coqueiro. Tal planta, curiosamente, serve de base à bandeira, um sustentáculo, que apesar de mostrar o domínio do homem sobre a natureza, tem a finalidade de dar suporte ao símbolo maior da nação, ao mesmo tempo denunciando as precárias condições em que esse nacionalismo se manifesta no sertão moçambicano.

\footnotetext{
${ }^{53}$ Sua figura lembra o personagem do menino mais novo do romance brasileiro Vidas Secas (1939), de Graciliano Ramos. O crítico Hermenegildo Bastos (2010) diz, em análise acerca da obra, ao tratar do personagem em questão, que "A imaginação é impedida de se realizar plenamente e, assim, internaliza os limites a ela impostos, passando a incluí-los, mas sem deixar de combatê-los. [...]" (p. 134). Os meninos mais velho e mais novo, juntamente com a cachorra Baleia, são submetidos à comum condição da reificação numa narrativa da luta dos homens pela liberdade num mundo reificado.
} 
O grande obstáculo do menino no conto é a truculência do militar, cuja violência deriva ainda do tempo colonial (BORGES COELHO, 2003, p. 177178). A truculência herdada, entretanto, permaneceu nos movimentos nacionalistas nas estruturas dos aldeiamentos forçados:

[...] teoricamente enquadrados por um agente da polícia europeu, de quem dependia. Porém, aquele na maior parte dos casos, não existia e estes grupos de camponeses mal treinados e armados tinham grande autonomia na função de defesa dos aldeiamentos e de garantia da sua "ordem" interna. (BORGES COELHO, 2003, p. 180)

Além do acesso a recursos e do controle das regras sociais, esses aparelhos militares, em ligação com as estruturas tradicionais de poder, deram origem a novas formas de organização, como as tropas locais e as tropas metropolitanas, consideradas legados do ordem colonial. Um outro tipo de tropa fora criado, dedicada ao caráter regional, racial ou étnico. Tinha caráter mais autônomo e, apesar de ser organizada tardiamente para esse fim, ajudou a estruturar a luta nacionalista (BORGES COELHO, 2003, p. 184) mesmo com assimetrias que resultaram no conflito da guerra civil, como foi tratado no último capítulo.

O enraizamento local, mesmo após a guerra civil, foi bastante destacado nessas resistências militares (BORGES COELHO, 2003, p. 187), e seu potencial de brutalidade tem se refletido até os dias de hoje em jovens oficiais, ao satisfazer seus objetivos ou apropriar-se de recursos (BORGES COELHO, 2003, p. 189) principalmente de origem rural. Por não manisfestar o respeito à bandeira aos seus moldes, o soldado agride brutalmente o menino.

O menino se questiona sobre terem içado não a bandeira, mas a terra, após sua visão ter se deslocado do coqueiro para o céu, do céu para a terra, sob a ação dos golpes do soldado. Esse movimento dos elementos naturais que compõem o litoral, também é uma maneira de pensar a história da interiorização de Moçambique, recorrendo à alegorização da natureza.

A ausência do mar, porém, não é passível de ser inventada/imaginada diante da terra "içada", algo que vai contra o grande desafio: a ex-metrópole portuguesa presentificada pelo enorme oceano. Da imensidão do céu, recuperada pela bandeira livre, entretanto, o tronco parece soltar-se do símbolo que a prende para se emancipar não só do domínio do ente colonial, mas também das forças violentas nacionalistas. $O$ barulho das folhas do coqueiro, 
que mostra ainda uma reintegração com o menino já morto, dá a ver uma grande ligação entre homem e natureza.

As duas versões contadas acerca da morte do oficial tornam-se plausíveis: as pacatas condições do sertão moçambicano apartado do mundo moderno e civilizado, de modo cartesiano, na primeira versão; e as crenças que podem ser associadas a eventos trágicos de origem natural, tornando possível a relação entre homem, natureza e comunidade ${ }^{54}$ (LEITE, 2012, p. 41). Essa tragédia vem a apresentar um país profundamente dividido entre a história e o mito. $\mathrm{O}$ absurdo do sangue do menino, que era cortado pela avó e também fora derramado sobre a terra, necessário ao livre exercício de sonhar, é um recurso já utilizado ${ }^{55}$ por Mia e que se caracteriza "[...] como busca da significação do real e como suporte de uma nova indagação do sentido da existência" (NOA, 2013, p. 97). Isso é bem pertinente considerando o livro em que se insere o conto, Estórias Abensonhadas (1994), que inaugura o tempo de uma nova Moçambique que, após a guerra civil, se permite sonhar. Outro dado muito importante desse livro é a inserção de personagens anônimos, tal como o menino, de modo a registrar a autenticidade da dinâmica da vida do povo moçambicano e a maneira com que os grupos, inclusive os familiares, são atingidos pelas consequências da guerra (NGOMANE, 1999, p. 286).

Comparando-se "Ontem, como hoje, como amanhã, como depois" com "O poente da bandeira", percebe-se uma inclinação dos personagens principais localizados no sertão para com o litoral, um ato de sedução, atração pelo desconhecido. No caso de Sulivero, o desejo é de movimento, motivado pela crença de prosperidade do litoral. No caso do menino, a lembrança do coqueiro. A realização desses desejos, tanto de agitação por parte do cabo, tanto do exercício de sonhar por parte do menino, se dá de diferentes

\footnotetext{
${ }^{54}$ É impossível não lembrar aqui do conto "O dia que explodiu Mabata-bata", do livro Vozes anoitecidas (1986), de Mia Couto. O autor associa a explosão de uma mina no meio rural de Moçambique à crença de um raio que dividiu um boi em mil pedaços. Isso se dá porque a inovação das minas no contexto da guerrilha é confrontada com o tradicionalismo dos povos rurais, como um contraste entre o atraso e a modernização, o passado e o presente do país (LEITE, 2012, p. 45).

${ }^{55}$ Isso aconteceu com o conto "A fogueira", também do livro Vozes anoitecidas, numa situação em que o marido decide cavar uma cova para sua esposa ainda não morta porque perderam a qualidade da existência (NOA, 2013, p. 101). O mesmo pode-se dizer de "Pescador cego", do livro Cada homem é uma raça (1990), que arranca os dois olhos para fisgar peixes com que pudesse se alimentar.
} 
maneiras, sendo que o primeiro não só reifica a índia numa relação de troca, como também se livra dela de modo prático, em nome da sua crença na modernidade e na civilidade ocidental. O segundo precisa sacrificar seu sangue como condição de pagamento pelo exercício do livre sonhar, sendo que seu exercício forçado faz com que a própria natureza interfira nas relações reificadas. A relação com a natureza enquanto obstáculo se mostra forte nos dois casos, alterando ou mantendo uma visão de mundo oriunda dos tempos da colonização, seja pelo isolamento do estado de Goiás no conto de Élis, seja na distância tomada pela a ideologia nacionalista, no tocante às ações truculentas das tropas do interior rural de Moçambique em comparação com o litoral urbano. Verifica-se, assim, um caráter mais mítico presente nas relações entre litoral e sertão em Moçambique, mesmo com o isolamento do interior, em convivência com a história processual e racionalista; e a manutenção de velhas estruturas sociais, no caso brasileiro, que faz do sertão um lugar abandonado, distante do modo de vida litorâneo, entendido como central e ocidental.

O subdesenvolvimento no conto de Couto é percebido pelos instrumentos utilizados pelo militar para promover o valor nacionalista da bandeira, e também pela utilização do coqueiro como substituto à haste da bandeira. No caso de Élis, a condição relegada como a comunidade indígena sobrevive, bem como a civilidade contraditória que fez com que o cabo matasse a índia, o que explicita uma relação subalternizada. Isso expõe "[...] o extermínio literal do índio na fronteira em que ele estabelece contato cultural com a civilização urbana" (SANTOS, 2004, p. 143).

\section{3. "Sobre o último antigamente a varanda perdura"56: literatura, sociedade e outros cenários}

Diante do exposto, a dialética campo e cidade pode mostrar uma história do desenvolvimento das organizações empregadas pelo homem a partir do trabalho, do poder de posse e mando. A tensão entre o empregador e o empregado, entretanto, ainda é evidente até mesmo nas cidades, embora disfarçada pelo modelo civilizacional das grandes metrópoles. A exploração

\footnotetext{
${ }^{56}$ Estrofe extraída do poema "A varanda do antigamente" do livro Tradutor de chuvas (2011), de Mia Couto.
} 
colonial no Brasil fez surgir, com a estrutura fundiária do latifúndio, um modelo econômico que, apesar da criação de um mercado interno, se mantém dominante em relação às formas de trabalho e produção mesmo com os avanços tecnológicos proporcionados pela modernidade. No caso moçambicano, sociedades tribais em associação com os aparelhos de dominação colonial tornaram possível uma liberdade relativa, apesar da quebra gradual dos valores comunitários associados à monocultura e, por sua vez, ao surgimento das cidades, cujo aparelho estatal-colonial tornou mais eficaz a penetração de capital estrangeiro em terras moçambicanas, mesmo com uma luta pela independência supostamente contra certos ideais ocidentais. Sua elite assimilada e de pensamento ocidental se mantém como consumidora de bens estrangeiros e desinteressada do desenvolvimento nacional, do bem-estar das populações interioranas.

A civilização figurada por Couto no conto "A avó, a cidade e o semáforo" é percebida na manutenção de estruturas sociais oriundas do campo, cujo espaço é tido como sinônimo do atraso, em convivência com uma modernização que aparenta ser democrática, quando não o é. Em Élis, os pontos de encontro entre as culturas rural e citadina ganham destaque ao desenvolver a falta de suporte do projeto modernizador às massas oriundas do campo. O autor preocupa-se com a humanização do campo, um local onde é possível verificar os processos que compõem o trabalho em seu cultivo, produção e transformação no objeto final, percepções esta que resultaram no conto e na personagem "Rosa", que não encontrou realização na cidade.

A dialética litoral e sertão, por sua vez, próprios à particularização das literaturas nacionais de Brasil e Moçambique, também dizem respeito aos processos de ocupação e divisão social patrocinados pela colonização, próprios à formação política, histórica e social de ambos os contextos. Com o isolamento, o Brasil de Élis é caracterizado pela difícil penetração e pouca fertilidade dos solos, territórios ignorados pelos centros decisórios e fadados a uma condição de vida inóspita. Nessa qualidade de "chão parado" tornam-se convenientes os movimentos migratórios para fora desse local de atraso, numa associação ao ideal civilizacional e moderno que o litoral proporcionava, em vista das condições grotescas e contraditórias que se passam no conto 
"Ontem, como hoje, como amanhã, como depois". É o que acontece com a busca pelos diamantes por parte de Sulivero, a troca da índia pela cachaça por parte de Man-Pok, o proveito sexual, a pretensa cristandade do homem branco em relação ao índio e a morte da indígena, em prol da suposta liberdade, longe daquele território subdesenvolvido.

Com o elemento rural o Moçambique de Couto é caracterizado pela miscigenação social e cultural. Hoje, porém, percebe-se um grande desconhecimento do interior de Moçambique em relação aos centros urbanos e litorâneos, distância esta que veio a conceber os diferentes graus de nacionalismo empregados em "O poente da bandeira". A relação com a natureza, que destaca os desnivelamentos do projeto nacional em curso, também abre espaço para o seu protagonismo e questiona a liberdade vigente.

A universalidade das concepções ideológicas acerca de campo e cidade permite que seja possível a inserção das histórias brasileira e moçambicana em âmbito internacional, em vista da experiência colonial comum como tributária do capitalismo mundial. Isso, entretanto, não impede que sejam desveladas contradições nos graus de modernização e participação total nos processos que envolvem o desenvolvimento humano. Esses contrassensos próprios da experiência colonial expõem uma divisão entre litoral e sertão que não se revela somente geográfica, mas também social e econômica diante da experiência modernizadora do capitalismo ocidental. Diferentes concepções acerca de nação e história vêm à tona, revelando os impasses de sociedades ainda presas à lógica empreendida durante o processo colonial que reverbera até os dias de hoje. Essa dificuldade de se distinguir o passado e o presente por meio dos elementos espaciais geraram particularidades propícias ao processo de formação nacional de cada uma dessas nações que tentam ainda se adequar à modernidade, apesar de parecer ter os pés ainda acorrentados a um passado problemático. É nessas invenções narrativas que acontecem os milagres promissores do progresso efetivo de um projeto nacional integrativo. 


\title{
4. "E a voz escorre dolorida num tom evocativo de remorso mordida de desespero milenário e religioso" 57 : literatura e história em movimento
}

\begin{abstract}
Não sou homem de igreja. Não creio e isso me dá uma tristeza. Porque, afinal, tenho em mim a religiosidade exigível a qualquer crente. Sou religioso sem religião. Sofro, afinal, a doença da poesia: sonho lugares em que nunca estive, acredito só no que não se pode provar. E, mesmo se eu hoje rezasse, não saberia o que pedir a Deus. Esse é o meu medo: só os loucos não sabem pedir a Deus [...]. COUTO, Mia. "A velha engolida pela pedra". In: Estórias abensonhadas. São Paulo: Companhia das Letras, 2012. p. 121.
\end{abstract}

${ }^{57}$ Estrofe extraída do poema "Procissão do senhor morto", inserido no livro Primeira chuva (1971), de Bernardo Élis. 
Pensar a figuração da realidade tanto em Moçambique quanto no Brasil é essencial para entender a tentativa de captação de seu caráter total, apesar da fragmentaridade das relações modernas, inclusive do conto enquanto narrativa e reflexo estético da realidade objetiva. Afinal, diz Lukács (1963):

El fundamento de todo conocimiento justo de la realidade, ya se trate de la naturaleza o de la sociedade, es el reconocimiento de la objetividad del mundo exterior, esto es, de su existencia independiente de la conciencia humana (p. 11). ${ }^{58}$

Mesmo que Lukács (1963, p. 13) diga que não se pode apreender o movimento da realidade em sua totalidade, ele afirma ser possível o seu reflexo. A aproximação dessa totalidade é possível igualmente pela problematização dos elementos ligados ao profano e ao sagrado, apesar de que, de acordo com o teórico Mircea Eliade (2010), "o mundo profano na sua totalidade, o Cosmos totalmente dessacralizado, é uma descoberta recente na história do espírito humano" (p. 19, grifo do autor). Afinal,

O homem moderno dessacralizou seu mundo e assumiu uma
existência profana. Para o nosso propósito basta constatar que a
dessacralização caracteriza a experiência total do homem não-
religioso das sociedades modernas, o qual, por essa razão, sente
uma dificuldade cada vez maior em reencontrar as dimensões
existenciais do homem religioso das sociedades arcaicas (ELIADE,
2010, p. 19).

Assim, analisou Eliade as experiências que caracterizam a modernidade, pelo profano e pelo arcaico, em vista do aparato da sacralidade.

A partir do sagrado, verifica-se que

O homem das sociedades arcaicas tem a tendência para viver o mais
possível no sagrado ou muito perto dos objetos consagrados. Essa
tendência é compreensível, pois para os "primitivos", como para o
homem de todas as sociedades pré-modernas, o sagrado equivale ao
poder e, em última análise, a realidade por excelência. O sagrado
está saturado de ser. Potência sagrada quer dizer ao mesmo tempo
realidade, perenidade e eficácia. A oposição sagrado/profano traduz-
se muitas vezes como uma posição entre real e irreal ou pseudo-real
(ELIADE, 2010, p. 18, grifos do autor).

Se o sagrado, expressão do cosmos sacralizado, faz com que seja consagrada uma visão total de realidade, a visão objetiva da realidade, possível pelo declínio da Idade Média, do teocentrismo, e pela ascensão do viés antropocêntrico e, por que não, científico e objetivo, é reconfigurada a

58 "O fundamento de todo conhecimento justo da realidade, tratando-se da natureza ou da sociedade, é o reconhecimento da objetividade do mundo exterior; isto é, de sua existência independente da consciência humana" [tradução nossa]. 
esses moldes e tida como profana. Isso acontece com a separação das visões estética, filosófica, religiosa e científica da totalidade da realidade. O que era sagrado foi reconfigurado ao domínio dos homens em suas organizações, apesar de que seus valores sejam profanos, e não sagrados, como o domínio do capital sugere.

No âmbito do sagrado, entende-se o mito, hoje, como algo histórico, uma vez que se encontra fora de seu domínio total. São eventos narrados

[...] que se verificaram num passado distante e fabuloso. Embora os protagonistas dos mitos sejam geralmente Deuses e Entes Sobrenaturais, enquanto os dos contos são heróis ou animais miraculosos, todos esses personagens têm uma característica em comum: eles não pertencem ao mundo quotidiano (ELIADE, 2013, p.15).

Por isso, o conto, diferente do mito, não altera a condição humana, o que é próprio do caráter da arte, enquanto conformação autônoma diante das diferentes visões de mundo num universo dessacralizado ${ }^{59}$. A configuração com que percebemos o mito hoje também destaca a analogia entre o arcaico e o moderno numa relação em que

\begin{abstract}
Um primitivo poderia dizer: eu sou como sou hoje porque antes de mim houve uma série de eventos. Mas teria de acrescentar imediatamente: eventos que se passaram nos tempos míticos e que, consequentemente, constituem uma história sagrada, porque os personagens do drama não são humanos, mas Entes Sobrenaturais. Mais ainda: ao passo que um homem moderno, embora considerando-se o resultado do curso da História Universal, não se sente obrigado a conhecê-la em sua totalidade, o homem das sociedades arcaicas é obrigado não somente a rememorar a história mítica de sua tribo, mas também a reatualizá-la periodicamente em grande parte. É aqui que encontramos a diferença mais importante entre o homem das sociedades arcaicas e o homem moderno: a irreversibilidade dos acontecimentos que, para este último, é a nota característica da História, não constitui uma evidência para o primeiro (ELIADE, 2013, p.17, grifos do autor).
\end{abstract}

A partir desta nota de cunho ontológico, pretende-se pensar, primeiramente, a relação entre mito e religiosidade, e depois a relação entre razão e loucura, a partir do que é concebido como sagrado e profano. Assim, pode-se perceber as diferentes concepções de mundo vigentes nos contos de Bernardo Élis "Virgem santíssima do quarto de Joana" e "Pai Norato", e nos de Mia Couto, "A velha engolida pela pedra" e "Rosa caramela".

${ }^{59}$ Aqui referimo-nos à arte enquanto entidade autônoma e desvinculada da realidade total, apesar de refleti-la, cuja função prática é inexistente. 


\section{1. "E Irei pelos teus olhos, até o mundo voltar a ter princípio"60: mito e religiosidade em profusão}

A experiência religiosa do mundo faz distinguir a realidade pelas classificações que determinam, ou não, a presença do sagrado. Para tanto, um ponto fixo é erguido para que ocorra a manifestação do sagrado na terra e se torne ponto de contato, o que possibilita a existência dos mitos. Isso também vai distinguir o modo como os homens se organizam em relação ao outro pelo nome de cosmos, o que faz de outrem refém do caos. O momento cosmogônico ocorre quando o sagrado, em sua manifestação a partir do cosmos, em seu intuito fundacional, vem a permitir a comunicação com o sagrado em um mundo dito profano, ou caótico. Sua delimitação de limites faz do sagrado uma verdade absoluta e um modo de compreender o mundo. A partir dessa visão em que o mito impera, a presença do sagrado torna-se

[...] o real por excelência, ao mesmo tempo poder, eficiência, fonte de vida e fecundidade. $O$ desejo do homem religioso de viver no sagrado equivale, de fato, ao seu desejo de se situar na realidade objetiva, de não se deixar paralisar pela relatividade sem fim das experiências puramente subjetivas, de viver num mundo real e eficiente - e não numa ilusão (ELIADE, 2010, p.32).

No mesmo sentido, o profano adquire sentido similar, desde que a religião separou-se do mito e tornou-se autônoma, assim como a realidade, mas cujas formas de organização puderam resultar na divisão do trabalho e, assim, da produção, fazendo com que as organizações dos homens, livres de uma compreensão total de mundo, pudessem atingir níveis de desenvolvimento tais como vilarejos, aldeias, bairros, cidades e metrópoles. Algumas dessas cidades geralmente possuem, em sua organização, relação com o sagrado, como o caso de Jerusalém. Se não o tem em específico, tendem a comportar todas as religiões assim, como acontece com os modos mais modernos de agregar as crenças como valores próprios do indivíduo, atribuindo-se o valor de cosmogônico ao que geralmente devia reproduzir a criação do sagrado, e não reprodução dos meios de produção e acúmulo de capital. Com base nisso, pode-se pensar na história de luta de classes para tratarmos, em seguida, de

\footnotetext{
${ }^{60}$ Verso extraído do poema "Lembrança", inserido no livro Tradutor de chuvas (2011), de Mia Couto.
} 
uma história propriamente do "homem inteiramente". Porém, para que tal aconteça, há de se pensar não a favor do acúmulo, como demanda o sistema capitalista, e sim a favor da desfetichização e humanização de todos os indivíduos.

Em sua concepção moderna e ocidental, a religião é tida como uma crença individual. Antigamente, era elemento que selava a relação do homem para com a natureza, os outros homens e o mundo, nessa visão totalizante que reproduzia a criação em escala microcósmica. Tais momentos geralmente são associados aos mitos, cujas figuras divinas atuam sobre o mundo dos homens e deixam a sua herança. Apesar do modelo clássico aqui almejado, entretanto, considera-se também que se tratava de uma sociedade cuja divisão de classes dependia da escravidão por meio de diversas manifestações. Isso nos faz pensar em outros modos de direcionar o desenvolvimento dos homens a um rumo que não faça uns poucos subirem em detrimento de outros. Para tanto, tais contradições históricas nos apontam um meio para que isto se dê. Se a religião é tida como modo de progresso histórico e individual por muitos grupos das grandes metrópoles aos mais pequenos vilarejos, o mito, em sua natureza estática de eterno retorno, torna possível, a partir de um ato, o regresso do mesmo evento como forma de purificar as relações do homem com o mundo.

O conto "A virgem santíssima do quarto de Joana", escrito por Bernardo Élis, publicado no livro Ermos e Gerais (1944), possui duas partes. A primeira, na cena da personagem do título encontrada por Dedé, ensanguentada junto a um bebê morto, trata de como a família de Dedé, o moço que havia engravidado Joana, tentara esconder as "estripulias" sexuais do filho, casando a moça com o coveiro. Dona Fausta, mãe de Dedé, fez parecer que tal ato fosse tratado como uma forma de gratidão por ter a família cuidando dela, acusando-a também de ser mentirosa.

- Já que você está com a alma suja desse pecado feio, procure ao menos não ofender tanto a Deus com ingratidão, com falso, com mentira. Além de perdida - deu um tapa em sua própria boca, temendo pagar língua, - Deus me perdoe a soberba! Além de perdida, mentirosa, ingrata!

- Saia daí. Vá pedir perdão pra Nossa Senhora! arrematou valente o coronel (ÉLIS, 2006, p.160). 
$\mathrm{O}$ ato de ter se entregado a Dedé é comparado a um ritual, e também ao momento do desenvolvimento de seu corpo, o que a fez pensar no Coveiro, figura diabólica associada às regras e aos preceitos impostos pela vida na cidade. Isso lhe fez lembrar:

[...] Aquela imagem áspera e brutal recordou-lhe sua chegada à cidade. Era pequenina. Por qualquer estripulia diziam que iam chamar o coveiro para pegá-la.

- "O coveiro come menino no sumitério", - contava a preta que lavava roupa para a casa do coronel (ÉLIS, 2006, p.161).

O coronel casou Joana com o coveiro, de nome Bento, prometendo-Ihe casa, roupas, itens de cozinha, e ainda adiantou o pagamento de cinco mil-réis. Após o ato, o coronel pensou, ao acender um cigarro:

- Muito bem pago. Ora: honra nacional. Indústria brasileira falsificada. Essa gente é pra essa gentinha mesmo. Pobre e negro têm honra o quê!

O coveiro saiu muito apreensivo:

- Será que bebo esse cincão hoje, ou guardo um tiquinho pra aminhã? (ÉLIS, 2006, p.163).

Concluiu-se que "Seu Rufo era muito bom e muito correto. Deu tudo que prometera ao Bento e ainda Joana casou de véu, grinalda e com um sapato majestosamente grande. A pança, nem tanto" (p. 164). Bento, por outro lado, só pensava se gastaria tudo em bebida naquele mesmo dia ou guardaria para depois, o que evidencia a sua condição social em vista dos hábitos que ostentava.

A segunda parte é dedicada à convivência de Joana com Bento já casados. Inicialmente, Joana tinha receio de que seu filho fosse alvo do coveiro, que fosse mesmo a figura apresentada na canção de Tutu Calundum. Bento, porém, tinha muito carinho pela criança. Depois, Joana concebera uma nova criança, cujo pai era o próprio coveiro, que se sentira feliz por seu "desejo angustioso de ludibriar a morte e continuar a sofrer e fazer besteiras na face do nosso pequeno planeta" (p. 166). Ela, porém, "se sentia ainda mais vil, mais suja, mais ofendida. Era conspurcação de seus sentimentos maternos, pois 0 primeiro filho nascera em plena plenitude de tudo" (p. 165). "E, envolto nuns trapos sujos, um pedaço de carne, uma criaturinha humana, um monstro asqueroso" (p. 166), numa noite tempestuosa, foi como se deu o nascimento do filho do coveiro. 
Era seu filho. Aquele molambo tenro representava o fracasso de sua última esperança. Inconscientemente, teve alcance de sua grande inutilidade. Sua alma teria o aspecto duro dessas planícies secas, nos dias fumarentos de agosto, onde taras e desequilíbrios hereditários se levantariam em colorações rubras de caraíbas amarelas (ÉLIS, 2006, p.167).

A chuva, ao adquirir aspecto fantasmagórico, revela o filho de Dedé, que "dormia com uma perninha para fora. Rosada, cheia de dobras de gordura" (p. 167). De madrugada, após o parto, ao ouvir o choro do filho de Dedé, Joana sente-se como que num clima de pesadelo que

Fez-lhe lembrar o que ouvira contar tanta vez: que os pagãos, nos dias de Senhora das Candeias, enxergam, no fundo impossível do limbo, uma luz muito fraca que Ihes alumia o caminho da eternidade.

"Não seria uma visão do outro mundo?"

"Seu filho não morrera pagão?" (ÉLIS, 2006, p. 167)

Joana vai ao berço e encontra o marido com a boca ensanguentada, mastigando a carne da coxa da criança. "A cicatriz ria sardonicamente e Joana começou também a rir" (p. 168), mas Joana tornou a amamentá-la, cantando a canção, até os dois desfalecerem:

\author{
Tutu Calundum, \\ Sai detrás do murundum, \\ Vem pegá neném, \\ Qui tá com calundum (p.168).
}

A cena retoma o início do conto, com o doutor Dedé reconhecendo a imagem da Virgem Maria no quarto de Joana, presente desde o início da narrativa. Ele diz ser a crença de que o coveiro comera a perna do menino uma bobagem, fruto da ignorância do povo. Vendo, no cadáver de Joana, "uma moça novinha, com a carne iluminada de luxúria, nuinha nos seus braços" (p.169), mas o narrador acrescenta que "podia ser dez e cinco de um dia lindo, intensamente iluminado pelo sol", o que revela a hipocrisia da tradicional família brasileira embasada no patriarcalismo diante de suas crenças e atos imprudentes, tardiamente acobertados pela sombra de seu poder de mando.

$O$ reconhecimento da imagem também diz respeito à dissociação da história da concepção da Virgem Maria pelo Espírito Santo, de caráter mítico, e a história da concepção de Joana, que deixara de ser virgem em razão de um capricho de Dedé, que contou com a cumplicidade de sua família ao forjarem para a pobre mulher um casamento falso. 
Usado como uma canção de ninar, o Tutu Calundum tem o efeito de fazer o bebê adormecer, mas no sono eterno, "com os anjinhos como ele" (COELHO, 1998, p. 95). Associado à angústia infantil, o Tutu "é considerado pelas crianças como um animal informe e negro" (COELHO, 1998, p. 95) dessas cantigas, mas também assume as formas de pessoas extremamente más, como os poderosos que sempre saem ganhando, no caso do conto de Bernardo Élis. Se a palavra "Tutu" tem sua origem no idioma quimbundo, de raiz angolana, verifica-se a sua presença nas diversas regiões rurais do Brasil, sob diferentes nomes. Luiz Gonzaga Marchezan reconhece que

[...] o poder, o poder do poder, o traço do poder que desumaniza havia migrado do coronel para o seu filho, e que o filho daria continuidade para a ação truculenta de um dado tempo.

Nos ermos e gerais, o destino do homem é conduzido ou pelo poder do coronelismo ou pelo poder do acaso, do imprevisível, do que, paradoxalmente, não se prende a um domínio lógico, mas que condiciona uma situação e regula o valor de um comportamento. O imprevisível, nos ermos geralistas, muitas vezes, adquire comicidade, burla o esperado e mostra o homem diante do ridículo, do espetáculo (MARCHEZAN, 2006, p. XIX).

E esse sentimento de burlesco é perceptível, comparando-se as relações parentais entre o coveiro (Tutu Calundum) e seu filho recém-nascido com o coronel Rufo e o doutor Dedé, situando as bases do coronelismo num período de abandono do centro do país em relação ao litoral europeizado, concluindo Marchezan que

Os ermos e os gerais representam regiões afastas dos centros de decisões; neles, por isso, sobrepõe-se um tempo, que é tematizado pelo ficcionista em histórias de heróis sem domínio do seu querer, alheiados, apartados do mundo, do desejo (MARCHEZAN, p. XVII).

Sendo assim, até mesmo as crenças se fazem um meio de sobrevivência para as pessoas humildes, sendo tal prática, a do catolicismo popular, advinda da conduta do catolicismo medieval português e das religiosidades indígena e africana. De certo, há um distanciamento histórico, adaptado ao sertanismo goiano de tais classes não-privilegiadas, refletido na condição de Joana enquanto agregada da família do coronel e em sua crença. A imagem da virgem de seu leito acompanhou a inocência de sua relação com Dedé, a desilusão desencadeada pela família do homem que a engravidara, o descrédito face às condições de classe que impediam a união formal dos dois. $\mathrm{E}$, assim, o casamento forjado com o coveiro, a morte da personagem e, 
finalmente, o momento em que Dedé é tido como da mesma estirpe social e moral que seu pai.

O conto "A velha engolida pela pedra", de Mia Couto, tem seu início marcado pelo narrador, ao evidenciar a posição do autor/artista:

Não sou homem de igreja. Não creio e isso me dá uma tristeza.
Porque, afinal, tenho em mim a religiosidade exigível a qualquer
crente. Sou religioso sem religião. Sofro, afinal, a doença da poesia:
sonho lugares em que nunca estive, acredito só no que não se pode
provar. E, mesmo se eu hoje rezasse, não saberia o que pedir a
Deus. Esse é o meu medo: só os loucos não sabem o que pedir a
Deus. Ou não se dará o caso de Deus ter perdido a fé nos homens?
Enfim, meu gosto de visitar as igrejas vem apenas da tranquilidade
desses lugarinhos côncavos, cheios de sombras sossegadas. Lá eu
sei respirar. Fora fica o mundo e suas desacudidas misérias (COUTO,
2012, p. 121).

A religiosidade do narrador, em sua sacralidade, é vislumbrada pelo viés estético, e a concentração da religiosidade nas igrejas é vista por ele como uma válvula de escape das misérias da vida lá fora. Seu medo, o de não saber lidar com a presença divina e, por isso, ser confundido com um louco, é um ponto importante a ser tratado depois. Mas a declaração do narrador é importante para demarcar suas crenças e seu ponto de vista em relação à religiosidade, o que o leva ao evento narrado: trata-se de um acontecimento ocorrido em uma de suas visitas a uma igreja que, segundo ele, "era de pedra crua, dessa pedra tão idosa como a terra. Nem parecia obra de humano traço" (COUTO, 2012, p. 121). As ações do autor e do divino são, inevitavelmente, comparadas. Das figuras de santos, "madeiras com alma de se crer" (COUTO, 2012, p. 121), ele escuta ruídos que o levam a se aproximar de uma velha pequenina encoberta por uma coluna. A senhora, que estava em posição de oração, pediu para que a ajudasse a se levantar.

Nem uma carne nela se moveu. A velha não conseguia desajoelharse. A rótula dela estava colada no chão, ela não podia se levantar. $E$ me pedia socorro de força e descarrego. Logo a mim que sofro dos ossos, reumasmático (COUTO, 2012, p. 122).

Sem saber o que fazer, ele se ajoelha ao lado dela, e ela diz:

- Vá, me ajude, me empurre deste chão. Depresse-se, moço, que já estou ficando pedra.

Voltei a ajeitar as mãos no corpo dela. Era um peso sem vida, com mais gravidade que um planeta.

- Não rodilhe meu vestidinho. Isso veio das calamidades, fui dada esta roupita com os padres (COUTO, 2012, p. 122). 
A origem de suas vestes, "com os padres", reflete a natureza social da igreja, assim como, quando o personagem-narrador tenta buscar ajuda no lado de fora da igreja, no momento em que a mulher o segurou nas mãos, apesar de imóvel, para impedir que ele fosse lá fora. Ouviram um som da porta da igreja se fechando, como que prendendo os personagens. O personagemnarrador tentara arrombar e gritar, mas em vão. A senhora disse que "era pecado mais que mortal machucar a casa de Deus" (COUTO, 2012, p. 123). O narrador, então, dirigindo-se à ela, responde que seus atos são para que saiam, não para que fiquem presos. Após desistir, este ouviu a idosa falar-lhe o seguinte:

Sabe, meu filho, sabe o que estive a pedir a Deus? Estive a pedir que me levasse, minha palhota lá em cima já está pronta. E eu aqui já me custo tanto! Problema é eu já não tenho corpo para ir sozinha para o céu. Estou tão velha, tão cansadíssima que não aguento subir todos esses caminhos até lá, nos aléns. Pedi sabe o quê? Pedi que me vertesse em pássaro, desses capazes de compridas voações, desses que viajam até passar os infinitos. É verdade, filho. Esta tarde pedi a Deus que me vertesse em pássaro. $E$ me desse asas só para me levar deste mundo (COUTO, 2012, p. 123-124).

O narrador-personagem dormira durante a fala da velha, "em total cancelamento: na ausência do ruído, dos queixumes e rebuliços da cidade" (COUTO, 2012, p. 124). Foi então que, na manhã seguinte, fora acordado por um sacerdote da igreja, que, ao ser perguntado sobre a velha, retrucou: "Que velha?", percebendo que não estava mais lá. O padre o enxotou para fora de modo a pedir-lhe que "não voltasse a usar indevidamente o sagrado daquele lugar" (COUTO, 2012, p. 124). Essa atitude do padre revela uma função prática do elemento sagrado ${ }^{61}$, que fora profanizado em decorrência das relações com o capital e com a dominância de outrem. O narrador-personagem saiu, ficando cego pela claridade do mundo exterior, e em seguida tem a visão da mulher transformada em ave, que diz:

Não, eu não vou a nenhum lado. Foi mentira esse pedido que eu fiz a Deus. Aldrabei-lhe bem. Eu não quero subir para lá, para as eternidades. Eu quero ser pássaro é para voar a vida. Eu quero viajar é neste mundo. E este mundo, meu filho, é coisa para não se deixar por nada neste mundo (COUTO, 2012, p. 124).

Observa-se uma reconfiguração do passado que, antes havia paralisado a mulher, em razão dos seus costumes e cultos, mas que, após ter

${ }^{61}$ Refere-se aqui à mercantilização do sagrado. 
seu pedido real atendido, transfigurou-Ihe em pássaro, vida móvel, como se a vida fosse tida em ciclo, como de fato se faz o tempo africano, conforme sugere Ana Claudia da Silva (2010, p. 161) em sua análise acerca do conto "Nas águas do tempo" de Mia Couto. Ou seja, o culto à vida é o valor essencial ligado à religiosidade moçambicana, em detrimento à procura pela salvação $\mathrm{e}$ pela vida eterna imposta pela doutrina estrangeira e ocidental, de ação historicamente colonizadora. Ainda, o momento de cegueira, ao sair da igreja, é comparado ao famoso mito da caverna de Platão, apesar de que, subvertendose a obra de referência, o homem não sai da caverna/igreja por sua vontade, mas porque é expulso pelo padre. As sombras são comparadas à imobilidade da vida regida pelos cultos das instituições, cuja ligação com a vida fora quebrada, mantendo-se na obscuridade e em sua estrutura aparentemente fechada, não pela crença essencial que ligou a prece da mulher à manifestação do sagrado, como visto ao final do conto. Ainda, tendo-se em consideração o artista, em sua declaração inicial, obtém-se o contraponto do lugar tranquilo esperado com o desespero da fiel, que fora registrada em forma similar a uma estátua, e também com a figura do animal, em comparação à forma humana, que dispunha de maior liberdade de movimento, sem falar da última frase do conto, "E levantou vôo em fantásticas alegrias" (COUTO, 2012, p. 124), adjetivação seguida de movimento própria da arte poética, a qual o autor executa como ofício exemplar.

Em ambos os contos, essência e aparência parecem de fato um problema não só de representação, em que a presença do mito e da manifestação do sagrado se mostram, uma vez que Joana, no conto de Bernardo Élis, tentava reproduzir o ato de consumação do amor a partir do sagrado, sem sucesso; mas também um problema que revela o deslocamento de valores entre os polos do sagrado e do profano, pela presença do Tutu Calundum atuante em contraposição à Virgem Maria espectadora; ainda, um problema de classe no qual o sagrado é atribuído aos valores tradicionais de somente um grupo social dominante em detrimento do bem estar coletivo.

A religiosidade é tida em "Virgem santíssimo do quarto de Joana" como um ideal não alcançado por parte de Joana, apesar de se tratar de doutrina ligada ao processo colonizatório em sua interiorização e aculturação. No caso 
de "A velha que virou pedra", o valor mítico é retomado como elemento para religar o homem moçambicano à realidade, tanto no vieses filosófico e estético como no âmbito religioso, apesar da administração da igreja por sujeitos terrenos.

O sagrado e o profano são importantes elementos que trazem à tona a essência e a aparência entre os elementos da fé e da igreja, que acabam revelando a vida contínua entre os elementos naturais e humanos além das estruturas criadas pelo homem ocidental. Os mitos acabam tendo força maior em contexto moçambicano do que em contexto brasileiro. Isso acontece em Moçambique pela conexão com a natureza, e no Brasil pela sua inadequação aos modelos europeus hegemônicos.

\section{2. "Parece haver fantasma de Bandeiras passeando pelas ruas estreitas e sombrias" "62: razão e loucura em tensão}

Ainda sobre o conto "A velha que virou pedra", o narrador-autor, que adentra a igreja, apesar de não demonstrar credo, apresenta assim as dimensões com que se dá o sincretismo religioso em Moçambique. Eduardo Mondlane (1995, p. 62) lembra que a educação no país, vinculada à igreja católica romana, inclusive sob proteção do governo português, até o regime salazarista, fora responsável pelo assimilacionismo projetado pela metrópole. Disse, na época da escrita de Lutar por Moçambique (1976), que "os portugueses acreditam que há maiores possibilidades de um africano se tornar português em todos os sentidos se ele for católico" (MONDLANE, 1995, p. 63), crença esta ligada à defesa do patriotismo pela administração do serviço público em relação à colônia, apesar dos membros desses diferentes grupos muitas vezes possuírem distintas posições ${ }^{63}$. Na verdade, sua função em

\footnotetext{
${ }^{62}$ Versos extraídos do poema "Goiás", inserido no livro Primeira chuva (1971), de Bernardo Élis.

${ }^{63}$ Moldlane (1995) relatou que
}

[...] De tempos a tempos, funcionários superiores do governo colonial fazem declarações públicas contra as missões protestantes, acusando-as de fomentar sentimentos antiportugueses entre a população africana. Ultimamente, na verdade, os missionários protestantes têm sido acusados de serem responsáveis pela ascenção do nacionalismo tanto em Angola como em Moçambique. (p. 63) 
Moçambique simplesmente foi a de produzir mais mão-de-obra ocidentalizada para Portugal. "O sistema foi elaborado de forma a tornar quase impossível ao africano obter uma educação que the dê acesso a algo mais que não seja o trabalho servil" (MONDLANE, 1995, p. 66). A missão dita como "civilizadora", apoiada nas transformações que excluem progressivamente os elementos tradicionais e promovem a

modernização técnico-econômica das periferias das sociedades
industriais, pareciam ter criado as condições necessárias para a
superação rápida da consciência mitológico-religiosa dominante e
assinalar uma transformação social dos povos destas regiões.
(GROMIKO, 1987, p. 5)

Tais colocações, entretanto, fazem dos aspectos religiosos, muito presentes na consciência nacional dos povos africanos, também "uma influência negativa no processo de desenvolvimento socioeconômico das sociedades africanas" (GROMIKO, 1987, p. 6), podendo provocar a desunião, ao se adquirir consciência de uma classe em relação às outras. Daí surgem classificações como 'primitivo', 'pagão' ou 'idolatria', que "por ferirem a dignidade dos africanos e não reflectirem de modo algum, a realidade" (GROMIKO, 1987, p. 13), eram evidência da pluralidade de manifestações do sagrado. "Em outras palavras, quanto mais é religioso tanto mais se insere no real e menos se arrisca a perder-se em ações não-exemplares, 'subjetivas' e, em resumo, aberrantes" (ELIADE, 2010, p. 85-86, grifos do autor). Sua relação com a verdade é circunstância que diz respeito à forma com que encaram 0 mundo, e tudo o que não diz respeito ao mito não é exemplar.

A dessacralização do mundo a partir destas crenças não está vinculada somente ao processo de colonização, mas ao desenvolvimento do sistema capitalista, o que resulta numa racionalização do mundo (IANNI, 2013 p. 145). Assim,

Para que esta racionalização ocorra e desenvolva torna-se indispensável que se modifiquem práticas e ideais, padrões e valores sócio-culturais, transformando-se o imaginário e as atividades de uns e outros. Na medida em que se forma, consolida e expande, o

Tal atitude por parte de uma organização católica não é novidade, uma vez que várias rebeliões indígenas se deram no Brasil em razão dos jesuítas não concordarem com os tratamentos e ordens da coroa portuguesa, resultando em sua expulsão durante as reformas pombalinas. Santa Rita Durão, inclusive, teve de se justificar junto à coroa por uma apologia à cultura local em sua obra Caramuru. Basílio da Gama, entretanto, em sua obra O Uraguai, coloca os indígenas como vítimas controladas pelos mandos dos jesuítas. 
capitalismo pode influenciar, criar, tensionar, modificar, recobrir ou mesmo dissolver outras formas de organização das atividades produtivas e da vida sócio-cultural. (IANNI, 2013, p. 147)

Tal modificação no cosmos, que está relacionada a um mundo caracterizado pela fragmentação da realidade, caracteriza o que chamamos de mundo moderno. A associação entre ética e economia, entre religião e capitalismo, discutida na obra do sociólogo Max Weber, e desenvolvida no âmbito social, concebe os aspectos religiosos que envolvem as sociedades também como impasses geográficos, culturais e históricos (IANNI, 2013, p. 151). A ocidentalização, integrada ao processo de expansão do capitalismo pelo mundo como processo civilizatório, impondo-se sob as mais variadas formas de organização social e burocratizando a vida comum, que é entendida pejorativamente (IANNI, 2013, p. 152-154). O sociólogo brasileiro Octavio lanni (2013) assim declara:

Uma parte fundamental da racionalização da sociedade é
desempenhada pelo direito, pela codificação jurídica das
responsabilidades, normas e procedimentos, estipulando os
parâmetros das ações e relações, das instituições e organizações. A
partir dos princípios da liberdade e igualdade de proprietários,
formalizados no contrato, institucionalizam-se, generalizam-se e
cristalizam-se as condições e possibilidades formais do intercâmbio,
negociação, parlamentação, controvérsia, prêmio e punição.
Independentemente das peculiaridades não apenas sociais,
econômicas e políticas, mas também culturais e civilizatórias, as
tribos, clãs, nacionalidades e nações podem tomar por referência
critérios de racionalidade básica indispensável à interdependência. (p.
156).

O modelo revolucionário e liberal de nação torna-se padrão a ser seguido com base nos moldes franceses, mesmo que inadequados a um país escravocrata como o Brasil durante o século XIX (SCHWARZ, 2012, p. 15). O direito acaba por se tornar universalmente indispensável à sociabilidade no mundo capitalista, uma burocracia atrelada também à organização em estado, cuja prioridade era o lucro dos latifundiários à base do trabalho escravo, do agregado dependente "da autoridade, mais do que da eficácia" (SCHWARZ, 2012, p. 14). Modelos próprios de racionalização do trabalho foram desenvolvidos a partir da experiência colonial, uma prova de que a dependência dos modelos europeus ainda coloca em xeque a vida social formada como resultado da experiência colonial, dando-lhes a alcunha do 
subdesenvolvimento. O que viria a ser a razão e a loucura a partir destes modelos?

O filósofo e historiador francês Michel Foucault (1978) caracteriza a loucura durante o século XVII, apoiado no positivismo das ciências médicas, no que resulta a internação, e também 0 isolamento moral impingido àqueles acometidos pelo castigo divino da lepra (p. 10-13). A falta de sistematização daqueles considerados loucos faz com que haja uma divisão entre aqueles que pertencem à cidade e aqueles que the são estrangeiros (p. 14). Encarado como passageiro, o louco faz de sua presença um exercício que permite estigmatizar

[...] como no passado vícios e defeitos, aproximam-nos todos não mais do que orgulho, não mais da falta de caridade, não mais do esquecimento das virtudes cristãs, mas de uma espécie de grande desatino pelo qual, ao certo, ninguém exatamente é culpável mas que arrasta a todos numa complacência secreta. A denúncia da loucura torna-se a forma geral da crítica. [...] Se a loucura conduz todos a um estado de cegueira onde todos se perdem, o louco, pelo contrário, lembra a cada um sua verdade [...] (FOUCAULT, 1978, p. 19-20).

Até hoje, a presença da loucura na literatura vem a destacar pontos da cultura hegemônica moderna que não compactuam com os ideais éticos e religiosos tradicionais. Seu centro, portanto, são tipos à deriva da sociedade racionalizada, tais como os personagens-título "Rosa Caramela" e "Pai Norato".

O conto "Pai Norato", de Bernardo Élis, diz respeito aos eventos ocorridos quando um homem que vive em meio à natureza selvagem decide morar com o afilhado e sua esposa. Este tem início com o seguinte trecho: "Aos 18 anos pai Norato deu uma facada num rapaz, num adjutório, e abriu o pé no mundo. Nunca mais ninguém botou os olhos em riba dele, afora 0 afilhado" (ÉLIS, 2005, p. 229). Norato optara por morar numa gruta. Como é próprio do sertão goiano, seu meio natural e inóspito garantia-lhe o domínio dos animais, desde que se mantivesse puro dos contatos femininos. Com isso, tinha "um ar asperamente sagrado de profeta e demônio" (ÉLIS, 2005, p. 231). Ele fazia com que anéis perdidos fossem encontrados e animais feridos fossem curados. O protagonista, após ter cometido um crime e encontrado sentido no mundo, se fez uma figura tirada do mito do bom selvagem rousseauniano; ou seja, um habitante dos "tempos fabulosos que precederam a História" (ELIADE, 2000 , p. 31). Esse tipo de mito dá suporte às utopias por mostrar uma humanidade feliz, que escapou dos malefícios da civilização. Este seria o 
homem natural, o verdadeiro primitivo, mantido como tal para caracterizar uma verdadeira civilização pela perfeição do começo (ELIADE, 2000, p. 32-33), como se vê por seus milagres. A criação dessa recordação, por sua parte, é importante como sonho de redescoberta da contemporaneidade ocidental.

Seu afilhado insistira tanto que o padrinho deixasse o mato e fosse morar com ele que, um dia, Norato o havia feito. Ao dormir, recusara o couro de boi, tomou um fumo e

[...] ficava apostando com a fogueira quem apagava primeiro o olhar. $\mathrm{E}$ a fogueira, na noite, tinha a linguagem muda, mas inteligível dos astros. Saíam labaredas que nem cobras, estirando-se pelo chão, fazendo desenhos horríveis nas paredes, no curral. Cansadas de bailar, piscavam os olhos de brasa, refletindo dentro das pupilas duras de pai Norato, e morriam (ÉLIS, 2005, p. 232).

O reflexo dos astros nos olhos do personagem destaca o caráter realista do conto, que muito tem a falar da relação entre o homem e a natureza. Pai Norato, entretanto, se mostrara atraído pela mulher de seu afilhado. "Aquela mulher bulia-lhe com a castidade que há tanto tempo guardava. Rugia no seu inconsciente a fera quase domada, mas pronta sempre para atacar" (ÉLIS, 2005, p. 232). A castidade era a maneira com que mantinha os poderes e, acima de tudo, a sua relação com a vida natural. Ao ter tentado uma primeira vez, decidira ir embora, mas o afilhado o convencera a ficar. Também constatara que seu poderes ainda se mantinham em funcionamento.

Numa segunda parte da narrativa, a descrição de um rio é invocada:

O rio era aquele gatinho manso que passava lambendo graveto, lambendo a pedreira, carregando as folhas secas, no fundo da casa.

$\mathrm{O}$ rio era aquele cantador de viola, em cuja alma se refletiam 0 batuque das estrelas nuas, perdidas no vácuo milenarmente frio do espaço, o verdor do capim, a beleza das manhãs e a tristeza da tarde. Depois ele ia cantando isso de perau em perau, de cachoeira em cachoeira, nos gorgolhões brancacentos das espumas (ÉLIS, 2005, p. 233-234).

A figura do rio, uma incontornável comparação ao dito de Heráclito, vem a caracterizar os eventos seguintes na narrativa, a partir da relação entre essência e natureza em relação direta com o entrecho. A mulher foi ter com Norato, pedindo para que ele parasse com as investidas, apesar da confiança do afilhado. Norato ameaça: "Ocê decede. Do contrário seu fio morre. - O rio lá ia cantando de perau em perau" (ÉLIS, 2005, p. 234). Ela não cedeu. Na noite seca, ele viu as estrelas mudando, como que também anunciando outros 
rumos naturais da história. Na manhã seguinte, o filho do casal amanhecera morto. A mulher acusara e expulsara Norato de sua casa, apesar dele afirmar ter sido uma jararaca. Na estrada, encontra uma cascavel brigando com um pássaro, e em seguida o afilhado, que desmentiu a mulher afirmando que seu padrinho era santo. Ele não voltara, com raiva da mulher. "Aquela mulher estava azucrinando ele. Já tinha amansado tudo quanto era bicho, só ela, a diaba..." (ÉLIS, 2005, p.235) não cedia. Dias depois, fora ver o afilhado, que estranhou a sua ausência. Antes de sair, disfarçadamente, Norato deixou cair um carrapato-estrela em sua calça. No dia seguinte, o afilhado fora encontrado morto, resultado da falsa acusação da mulher. "Sentia no ambiente a presença invisível do marido a defendendo" (ÉLIS, 2005, p. 237). Ela cedeu.

Os rumos da narrativa foram determinados a partir da ameaça de Norato, cujos elementos que regem seus poderes se voltaram contra o próprio, sem ele ter percebido. Ao identificar a causa da morte do bebê e acusar a jararaca, ele comete o verdadeiro pecado do esquecimento (ELIADE, 2000, p. 38); ou seja, ele perde o sentido das origens de seu poder e da sua busca pessoal, o que viria a caracterizar a sua verdade objetiva.

Num outro dia, Pai Norato foi à mata e uma onça o matara. "Veio mansa, ronronando para ser alisada e de supetão, quando o velho a estava alisando, foi aquele pincho" (ÉLIS, 2005, p. 238). Flores e luzes coloridas iluminavam a noite, junto aos olhos do defunto. "Acendiam-se, apagavam-se. E a mata inteira se iluminou - os troncos, os paus podres, as folhas, o solo, os pirilampos, os corós de fogo - tudo ardia numa luz violácea" (ÉLIS, 2005, p. 238). Com isso, o conto termina com a narração da morte de Norato alegorizada na descrição do rio ao início da segunda parte da narrativa. O olhar do personagem se apagando é comparada à sua disputa com o fogo, presente ao início da narrativa, o que revela o predomínio da natureza e da história sobre o homem.

O evento da facada, ocorrido aos dezoito anos do personagem, é um marco de sua história pessoal e também um ato que caracteriza a violência inerente não só ao sertão goiano, mas, em proporções maiores, ao Brasil ${ }^{64}$.

${ }^{64}$ Em entrevista concedida ao pesquisador Benjamin Abdala Junior, ao tratar do isolamento do estado e da falta de liberdade, Élis (1983) destaca:

[...] Eu sempre digo o seguinte: Goiás é um Brasil exagerado em certos aspectos. Por exemplo: se num ponto do Brasil havia 
Isso se dá, no tocante à formação nacional, devido às condições que vieram a caracterizar o sertão brasileiro, conforme explanado anteriomente.

Por outro lado, o conto "Rosa Caramela", de Mia Couto (2013), trata de uma mulher excluída socialmente por seu aspecto físico, mal sabendo os outros que sua loucura era dada por ter sido deixada no altar. A narrativa começa com o seguinte paratexto:

Acendemos paixões no rastilho do próprio coração. O que amamos é
sempre chuva, entre o vôo da nuvem e a prisão do charco. Afinal,
somos caçadores que a si mesmo se azagaiam. No arremesso
certeiro vai sempre um pouco de quem dispara. (p. 11)

Da personagem título, conforme declara o narrador, "dela se sabia quase pouco" (COUTO, 2013, p. 13). Alvo de piadas por ser corcunda, "Ihe chamávamos Rosa Caramela. Era dessa que se põe outro nome. Aquele que tinha, de seu natural, não servia. Rebatizada, parecia mais a jeito de ser no mundo" (COUTO, 2013, p. 13). Sua corcunda era sinônimo da "mistura das raças todas, seu corpo cruzava os muitos continentes" (COUTO, 2013, p. 13), o que leva em consideração a proposta do autor em relação ao livro em que se insere o conto analisado. O que mais assustava, tornando-se inadmissível nela, era o hábito de falar com as estátuas. "Porque a alma que ela punha nessas conversas chegava mesmo a assustar" (p. 14). Sua existência era esquecida durante o dia, mas era reconhecida à noite pelo desenho de sua corcunda, cantando para que as estátuas saíssem da pedra. De seus motivos não se tinha interesse. Conta-se somente que fora noiva mas que ficara abandonada à entrada da igreja. O noivo havia pedido que não houvesse cerimônias, e ela aceitou a contragosto. Esta é uma

História que contam. Tem sumo de verdade? O que parece é que nenhum noivo havia. Ela tirara tudo aquilo de sua ilusão. Inventara-se noiva, Rosita-namorada, Rosita-matrimoniada. Mas se nada não aconteceu, muito foi que the doeu o desfecho. Ela se aleijou na razão. Para sarar as ideias, Ihe internaram. Levaram-Ihe no hospital, nem mais quiseram saber. Rosa não tinha visitas, nunca recebeu remédio de alguma companhia. Ela se condizia sozinha, despovoada. Fez-se irmã das pedras, de tanto nelas encostar. Paredes, chão, teto: só a pedra lhe dava tamanho. Rosa se pousava, com a leveza dos apaixonados, sobre os frios soalhos. A pedra, sua gêmea. (COUTO, 2013, p. 15)

analfabetismo, aqui o analfabetismo era mais abundante; se havia doenças no Brasil, aqui as doenças eram muito mais abundantes; se havia reacionarismo, aqui ele era ainda maior... Isso era uma brincadeira, mas dava certo (p. 8). 
E tal procura fazia com que ela tratasse bem as pedras. Entre a verdade e a ficção sobre a vida de Rosa Caramela, o mito moderno do amor verdadeiro fez com que ela, ao ser largada no altar, tomasse um comportamento considerado inapropriado socialmente, o ato de conversar com as pedras, pois, encontrava nelas a sua medida, já que não se encaixava no ideal romântico de mulher.

Um segundo momento na narrativa ocorre, revelando o olhar de um menino e sua família. O narrador indaga: "Era a loucura da corcunda que fazia voar nossos juízos?" (COUTO, 2013, p. 16). Todos riam dela exceto Juca, o pai do narrador, que disse: "Ninguém vê o cansaço dela, vocês. Sempre a carregar as costas nas costas" (COUTO, 2013, p. 16). Desempregado, ele somente alugava os sapatos. Não podia dispender tanto esforço por problemas cardíacos, por isso era lento em suas ações. A mãe, por outro lado, era sempre muito rápida, inclusive no trabalho. Juca também se fez paradigma que não se encaixa nos moldes do capitalismo moderno, cuja base era uma família patriarcal com um pai trabalhador e uma mãe destinada aos afazeres do lar.

Numa terceira parte da narrativa, ouvem que Rosa Caramela fora presa por proteger uma estátua da demolição, o que interpretaram como veneração a um colonialista. Acusaram-na de saudar o passado, de uma loucura que escondia razões políticas, já que a estátua "[...] era um pé do passado rasteirando o presente. Urgia a circuncisão da estátua para respeito da nação" (COUTO, 2013, p. 18). Fora presa e, em seguida, anistiada. "Sim, saíra. Numa inspeção à cadeia, Ihe deram amnistia. Ela era louca, não tinha crime mais grave" (COUTO, 2013, p. 20). Em seguida, Juca soube por um parente que ela havia ido a um enterro, se despiu no meio de todos e lançou as roupas na cova, acreditando que o morto viria a precisar delas:

- Leva essas roupas, Jawane, te vão fazer falta. Porque tu vais ser pedra, como os outros.

Olhando os presentes, ela ergueu a voz, parecia maior que uma criatura:

- E agora: posso gostar?

Os presentes recuaram, só se escutava a voz da poeira.

- Hein? Deste morto posso gostar! Já não é dos tempos. Ou deste também sou proibida? (COUTO, 2013, p. 21).

$\mathrm{Na}$ última parte da narrativa, também narrada pelo menino, flagra-se a estátua, que estava fora do pedestal. 
[...] O colono tinha as barbas no chão, parecia que era ele mesmo quem tinha descido, por soma de grandes cansaços. Tinham arrancado o monumento mas esqueceram de o retirar, a obra requeria acabamentos. Senti quase pena do barbudo, sujo das pombas, encharcado de poeira. Me acendi ao juízo: estou como a Rosa, pondo sentimento nos pedregulhos? (COUTO, 2013, p. 22).

Vendo Rosa correndo no jardim, ela chegou às escadinhas da casa dele, como se quisesse se transformar em estátua. Porém, foi surpreendida por Juca, que se apresentou como seu noivo. Ele a chamou para ir embora, e os dois se foram.

O fato de Rosa Caramela ter protegido a estátua do colonialista não foi passível de compreensão por parte da população, que a acusou de desrespeitar a nação. A estátua era um marco do passado colonizatório em meio ao presente independente, semelhante à sua loucura, que fora tratada como pior que o crime. $O$ evento do enterro e a vontade de se transformar em estátua são evidências que permitem comparar os elementos da pedra ou da estátua à morte. A ação do foco narrativo, cuja narração tomou aspectos gerais do caso de Rosa Caramela até o seu melhor detalhamento e particularização, torna-se essencial para o entendimento do processo narrativo deste conto. Ao ser empático à estátua do colonialista, o narrador, filho de Juca, revela que a luta pela individualidade num mundo racional é um ato cuja solidariedade não escapa a todos, o que nos permite questionar a loucura que é atribuída a Rosa Caramela. Como a publicação do conto ocorre em meio ao processo de um país pós-independência, assolado pela guerra civil, o que se debate aqui estabelecido é o da inserção dos indivíduos no plano de país proposto pela FRELIMO e as ações tomadas para a adesão dos indivíduos. Sendo pejorativamente alcunhada de corcunda por portar a mistura das raças, atribuise a Rosa também uma distinção nacionalista com base na pureza racial, concepção defendida por boa por parte da população.

Os dois contos dão a ver a exclusão social em diferentes níveis. No caso de Rosa Caramela, nos diferentes níveis de nacionalismo imbricados na concepção da população sobre tal ideologia, níveis que revelam o preconceito e o atraso. No caso de Pai Norato, o isolamento da região e a falta de leis e ética no sertão fazem com que o personagem procure harmonia com a natureza, em detrimento da vida coletiva. São motivos particulares que dão a 
ver características sociais da do mundo sertanejo, o que caracteriza uma dialética entre o sujeito e a sociedade, entre o interno e o externo.

A punição de Norato ocorre pelo capiau se desarmonizar com a natureza, utilizando-a para seus benefícios particulares e imorais. Sua tentativa de reequilíbrio num universo caótico o distingue dos outros, apesar da alcunha divina dada pelo povo. A loucura the é atribuída pelo meio social em que vivia, vislumbrada pelo personagem pelas cores ao final do conto, enquanto lutava contra o seu destino inexorável, após se desligar do meio natural, que voltou a ser uma ameaça para Norato. Rosa Caramela revela a cegueira social por parte da cidade para com uma singular habitante, cujos motivos particulares são atrelados a outro indivíduo com quem recupera equilíbrio, após a desilusão romântica do matrimônio. Com isso, as contradições da formação social brasileira e moçambicana são expostas, como questionamento da ordem aniquiladora vigente, sem necessariamente perspectivar uma mudança substantiva.

\section{3. "Agora, resta um único desfecho: de novo, acordar por dentro" 65}

A demanda histórica pela modernidade e pela racionalização capitalista do mundo fez com que as dimensões de realidade total se tornassem compartimentadas. $\mathrm{O}$ mito ainda persiste em detrimento de outras formas de totalização, apesar de suas manifestações esporádicas. Por outro lado, a religiosidade também encontra seus impedimentos, em razão do surgimento de uma sociedade administrada.

A razão e a loucura atuam de forma a destacar as contradições da modernidade a ser alcançada por contextos ditos periféricos, o que faz segregar aqueles que não se adequam e excluí-los socialmente. A falta de integração entre o meio natural e a falta de compreensão histórica e empática caracterizam os males sofridos no processo de socialização do mundo, num tempo marcado pela competitividade e desprezo pela condição humana.

Essas concepções de mundo, que podem ser associadas aos desígnios divinos e a uma pretensa totalidade de um ordenamento irracional 65 Estrofe extraída do poema "É tarde", inserido no livro Tradutor de chuvas (2011), de Mia
Couto. 
são etapas de um passado dito fantasmagórico, ainda não superado por alguns povos, ou sintomas de uma modernidade inalcançável em termos lógicos, fatores político-econômico e sociais ou, ainda, contradições inerentes aos contextos periféricos examinados: Brasil e Moçambique. 


\title{
"Com lâmina de enxada a palavra fere o tempo: decepa o cordão umbilical do que pode ser um chão nascente" ${ }^{\prime 66}$ : considerações finais
}

\begin{abstract}
Lesma, cobra, bicho danado que ia deslizando, escorregando, viscoso e frio, lambendo o barranco, mordendo as areias, pastando o capim das estrelas; ora azul como o céu, ora faiscante ao sol de fogo, já imitando o azougue nas noites em que o luar é o próprio silêncio escorrendo; fumaça que se levanta da queimada de mato virgem e se perde na lonjura do horizonte, confundindo-se com o céu embaciado de agosto; - para onde iria o Tocantins?

Descia, descia sem nunca parar, engrossava mais ainda, virava mar que banhava o Rio de Janeiro, Bahia e Europa, nem sei quê mais, que aqui a ideia do cabo Sulivero não dava mais e ele baralhava os minguados conhecimentos geográficos.

Donde viria o rio?
\end{abstract}

ÉLIS, Bernardo. "Ontem, como hoje, como amanhã, como depois". In: Caminhos e descaminhos. Goiânia: Livraria Brasil Central, 1965. p.19.

${ }^{66}$ Estrofe retirada do poema "Sementeira", inserido no livro "Tradutor de chuvas" (2011), de Mia Couto. 
Os fluxos hegemônicos de uma experiência colonial comum e ocidentalizante permite-nos ver os caminhos a seguir, diante do mundo moderno em suas implicações político-sociais (ABDALA JR., 2012, p. 37-40). Isso, é claro, diz respeito também às formas literárias.

As principais características do conto dizem respeito à sua extensão, ao seu efeito encantatório, às situações abordadas e ao seu evidente processo de transformação e fusão entre formas tradicionais e modernas. Constatou-se que o conto também está intimamente ligado à formação nacional de ambas as nações aqui abordadas, Brasil e Moçambique. As contradições ligadas ao processo de formação que as compõem, baseadas na experiência comum da colonização portuguesa, permitiram ver as transformações históricas e formais por meio dos contos de Élis e Couto, dando destaque a sua estética realista. Elegeram-se quatro conformações dialéticas, que ganharam relevância no exame das características que envolvem a relação com a história nacional, face a dois fatores majoritários, o espaço e o tempo. A questão espacial permitiu explorar a divisão campo e cidade e a também o par litoral e sertão. A dimensão lógico-simbólica possibilitou compreender a dinâmica mito e religiosidade, assim como razão e loucura.

No que tange ao conflito campo e cidade, ligado às vivências humanas de maneira universal, a experiência citadina é percebida como (in)civilizatória e conivente com a manutenção das estruturas sociais em Moçambique, apesar de uma modernização precária e anti-democrática. Essa modernização é excludente no Brasil, fazendo com que o campo seja espaço desumanizado com as imensas contradições existentes. Em relação à tensão litoral e sertão, ligada à ocupação demográfica e aos recursos naturais disponíveis, tal confluência apresenta profunda relação com a experiência colonial, o que resulta em contrassensos nacionais incrustados na formação social, seja moçambicana ou brasileira, em vista da violência e do anseio ambíguo pela civilização. A particularidade deste último par dá a ver a experiência singular com que a colonização se processou em cada contexto, mas que não exclui os elementos comuns ao par dialético campo e cidade e, também, da conexão nacional desses países com relação ao restante do mundo, em especial à adequação à modernidade do capitalismo ocidental. Por isso, é possível 
perceber o sertão em "Rosa", mas uma divisão entre campo e cidade menos nítida em "Ontem, como hoje, como amanhã, como depois", exceto talvez pelo provincianismo ostensivo. A ausência de litoral em "Rosa" faz com que este seja associado à estrutura citadina interiorana. Em "O poente da bandeira" percebe-se a estrutura de edifício em meio ao sertão, mas não é clara a posição de campo e cidade devido à predominância do elemento rural, constatada pela rusticidade dos dados naturais, face ao nacionalismo que difere os aspectos sertanejo e litorâneo, e talvez rural e citadino. Em "A avó, a cidade e o semáforo", o campo e a cidade são distinguidos pelos costumes de caráter mítico e religioso, mas não se verifica algo que o aproxime da lógica de litoral e sertão.

É possível perceber o campo e a cidade não só em "Rosa" e "A avó, a cidade e o semáforo" pelos aspectos pontuados, mas também em "Virgem santíssima do quarto de Joana", quando a protagonista associa as crenças em torno do Tuntum Calundum com a sua chegada na cidade (ÉLIS, 2006, p.161). Em "A velha engolida pela pedra", a igreja dá a ver uma estrutura citadina, mas não se sabe a sua dimensão, seja provinciana, seja metropolitana. Em "Pai Norato", as distâncias espelham uma estrutura latifundiária, que corresponde a campo, mas também a gruta e matas, locais onde vivia Pai Norato, o que faz pressupor o domínio do sertão bravio. Em "Rosa Caramela", o ambiente é claramente citadino, apesar do provincianismo com que alcunham Rosa Caramela de louca.

A oposição entre o sagrado e o profano por sua vez, permite explorar as conotações lógico-simbólicas das formações nacionais em destaque. Foram escolhidos os pares relativos ao mito e à religiosidade, e também à problemática entre a razão e a loucura. Se o mito e a religiosidade dizem respeito ao sagrado enquanto fonte de crenças e visão totalizante do mundo, a razão e a loucura referem-se à organização moderna do mundo no âmbito do capitalismo ocidental. A permanência do mito é examinada como aspecto totalizante da estrutura social, ou modelo impossível de ser seguido, em razão do (in)civilizador catolicismo e da cultura assimiladora e elitista. Também são aspectos passíveis de conflito com o racionalismo ocidental, em níveis 
econômico e social, que geram excluídos considerados imorais ou adeptos ao ordenamento social vigente.

A religiosidade cristã pode ter contribuído, com sua missão (in)civilizadora, com o processo racionalizante, ao passo que o mito pode ter colaborado na manutenção de estruturas sociais opressivas. Por um lado, a religiosidade de Norato e a loucura de Joana são bons pontos a se pensar sobre esse processo de racionalização e, também, de validação dessas visões de mundo separadas de sua dimensão total. Por outro, a racionalização pode chegar a um patamar de não se isolarem os motivos individuais da conjuntura histórica, como os de Rosa Caramela, ou das crenças que aprisionam e transformam tudo em pedra.

Com relação ao mito e à religiosidade, "Rosa" possui uma relação com a natureza que a aproxima do 'mito do bom selvagem', como Norato, mas em outros termos. Em "A avó, a cidade e o semáforo", ocorre um processo de racionalização da avó na cidade, mas de maneira que mantém a lógica social associada a elementos naturais, um falseamento do natural a partir do social. Sua condição de personagem de cariz ancestral é a marginalização diante das demandas racionais do acúmulo de capital. Em "O poente da bandeira", há uma ligação entre o meio natural e o sangue da criança que dá a ver uma visão mítica de mundo, em oposição à racionalidade da organização teleológica dos homens. Em "Ontem, como hoje, como amanhã, como depois", o elemento religioso não só se mostra sinônimo de civilidade, mas também de catequização e assimilação forçados, de aprofundamento da reificação da índia, que fora trocada por cachaça. Sulivero também tem seu processo de ascensão interrompido pelas distâncias que o separavam do litoral moderno e civilizado.

Todos os contos aqui analisados exploram aspectos que, em tensão dialética, integram-se não só pelo percurso dos autores do corpus, mas também por fatores que destacam a formação nacional de ambos os contextos, brasileiro e moçambicano.

O compromisso autoral é verificado nos contos de Élis, ao destacar o isolamento de Goiás em relação ao restante do Brasil, revelando criteriosamente aspectos da integração nacional carentes de solução, seja no 
campo, no sertão, na cidade ou no litoral. Fatores ainda presentes, resultantes do processo colonizatório, evidenciam o isolamento social, o atraso, que acarretam o surgimento de uma organização social defasada. Nos contos de Couto, por sua vez, ao destacar a transição excludente para a modernidade, seja pela posse dos meios de produção, seja pelo grau de assimilacionismo utilizado para racionalização do mundo e das crenças, há uma permanente tensão entre campo e cidade, litoral e sertão, como era de se esperar num país de origem colonial.

Os contos em questão perspectivam algum tipo de transformação da ordem sócio-histórica em vigor. Em "Rosa" isso é visível ao comparar-se a narrativa de Seu Reimundo e a de Rosa, tornando o personagem um elemento central da narrativa. O mesmo ocorre com "Rosa Caramela", por se tratar de destinos individuais determinados pela ordem comum, seja a organização humana e racional da cidade, seja pelos desígnios nacionalistas e individualistas que fazem perder a especificidade da história particular de cada um. "Pai Norato" segue na mesma ordem, apesar do personagem não ter se mantido fiel aos seus princípios para com o meio natural. Em "A avó, a cidade e o semáforo", "Ontem, como hoje, como amanhã, como depois", "O poente da bandeira", "A virgem santíssima do quarto de Joana" e "A velha engolida pela pedra", há uma predominância de personagens com alto grau de complexidade existencial, seja pelo anonimato, seja pela substantivação comum, seja pelas ações corriqueiras dos personagens ou dos contextos a que se subordinam. $O$ anonimato é dado presente na fiç̧ão miacoutiana, principalmente no que tange ao livro de contos Estórias abensonhadas (1994) em que se inserem "O poente da bandeira" e "A velha engolida pela pedra". Em "Ontem, como hoje, como amanhã, como depois" e "A virgem santíssima do quarto de Joana" há a presença de situações típicas que envolvem ainda a antiga lógica colonial e o subdesenvolvimento que caracterizam não só o Brasil, mas especialmente a região de Goiás. Mesmo com a presença de elementos da crença popular, "A virgem santíssima do quarto de Joana" tem forma narrativa moderna composta pelo retorno a um evento passado, a partir do resultado presente, o que vem a caracterizar a hipocrisia de Dedé. Em "A avó, a cidade e o semáforo", o narrador se faz, no caso da figura do professor, um novo viajante, com 
conhecimento do passado experimentado na convivência com a avó, o que também define o movimento dessa transformação pelos agentes da narrativa. Seja pela exclusão ou pela opressão, caracterizadas na sua dimensão trágica, os desfechos dos contos de Élis aqui apresentados surpreendem por manter a criticidade, sem se render a elementos pitorescos, criando efeitos surpreendentes, a partir de acontecimentos que são preponderantes no sertão goiano. As situações criadas nos contos de Couto, ora absurdas, ora reveladoras de sua natureza social, chamam a atenção para uma realidade dura, mas não incompreensível. Os desenlaces, face a alguns acontecimentos decisivos, acabam por encantar e revelar outras alternativas que não as do mundo racionalista e fetichizado. Constata-se que a obra de Élis se mostra bastante ligada à realidade social pelos aspectos elencados, e a obra de Couto também não deixa de contestar problemas relativos à formação nacional, que ainda ajudam a construir e a problematizar politica e culturalmente.

Distante da simples reprodução etnocentrista de progresso no mundo capitalista, destaca-se aqui a potencialidade das literaturas produzidas por Élis e Couto, de modo que as assimetrias histórico-sociais de Brasil e Moçambique percebidas em seus contos fazem ultrapassar as fronteiras nacionais "[...] e nos permite uma análise ou auto-análise do que temos de comum e de diferente" (ABDALA JR., 2007, p. 49). Esse conhecimento da realidade e da experiência colonial interroga o ponto de vista eurocêntrico em relação ao outro, de maneira que é apresentada uma experiência produzida pelo outro, com o outro e, por meio deste trabalho comparativo, mesmo entre suas diferenças, é identificada uma grande "[...] potencialidade de quem produz conhecimento na periferia" (ABDALA JR., 2012, p. 42), sem se desprender da experiência histórica comum da colonização portuguesa.

Metaforicamente, nosso trabalho pretendeu-se uma corrida contra o dia de Santa Luzia, que "vinha chegando de galope" (ÉLIS, 2006, p. 52). A relação entre tempo e espaço destaca diferentes processos históricos e sociais, da mesma forma com que se vê num caso em "que só na mentira do encantamento a verdade se casa à estória” (COUTO, 2012, p. 47). Não só em relação a Felizbento, é claro, aconteceu tal empenho, mas em várias situações aqui contadas em que se percebe a sintonia dos autores com áreas culturais 
emergentes: o sertão e a savana. A germinação desses dias começa com algumas palavras molhadas, de chuva ou de sangue, que criam e separam, ou fazem reencontrar um sentido humano e histórico, assim como aconteceu no Brasil e em Moçambique, territórios reais e simbólicos de onde surge a fertilidade literária de Bernardo Élis e de Mia Couto. 


\section{Referências bibliográficas}

AFONSO, Maria Fernanda. O conto moçambicano: escritas pós-coloniais. Lisboa: Caminho, 2004.

ARISTÓTELES. Poética. Traduzido por Eudoro de Sousa. Lisboa: Imprensa Nacional - Casa da Moeda, 2010.

AUERBACH, Erich. A novela no início do Renascimento - Itália e França. Traduzido por Tercio Redondo. São Paulo: Cosac Naify, 2013.

ABDALA Jr., Benjamin. Bernardo Élis: seleção de textos, notas, estudos biográfico, histórico e crítico. São Paulo: Abril Educação, 1983.

ABDALA JUNIOR, Benjamin. Literatura, história e política. 2 ed. São Paulo: Ateliê, 2007.

2012.

Literatura comparada e relações comunitárias, hoje. São Paulo: Ateliê,

ANDRADE, Mário Pinto de. "Prefácio". In: CESAIRE, Aimé. Discurso sobre o colonizador. Traduzido por Noémia de Sousa. Lisboa: Sá da Costa, 1978. p. 511.

BASTOS, Hermenegildo. "Inferno, alpercata: trabalho e liberdade em Vidas Secas". In: RAMOS, Graciliano. Vidas secas. 113ä. ed. Rio de Janeiro: Record, 2010. p. 129-138.

BENJAMIN, Walter. "O narrador". In: Magia e técnica, arte e política: ensaios sobre literatura e história da cultura. Traduzido por Sérgio Paulo Rouanet. $8^{\text {a }}$ ed. São Paulo: Brasiliense, 2012. p.213-240.

BORGES COELHO, João Paulo. "Da violência colonial ordenada à ordem póscolonial violenta: sobre um legado das guerras coloniais nas ex-colónias portuguesas", in Lusotopie: Violences et Controle de la Violence au Bresil, en Afrique ET a Goa. Paris: Karthala, 2003, p. 175-193.

BOSI, Alfredo. "Situação e formas do conto brasileiro contemporâneo". In: BOSI, Alfredo (org.). O conto brasileiro contemporâneo. São Paulo: Cultrix, 1977. p.7-22.

BRAÚNA, Dércio. "O sertão brasileiro na savana moçambicana". In: $A$ assombração da história: história, literatura e pensamento pós-colonial. Fortaleza: Deleatur, 2015. p. 59-81.

CABAÇO, José Luís. Moçambique: identidade, colonialismo e libertação. São Paulo: Editora UNESP, 2009. 
CALVINO, Ítalo. Seis propostas para o próximo milênio: lições americanas. Traduzido por Ivo Barroso. São Paulo: Companhia das Letras, 1990.

CAMPOS, Itami. Coronelismo em Goiás. 2ª . ed. Goiânia: Vieira, 2003.

CANDIDO, Antonio. A educação pela noite \& outros ensaios. São Paulo: Ática, 1987.

. Formação da Literatura Brasileira: momentos decisivos. 12a․ ed. Rio de Janeiro/São Paulo: Ouro sobre Azul/FAPESP, 2009.

. Literatura e sociedade: estudos de teoria e história literária. 11a. ed. Rio de Janeiro: Ouro sobre Azul, 2010.

- Parceiros do Rio Bonito: estudos sobre o caipira paulista e a transformação dos seus meios de vida. 11a. ed. Rio de Janeiro: Ouro sobre Azul, 2010.

- Textos de intervenção. Apresentação, seleção e notas por Vinícius Dantas. São Paulo: Duas Cidades/Ed. 34, 2002.

. "Esquema de Machado de Assis". In: Vários escritos. 5a. ed. Rio de Janeiro: Ouro sobre Azul, 2011. p. 15-33.

CAVACAS, Fernanda; CHAVES, Rita; MACEDO, Tania (Orgs.). Mia Couto: um convite à diferença. São Paulo: Humanitas, 2013.

CAVACAS, Fernanda. Mia Couto: um moçambicano que diz Moçambique em Português. Lisboa: Clássica Editora, 2015.

CESAIRE, Aimé. Discurso sobre o colonizador. Prefácio de Mário Pinto de Andrade. Traduzido por Noémia de Sousa. Lisboa: Sá da Costa, 1978.

CHABAL, Patrick. Vozes Africanas: literatura e nacionalidade. Lisboa: Vega, 1994.

CHAVEIRO, Eguimar Felício. "Ver a cidade com o Professor Scarlato: um passeio nas entrelinhas urbanas". In: COSTA, Everaldo Batista; OLIVEIRA, Rafael da Silva (orgs.). As cidades entre o "real" e o imaginário: estudos no Brasil. São Paulo: Expressão Popular, 2011. p.49-65.

CHAVES, Rita. "Missangas em firme fio: o conto em Mia Couto". In: CAVACAS, Fernanda; CHAVES, Rita; MACEDO, Tania (orgs.). Mia Couto: um convite à diferença. São Paulo: Humanitas, 2013. p.237-254.

CHEVRIER, Jacques. "As literaturas africanas no domínio da investigação comparativista". In: BRUNEL, Pierre; CHEVREL, Yves (Org.). Compêndio de literatura comparada. Traduzido por Maria do Rosário Monteiro. Lisboa: Fundação Calouste Gulbekian, 2004. p. 229-261. 
COELHO, Wilna de Jesus. A Oralidade em Bernardo Élis. Goiânia: Kelps, 1998.

CORTÁZAR, Júlio. Valise de Cronocópio. Traduzido por Davi Arriguci Jr. e João Alexandre Barbosa. São Paulo: Perspectiva, 2013.

COUTO, Mia. Pensatempos: textos de opinião. 3ª ed. Lisboa: Caminho, 2005.

. O fio das missangas: contos. São Paulo: Companhia das Letras, 2009.

. Passageiro frequente. $6^{\mathrm{a}} \mathrm{ed}$. Lisboa: Caminho, 2010.

. E se Obama fosse africano? e outras intervenções. São Paulo: Companhia das Letras, 2011.

. Tradutor de chuvas. 3ª ed. Lisboa: Caminho, 2011.

. Estórias abensonhadas. São Paulo: Companhia das Letras, 2012.

A menina sem palavra - histórias de Mia Couto. São Paulo: Boa Companhia, 2013.

2013.

. Cada homem é uma raça: contos. São Paulo: Companhia das Letras,

. Cronicando. 10ª ed. Lisboa: Caminho, 2013.

. Vozes Anoitecidas. São Paulo: Companhia das Letras, 2013.

. Contos do nascer da Terra. São Paulo: Companhia das Letras, 2014.

. Na berma de nenhuma estrada e outros contos. 8ª. ed. Lisboa: Caminho, 2015.

. "O grande prêmio de um escritor é ser único": entrevista. [Julho de 2016]. LITERATAS - Revista moçambicana \& a complexidade da nossa identidade. Entrevista concedida a Nelson Mucandze. Maputo, n. 65, 2016, p. 10-14.

CRAVEIRINHA, José. "Prefácio à edição portuguesa". In: COUTO, Mia. Vozes Anoitecidas. São Paulo: Companhia das Letras, 2013. p. 7-10.

DAVID, Débora Leite. "Contos do nascer da terra". In: CAVACAS, Fernanda; CHAVES, Rita; MACEDO, Tania (orgs.). Mia Couto: um convite à diferença. São Paulo: Humanitas, 2013. p.201-206.

ELIADE, Miercea. Mito e realidade. Traduzido por Pova Civelli. São Paulo: Perspectiva, 2013. 
. Mitos, sonhos e mistérios. Traduzido por Samuel Soares. Lisboa: Edições 70, 2000.

- O sagrado e o profano: a essência das religiões. Traduzido por Rogério Fernandes. 3a ed. São Paulo: Martins Fontes, 2010.

ÉLIS, Bernardo. Caminhos e descaminhos: contos. Goiânia: Livraria Brasil Central, 1965.

. Ermos e gerais (contos goianos). São Paulo: Martins Fontes, 2006.

- Literatura comentada. Seleção de textos, notas, estudos biográfico, histórico e crítico por Benjamin Abdala Junior. São Paulo: Abril Educação, 1983.

. "Literatura e participação": Entrevista. [Julho de 1983]. São Paulo: Literatura comentada. Seleção de textos, notas, estudos biográfico, histórico e crítico por Benjamin Abdala Junior. São Paulo: Abril Educação, 1983. Entrevista concedida a Benjamin Abdala Junior.

- Melhores contos Bernardo Élis. Direção de Edla van Steen. Seleção e prefácio de Gilberto Mendonça Teles. 4ª ed. São Paulo: Global, 2015.

. Primeira chuva. Goiânia: Oriente, 1971.

. Seleta. Org. Gilberto Medonça Teles. Estudo e notas de Evanildo Bechara. Rio de Janeiro: José Olympio, 1974.

Veranico de Janeiro. Goiânia: ICBC, 2006.

FREDERICO, Celso. A arte no mundo dos homens: o intinerário de Lukács. São Paulo: Expressão Popular, 2013.

FREDERICO, Enid Yatsuda. "Literatura e política". In: UNES, Wolney (Org.). Bernardo Élis: vida em obra. Goiânia: AGEPEL/ICBC, 2005. p.121-129.

FRIEDMAN, Norman. O que faz um conto ser curto? Revista USP, São Paulo, n.63, p.219-230, 2004.

FONSECA, Maria Nazareth Soares; CURY, Maria Zilda Ferreira. Mia Couto: espaços ficcionais. Belo Horizonte: Autêntica, 2008.

FOUCAULT, Michel. História da loucura. Traduzida por José Teixeira Coelho Netto. São Paulo: Perspectiva, 1978.

GALVÃO, Walnice Nogueira. "Cinco teses sobre o conto". In: FILHO, Domício Proença (org.). O livro do seminário. São Paulo: LR Editores/Nestlè, 1983. p. 165-172. 
GLEDSON, John. "Os contos de Machado de Assis: o machete e o violoncelo". In: ASSIS, Machado de. Contos: uma antologia. Vol. 1. Seleção, introdução e notas de John Gledson. São Paulo: Companhia das Letras, 1998. p. 15-55.

GROMIKO, Andrei. As religiões da África: tradicionais e sincréticas. Traduzido por G. Mélnikov. Moscou: Edições Progresso, 1987.

HARVEY, David. Cidades rebeldes: do direito à cidade à revolução urbana. Traduzido por Jeferson Camargo. São Paulo: Martins Fontes, 2014.

HOLANDA, Sérgio Buarque. Raízes do Brasil. 26ª ed. São Paulo: Companhia das Letras, 1995.

IANNI, Octavio. Teorias da globalização. 17ª . ed. Rio de Janeiro: Civilização Brasileira, 2013.

JAMESON, Fredric. A virada cultural: reflexões sobre o pós-moderno. Traduzido por Carolina Araújo. Rio de Janeiro: Civilização Brasileira, 2006.

JOLLES, André. Formas simples. Traduzido por Álvaro Cabral. São Paulo: Cultrix, 1976.

LARANJEIRA, Pires. Mia Couto e as literaturas africanas de língua portuguesa. Revista de Filología Románica, II, Madrid, p. 185-205, 2001. Também disponível em: http://revistas.ucm.es/fll/0212999x/articulos/RFRM0101220185A.PDF Acesso em 04 de dezembro de 2016.

LEITE, Ana Mafalda. Oralidades \& escritas pós-coloniais: estudos sobre literaturas africanas. Rio de Janeiro: EdUERJ, 2012.

"A narrativa como invenção da personagem". In: CAVACAS, Fernanda; CHAVES, Rita; MACEDO, Tania (orgs.). Mia Couto: um convite à diferença. São Paulo: Humanitas, 2013. p.183-193.

. "História, viagem, memória e arquivo colonial na narrativa moçambicana". In: PANTOJA, Selma; BERGAMO, Edvaldo; SILVA, Ana Claudia da (orgs.). África contemporânea em cena: perspectivas interdisciplinares. São Paulo: Intermeios, 2014. p. 95-107.

LEITE, Fábio Rubens da Rocha. Valores civilizatórios em sociedades negroafricanas. ÁFRICA: Revista do Centro de Estudos Africanos da USP, São Paulo, v. 18/19, n. 1, p. 103-118, 1997.

LUCAS, Fábio. "O conto no Brasil moderno: 1922-1982". In: Do barroco ao moderno: vozes da literatura brasileira. São Paulo: Ática, 1989. p. 108-154. 
LUKÁCS, Gyorgy. Arte e sociedade: escritos estéticos 1932-1967. Traduzido por. Carlos Nelson Coutinho e José Paulo Netto. Rio de Janeiro: Editora UFRJ, 2011.

. Marxismo e teoria da literatura. Seleção, tradução e apresentação por Carlos Nelson Coutinho. $2^{\underline{a}}$ ed. São Paulo: Expressão Popular, 2010.

- Problemas del Realismo. México-Buenos Aires: Fondo de Cultura Económica, 1966.

MAGAIA, Albino. Moçambique: raízes, identidade, unidade nacional. Análise, comentários e textos escolhidos. Maputo: Ndjira, 2010.

MARCHEZAN, Luiz Gonzaga. "Introdução". In: MARCHEZAN, Luiz Gonzaga (org.). O Conto regionalista: do romantismo ao pré-modernismo. São Paulo: Martins Fontes, 2009. p.IX-XLIII.

. "Introdução". In: ÉLIS, Bernardo. Ermos e gerais (contos goianos). São Paulo: Martins Fontes, 2006. p. IX-XXIX.

MARX, Karl; ENGELS, Friedrich. Manifesto do partido comunista. Traduzido por Marcos Aurélio Nogueira e Leandro Konder. Petrópolis: Vozes, 2011.

MARX, Karl. Manuscritos econômico-filosóficos. Tradução, apresentação e notas por Jesus Ranieri. São Paulo: Boitempo, 2010.

MATUSSE, A. Construção da Imagem de Moçambicanidade em José Craveirinha, Mia Couto e Ungulani Ba Ka Khosa. Maputo: Livraria Universitária - UEM, 1998.

MONDLANE, Eduardo. Lutar por Moçambique. Maputo: Nosso Chão, 1995.

MORAES, Anita Martins Rodrigues de. "A palavra é fumo: algumas notas sobre Estórias Abensonhadas, de Mia Couto". In: CAVACAS, Fernanda; CHAVES, Rita; MACEDO, Tania (Orgs.). Mia Couto: um convite à diferença. São Paulo: Humanitas, 2013. p.195-199.

MOREIRA, Terezinha Taborda. "A identidade moçambicana no ilusório espelho da raça”. In: CAVACAS, Fernanda; CHAVES, Rita; MACEDO, Tania (orgs.). Mia Couto: um convite à diferença. São Paulo: Humanitas, 2013. p.283-300.

NGOMANE, Nataniel. Entre a mágoa e o sonho... nas Estórias Abensonhadas de Mia Couto. Via Atlântica. São Paulo, n. 3, p. 284-289, 1999.

NKRUMAH, Kwame. "Origens das classes em África". In: MAGAIA, Albino. Moçambique: raízes, identidade, unidade nacional. Análise, comentários e textos escolhidos. Maputo: Ndjira, 2010. p. 30-34. 
NOA, Francisco. A escrita infinita: ensaios sobre literatura moçambicana. $2^{2}$. ed. Maputo: Ndjira, 2013.

. Império, mito e miopia: Moçambique como invenção literária. São Paulo: Kapulana, 2015.

. Perto do fragmento, a totalidade: olhares sobre a literatura e o mundo. São Paulo: Kapulana, 2015.

PRADO JR., CAIO. Formação do Brasil contemporâneo: colônia. São Paulo: Companhia das Letras, 2011.

PIGLIA, Ricardo. Formas Breves. Traduzido por José Marcos Mariani de Macedo. São Paulo: Companhia das Letras, 2004.

POE, Edgar Allan. Poemas e ensaios. Traduzido por Oscar Mendes e Milton Amado. São Paulo: Globo, 2009.

RAMOS, Graciliano. Vidas secas. Posfácio de Hermenegildo Bastos. 113ª ed. Rio de Janeiro: Record, 2010.

ROSÁRIO, Lourenço do. "O fio das missangas, de Mia Couto". In: CAVACAS, Fernanda; CHAVES, Rita; MACEDO, Tania (orgs.). Mia Couto: um convite à diferença. São Paulo: Humanitas, 2013. p.223-235.

SAID, Edward. Cultura e Imperialismo. Traduzido por Denise Bottmann. São Paulo: Companhia das Letras, 2011.

SANTOS, Leila Borges Dias. Narrativas mítica, literária, histórica e a busca de sentido no conto de Bernardo Élis, 'A virgem santíssima do quarto de Joana'. Signótica, Goiânia, v. 26, 2014, p.171-191.

SANTOS, Rogério Santana dos. O triunfo do conto: em Hugo de Carvalho Ramos e Bernardo Élis. Tese (Doutorado em Letras) - Faculdade de Filosofia, Letras e Ciências Humanas, Universidade de São Paulo, São Paulo, 2004358 f.

SAÚTE, Nelson (org.). "Prefácio". In: As mãos dos pretos: Antologia do conto moçambicano. 3를. Lisboa: Dom Quixote, 2001. p.13-22.

SCHWARZ, Roberto. Ao vencedor as batatas. 6⿳亠口冋. ed. São Paulo: Duas Cidades/Editora 34, 2012.

SILVA, Ana Claudia da. O rio e a casa: imagens do tempo na ficção de Mia Couto. São Paulo: Editora UNESP/Cultura Acadêmica, 2010.

SILVA, Ana Lúcia da. A revolução de 30 em Goiás. Goiânia: Cânone, 2005. 
SILVA, Rogério Max Canedo. Romance e história em Chegou o governador, de Bernardo Ellis. Goiânia: UFG, 2016.

TELES, Gilberto Medonça. "A síntese su/realista de Bernardo Élis". In: ÉLIS, Bernardo. Melhores contos Bernardo Élis. Direção de Edla van Steen. Seleção e prefácio de Gilberto Mendonça Teles. 4ª ed. São Paulo: Global, 2015. p. 817.

TRIGO, Salvato. "Literatura colonial, literaturas africanas". In: Literaturas africanas de língua portuguesa: compilação das comunicações apresentadas no Colóquio sobre Literaturas dos Países Africanos de Língua Portuguesa em Julho de 1985. Lisboa: Fundação Calouste Gulbenkian, 1987. p.139-157.

UNES, Wolney (Org.). Bernardo Élis: vida em obra. Goiânia: AGEPEL/ICBC, 2005.

VISENTINI, Paulo Fagundes. As revoluções africanas: Angola, Moçambique e Etiópia. São Paulo: Editora UNESP, 2012.

WILLIAMS, Raymond. O campo e a cidade: na história e na literatura. Traduzido por Paulo Henriques Britto. São Paulo: Companhia das Letras, 2011.

XAVIER, Lola Geraldes. Crônicas de Mia Couto: o entregênero Em torno do hibridismo genológico. Forma Breve. Aveiro, n. 8, p.139-151, 2010.

YATSUDA, Enid. "O Caipira e os outros". In: BOSI, Alfredo (Org.). Cultura brasileira: temas e situações. 4a. ed. São Paulo: Ática, 2004. p.103-113. 


\section{ANEXO I \\ ENTREVISTA COM MIA COUTO}

\section{1 - Como você vê a situação do conto nos dias de hoje?}

Mia: Depende de que país falamos. Existem países onde a tradição do conto se mantém viva e a sua publicação em livro é um das áreas mais importantes de intervenção das editoras. E evidente que a publicação de contos depende muito deste fator de mercado. É uma triste constatação mas que corresponde aos ditames que cercam a produção dos escritores. No caso de Moçambique a edição de livros é ainda muito limitada e não é possível fazer uma avaliação comparada da receptividade do conto e do romance ou da poesia.

\section{2 - De onde você tira as suas estórias? Por que é tão importante contá- las?}

Mia: Tiro-as da vida, das pessoas que encontro, das histórias que escuto ou que adivinho nos silêncios da gente. É vital contar essas histórias porque, no fundo, são as histórias que nos conferem uma identidade particular, são elas que nos individualizam como criaturas únicas e singulares.

\section{3 - Considerando o contato com a História, como você percebe a relação} entre o conto e a História do homem moçambicano? E com a história dos homens?

Mia: Existem uma capacidade infinita de produzir versões dos factos. Eu uma vez escrevi que em Moçambique um facto só é verdadeiro depois de ter sido ficcionalizado. Esse é o poder da oralidade. Em todas as nações a oralidade está viva mesmo que não seja reconhecida ou seja relegada como uma sobrevivência do mundo infantil. Mas no caso de Moçambique essa oralidade é absolutamente dominante. E ela vive com confronto com a versão simplificada e ideologizada da História, dessa versão oficial e solene do nosso passado.

\section{4 - Você pensa que pode haver uma relação especial entre o conto e o romance?}

Mia: Sim, existem diferenças no tratamento e velocidade do texto, no modo como o conto se precipita para um final de surpresa, no modo como o conto 
precisa de desenhar personagens com pinceladas rápidas. Há contos que, no entanto, são romances condensados. E há romances que se percebe que foram esticados a partir de um conto

\section{5 - E quanto ao conto em relação à poesia?}

Mia: A poesia não precisa contar uma história. Ela vive de uma linguagem metafórica que pode não ter outro objeto senão a própria invenção poética. A poesia sugere um modo de pensar usando uma outra racionalidade, usando 0 idioma do que não pode ser dito senão através da criação de beleza.

\section{6 - Você se inspira em quem ou no quê ao contar as histórias do conto?}

Mia: Nas vidas ocultas das pessoas, nessa que são soterradas por baixo daquilo que chamamos a "nossa vida".

\section{7 - Como você contaria sua história, o seu percurso, enquanto contista?}

Mia: Comecei a escrever histórias depois da poesia. Eu era e sou um poeta. Até trabalhar como jornalista em meados de década de 70 eu apenas escrevia versos. Mas depois, com o contato com o quotidiano das pessoas, entendi que havia ali um território de sedução a que não podia resistir. E percebi que para contar aquelas histórias eu precisava de fazer recursos à poesia e à reinvenção do idioma português, que é a língua oficial dos moçambicanos mas ainda não é exatamente a sua língua de cultura.

\section{8 - Por que o conto é tão importante para os moçambicanos?}

Mia: Talvez por causa da predominância da oralidade. A sociedade moçambicana vive em histórias, fabrica-se ficcionalmente para ganhar realidade. Existem tradições ancestrais dos contadores de histórias e a narração é um ritual de afirmação permanente dos valores familiares e éticos.

\section{9 - Na sua opinião, por que o conto deveria ser melhor apreciado do que o romance?}

Mia: Não existe comparação possível. 
10 - Qual deve ser a razão do conto ser curto?

Mia: Ninguém disse que o conto deve ter um determinado tamanho.

11 - Você está planejando lançar mais um livro de contos? Conte-nos um pouco.

Mia: Nunca fiz planos sobre o que iria escrever. Neste momento, estou completamente absorvido pela escrita da trilogia. Mas acredito que regressarei mais tarde aos contos.

12 - Qual a estória que você mais gostou de escrever enquanto conto?

Mia: A fogueira. Por me surgiu de um jacto, e não tive que corrigir ou modificar uma única linha. Foi a única vez que isso sucedeu.

13 - Hoje em dia, com os avanços da mídia, você pensa que o conto ainda tem o seu espaço na imprensa?

Mia: O conto só esteve na imprensa por empréstimo, num espaço eventualmente criado de propósito para a escrita literária. Mas cada vez mais esse espaço se torna reduzido, numa lógica de comunicação que aposta na rapidez e no descartável. Acredito que ele possa sobreviver em suplementos culturais de revista ou de edições de fim de semana.

14 - Você disse em uma entrevista para a União de Escritores Angolanos que você não assumia uma obra como um projeto. Neste momento você lança "Sombras da água", continuação da trilogia "As areias do imperador". Se trata de romance histórico, que você disse não saber do que se trata, revelando uma certa insegurança em relação ao gênero, em uma entrevista concedida a Tania Macêdo e Rita Chaves. $O$ que mudou para que este exato momento, em que você está lançando o segundo livro de uma trilogia? O Romance Histórico e a ideia de "projeto" estão intimamente ligados? Você poderia contar um pouco a respeito da trilogia e o porquê de se tratar de um romance histórico?

Mia: Não será exatamente um "romance histórico" mas um romance em diálogo com a História. Esse diálogo tem por intenção dizer a essa História 
oficial que ela não é a única narrativa, que existem outras versões que disputam visibilidade. Moçambique experimenta essa dificuldade de eleger e impor figuras de heróis nacionais que possam servir de mitos fundadores para a nação em construção. Nesta trilogia em procurar desconstruir a versão oficial da epopeia de um desses heróis, o imperador Ngungunyane. Não se trata de uma denúncia de um qualquer estatuto especial de crueldade. Mas os impérios foram sempre feitos à força e com sangue. $O$ que eu pretendo e que se faça ouvir as vozes dos vencidos, junto com a dos vencedores.

15 - O Romance histórico pós-colonial te parece uma demanda importante para as sociedades pós-coloniais; em especial, à sociedade moçambicana?

Mia: Todos os países africanos são de formação recente. Muitos são feitos de muitas nações que se devem encontrar num projeto comum de nação. Esse projeto é geralmente um mecanismo violento com a imposição hegemónica de uma dessas nações, a sua língua, a sua cultura. A literatura pode sugerir diálogos entre essas nações de forma a que essa nova nação nasce de um reencontro das diferentes identidades num projecto comum. E isso implica revisitar os passados múltiplos dessas nações diversas, cada um com a sua narrativa, cada uma com a sua epopeia e os seus heróis.

16 - Em uma entrevista para Carlos Alberto Jr. você diz sobre a necessidade de se falsear a história criando outra para projetar um futuro. O criar é associado ao contar, e o romance é um espaço de figuração da realidade bem flexível para tais questionamentos históricos. Assim, você pensa que o romance e o conto podem ter algo a ver um com o outro? $\mathrm{E}$ quanto ao romance histórico?

Mia: Não sei delinear fronteiras claras entres esses géneros. Nem sei se os escritores se devem ocupar com essas questões. Eles fazem uma história e é essa história que lhes diz se pede o formato de um conto ou de um romance. 